UNIVERSIDADE DE SÃO PAULO

FACULDADE DE FILOSOFIA, CIÊNCIAS E LETRAS DE RIBEIRÃO PRETO DEPARTAMENTO DE EDUCAÇÃO, INFORMAÇÃO E COMUNICAÇÃO PROGRAMA DE PÓS-GRADUAÇÃO EM EDUCAÇÃO

\title{
AUTOS DE TUTELA E CONTRATOS DE SOLDADA PRODUZIDOS DURANTE O (PEQUENO) GOVERNO DA INFÂNCIA EM RIBEIRÃO PRETO (1872-1917)
}




\title{
AUTOS DE TUTELA E CONTRATOS DE SOLDADA PRODUZIDOS DURANTE O (PEQUENO) GOVERNO DA INFÂNCIA EM RIBEIRÃO PRETO (1872-1917)
}

\author{
Versão Corrigida
}

Dissertação apresentada ao Programa de PósGraduação em Educação do Departamento de Educação, Informação e Comunicação da Faculdade de Filosofia, Ciências e Letras de Ribeirão Preto da Universidade de São Paulo como parte das exigências para a obtenção do título de Mestra em Ciências.

Orientador: Prof. Dr. Sérgio César da Fonseca 
Autorizo a reprodução e divulgação total ou parcial deste trabalho, por qualquer meio convencional ou eletrônico, para fins de estudo e pesquisa, desde que citada a fonte.

Magosso, Luciana Bachiega

Autos de tutela e contratos de soldada produzidos durante $o$ (pequeno) governo da infância em Ribeirão Preto (1872-1917). Ribeirão Preto, 2016.

141 p. : il.

Dissertação de Mestrado, apresentada à Faculdade de Filosofia Ciências e Letras de Ribeirão Preto/USP. Programa de Pósgraduação em Educação.

Orientador: Fonseca, Sérgio César da.

1.Infância. 2.Tutela. 3. Ribeirão Preto. 4. História da Educação. 
À minha mãe, Júlia. 


\section{AGRADECIMENTOS}

Muitas pessoas contribuíram para a realização deste trabalho. Primeiramente, agradeço ao meu orientador Prof. Dr. Sérgio César da Fonseca pelo cuidado, generosidade e paciência durante o percurso da pesquisa. Agradeço à Profa. Dra. Alessandra David e ao Prof. Dr. Elmir de Almeida pelas imprescindíveis contribuições ao trabalho realizadas no momento do exame de qualificação deste, uma vez que suas pontuações e sugestões auxiliaram especificamente na caminhada final para escrita do estudo.

Agradeço à Coordenação de Aperfeiçoamento de Pessoal de Nível Superior (CAPES) pela concessão da bolsa de pesquisa, fator indispensável para realização deste estudo.

Agradeço imensamente aos funcionários do Arquivo Público e Histórico de Ribeirão Preto (APHRP) pelo acolhimento e indispensável auxílio e paciência durante o período de coleta de dados para a pesquisa.

Agradeço à Bia e à Débora, colegas de orientação, pelo carinho e paciência com os quais me acolheram durante período de preparação e início do curso de mestrado.

Agradeço à Kelly, querida e amada amiga, pela atenção e auxílio na escrita do resumo em língua estrangeira, como também pelo indispensável apoio durante o percurso realizado desde minha preparação até a finalização do curso de mestrado.

Agradeço às amigas e aos amigos - que sabem muito bem quem são - que se mantiveram por perto quando o tempo nos permitiu. Felizmente, tenho a felicidade em constatar que tenho muitas pessoas queridas que torceram por mim nestes últimos dois anos, sendo tal apoio decisivo para minha continuação no curso de mestrado.

Agradeço meu tio Antônio e minha tia Almerí, meus mentores desde o início de minha preparação para ingressar no curso de mestrado.

Agradeço aos familiares, meu pai, minha madrasta, minha avó, minha irmã, tios e tias, primos e primas, que vibraram comigo no momento em que recebi a notícia de que havia sido aprovada para ingressar no curso de mestrado.

Agradeço minha mãe, Júlia, por ser minha maior e mais importante apoiadora - desde o início de minha graduação -, principalmente nos momentos de desânimo e impaciência, e por não me abandonar nunca, em nenhum momento ou sob qualquer circunstância. 
"Admirava-me que essa gente pudesse viver, lutando contra a fome, contra a moléstia e contra a civilização; que tivesse energia para viver cercada de tantos males, de tantas privações $e$ dificuldades. Não sei que estranha tenacidade a leva a viver $e$ porque essa tenacidade é tanto mais forte quanto mais humilde e miserável”.

(Lima Barreto, "Recordações do escrivão Isaías Caminha”) 


\section{RESUMO}

O trabalho ora apresentado tem como objeto de estudo o cotidiano da infância, principalmente a desvalida, em Ribeirão Preto (SP), entre os anos de 1872 e 1917, a partir das intervenções do discurso jurídico, tendo como fonte de pesquisa os processos judiciais de tutela e soldada produzidos na cidade. A tutela é uma instituição antiga no Brasil e em Portugal, estabelecida desde as primeiras ordenações do reino e preservada como referência doutrinária pela última compilação das leis do Império, as Ordenações Filipinas. No Brasil, antes da tutela se tornar um instituto jurídico ao qual se recorria para reconhecer a criação de crianças consideradas órfãs, tal prática, sem qualquer tipo de regulamentação, era usual há tempos e ainda se mantinha ativa no século XIX, pois respondia ao propósito de cuidar de alguém inspirado pela caridade cristã. Contudo, o interesse em aproveitar o trabalho de outrem era frequente entre as famílias que recebiam crianças desvalidas nesse período. Assim, o instrumento da tutela, utilizado em casos de crianças com posses e em situação de orfandade, passou a ser aplicado, de modo gradual, em crianças desvalidas, tornando-se prática comum na forma de contrato de soldada. Tendo como base as fontes históricas obtidas no Arquivo Público e Histórico de Ribeirão Preto e partindo da referência legislativa às Ordenações Filipinas até a vigência do primeiro Código Civil brasileiro, em 1917, o estudo consiste em elucidar como ressoaram as práticas de tutela e soldada no interior, com vistas a acompanhar a influência e evolução do discurso jurídico da época sob a infância ribeirão-pretana do final do século XIX e início do século XX.

Palavras-chave: Infância. Tutela. Contrato de soldada. Ribeirão Preto (SP). História da Educação. 


\begin{abstract}
The work herein presented aims at the study of the children's daily life, mainly the unprivileged ones, in the city of Ribeirão Preto (SP), between the years of 1872 and 1917, from the interventions of the legal discourse; its research sources are the guardianship and the soldada lawsuits produced in the city. Guardianship is an old institution in Brazil and Portugal, established since the first ordinations of the kingdom and preserved as a doctrinal reference by the last compilation of law of the Empire, the Philippine Ordinations. Before guardianship became a legal institution to which people resorted to recognize raising children considered orphans, such practice had been usual for a long time, without any kind of regulation. It was still kept alive in the $19^{\text {th }}$ century because it answered the purpose of taking care of someone, inspired by the Christian charity. However, interest in harnessing someone else's labor was frequent among families who received underprivileged children at the time. Thus, the guardianship instrument, applied in cases of orphaned children with possessions, was applied gradually for underprivileged children and became common practice in the form of the soldada contract. Based on the historical sources obtained from the Historic Public Archives of Ribeirão Preto, and on the legislative reference to the Philippine Ordinations until the validity of the first Brazilian Civil Code (in 1917), the study consists of elucidating how the practices of guardianship and soldada resounded out of the state capital. It also follows the influence and evolution of the legal discourse at the time, regarding the children of Ribeirão Preto at the end of the $19^{\text {th }}$ and beginning of the $20^{\text {th }}$ centuries.
\end{abstract}

Keywords: Childhood. Guardianship. Soldada contract. Ribeirão Preto (SP). History of Education. 


\section{LISTA DE GRÁFICOS}

Gráfico 1 - Porcentagem da população total de Ribeirão Preto segundo condição social e gênero (1872)

Gráfico 2 - Quantidade de crianças/jovens segundo sexo de acordo com tipo de ação nos processos produzidos entre 1872-1917 46

\section{LISTA DE QUADROS}

Quadro 1 - Simulação do catálogo referente ao Fundo "Processos Antigos" disposto pelo Arquivo Público e Histórico de Ribeirão Preto 41 


\section{LISTA DE TABELAS}

Tabela 1 - População total segundo grupos de idade, sexo e condição social em Ribeirão Preto (1872)

Tabela 2 - População total escrava e livre em Ribeirão Preto (1872 e 1886) 28

Tabela 3 - População total segundo grupos de idade, sexo e cor em Ribeirão Preto (1886) ... 28

Tabela 4 - Média anual de nascimento segundo sexo em Ribeirão Preto (1886)......

Tabela 5 - Total de óbitos segundo sexo, grupos de idade e condição social em Ribeirão Preto (1886)

Tabela 6 - Total de filhos livres de mulheres escravas segundo sexo, matrícula, averbados por motivo de falecimento e renunciados pelo senhor em Ribeirão Preto (1886).

Tabela 7 - População escrava matriculada até 30 de março de 1887 segundo grupos de idade e sexo em Ribeirão Preto

Tabela 8 - Valores de escravos comercializados segundo grupos de idade em Ribeirão Preto (1886)

Tabela 9 - Quantidade de processos por tipo de ação produzidos entre 1872-1917......

Tabela 10 - Quantidade de crianças/jovens segundo sexo e idade/período de vida indicados nos processos por tipo de ação

Tabela 11 - Relação de processos de apreensão em que a idade/período de vida foi indicada 49

Tabela 12 - Relação de processos de contrato de soldada em que a idade/período de vida foi indicada

Tabela 13 - Relação de processos de prestação de contas de soldada em que a idade/período de vida foi indicada.

Tabela 14 - Relação de processos de remoção de tutor em que a idade/período de vida foi indicada

Tabela 15 - Relação de processos de tutela ad hoc em que a idade/período de vida foi indicada

Tabela 16 - Relação de processos de tutela dativa em que a idade/período de vida foi indicada 
Tabela 17 - Relação de processos de tutela legítima em que a idade/período de vida foi indicada

Tabela 18 - Processos em que a cor da criança/jovem foi indicada 53

Tabela 19 - Processos em que a cor da mãe e/ou do pai foi indicada ................................. 54

Tabela 20 - Quantidade de processos encontrados no APHRP no período pré-abolição 55 


\section{SUMÁRIO}

1. INTRODUÇÃO.

2. A PESQUISA COM PROCESSOS JUDICIAIS: O CASO DE RIBEIRÃO PRETO (1872-1917)

2.1 Processos judiciais como fonte de pesquisa: alguns apontamentos .......................... 17

2.2 Sobre a urbe interiorana de Ribeirão Preto: breve histórico e dados demográficos ....... 21

2.2.1 Ribeirão Preto do passado em números ......................................................... 25

2.2.2 O problema da infância nos periódicos ribeirão-pretanos ..................................... 32

2.3 Metodologia e organização dos dados coletados nos processos judiciais ribeirãopretanos (1872-1917).

\section{DO ABANDONO À ASSISTÊNCIA DA INFÂNCIA DESVALIDA:} HISTORIOGRAFIA E LEGISLAÇÃO. 57

3.1 Contextualização sociohistórica das práticas do abandono de crianças e assistência da infância desvalida no Ocidente

3.1.1 Das práticas de abandono e regularização da assistência lusas à possível gênese da assistência à infância desvalida no Brasil

3.2 A legislação e a infância desvalida no Brasil Imperial .............................................. 69

3.3 Observações sobre a infância nos processos judiciais ........................................... 80

4. A INFÂNCIA SOB TUTELA

4.1 Do ato ao auto: o que os processos “contam” sobre a infância e o cotidiano ribeirão-

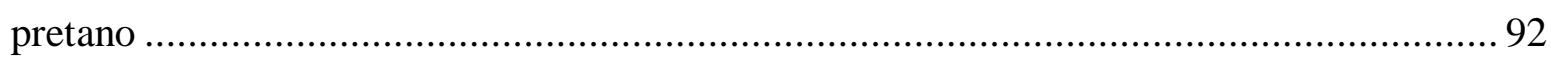

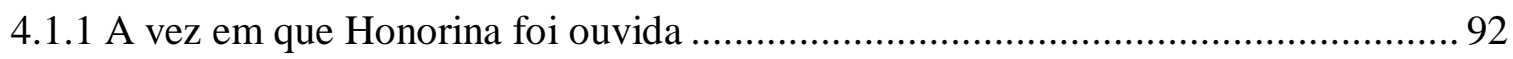

4.1.2 O dia em que Victalina acreditou ser livre ..................................................... 98

4.1.3 O caso de "amor" que se tornou caso de polícia............................................... 101

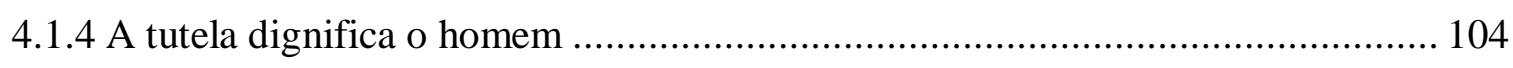

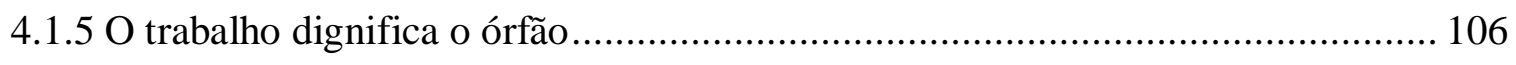

4.1.6 A paradoxal condição feminina ribeirão-pretana: ser mulher e ser mãe pelo/no

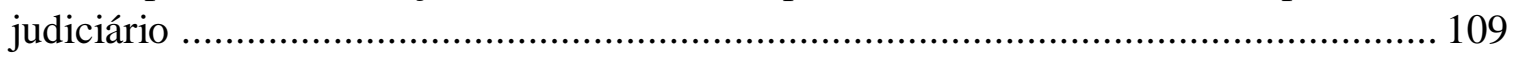

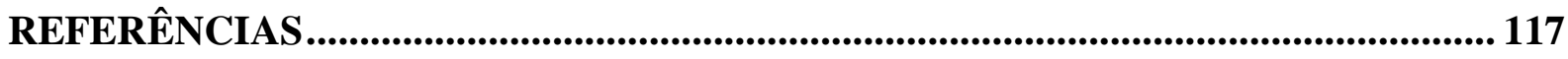

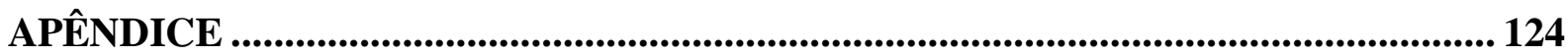


APÊNDICE A - Lista com as fontes manuscritas encontradas no Arquivo Público e Histórico de Ribeirão Preto "Casa da Memória", no fundo "Processos Antigos", $1^{\text {0 }}$ Ofício Cível, 1872-1917:

ANEXO A - Capa do primeiro processo judicial referente à tutela produzido em Ribeirão Preto (SP)

ANEXO B - Folha 1 do primeiro processo judicial referente à tutela produzido em Ribeirão Preto (SP) 138

ANEXO C - Folha 2 do primeiro processo judicial referente à tutela produzido em Ribeirão Preto (SP) 139

ANEXO D - Solicitação enviada ao Fórum de Ribeirão Preto para autorização de consulta ao acervo de processos judiciais sob custódia do Arquivo Público e Histórico de Ribeirão Preto para fins de trabalho acadêmico ANEXO E - Autorização para consulta ao acervo do Fórum de Ribeirão Preto disposto no Arquivo Público e Histórico de Ribeirão Preto para fins de trabalho acadêmico (Oficio $\mathrm{n}^{\circ}$. 033/2014 - jcg) 


\section{INTRODUÇÃO}

O trabalho ora apresentado tem como objetivo principal compreender a possível intervenção sobre a infância a partir da arbitragem das demandas envolvendo herdeiros, no caso da tutela, e desvalidos e pobres, quando da soldada em Ribeirão Preto entre os anos de 1872 e 1917. Como objetivo específico, pretende-se esclarecer como era realizado o tratamento e qualificação da infância ribeirão-pretana pelas fontes principais de pesquisa que fundamentaram as análises do trabalho: processos judiciais comumente nomeados como autos de tutela e contratos de soldada. Um "auto" corresponde às peças produzidas ao decorrer de um processo judicial, tal como petições, termos de audiência, certidões, entre outras. Também pode ser entendido como um termo ou instrumento circunstanciado de uma determinada diligência judicial e/ou administrativa, escrita e autenticada pelo escrivão ou tabelião. Esse termo passa a representar prova de uma determinada ocorrência. Ainda, pode equivaler-se em um ato público ou solene a fim de que se cumpra uma ordem legal ou de autoridade competente. Assim, no caso específico da tutela, equivale-se a dar encargo legal ou judicial a alguém que deverá administrar a conduta e/ou os bens do tutelado. Já a soldada fora uma espécie de contrato de trabalho firmado com uma criança, na qual, em troca de residente, alimentação, cuidados e educação e mediante a um pagamento, esta prestaria serviços à família que a contratara (AZEVEDO, 1995; BASTOS, 2012; SILVA, 2008; ZERO, 2004).

Ainda, especificamente, pretende-se esclarecer as possíveis justificativas para o encaminhamento de crianças que foram tuteladas e/ou contratadas, como também esclarecer os possíveis fundamentos jurídicos utilizados no decorrer da produção dos processos, buscando compreender se estes foram determinantes ou não para esse encaminhamento. O recorte selecionado para o desenvolvimento do trabalho justifica-se pelo fato de que o processo judicial referente à tutela e/ou soldada mais antigo encontrado no Arquivo Público e Histórico de Ribeirão Preto (APHRP) fora produzido no ano de 1872 (ANEXO A, B e C), e o ano de 1917 como sendo o ano inicial da vigência de um novo código regulador das questões privadas no país, o primeiro Código Civil brasileiro (Lei nº. 3.701).

$\mathrm{O}$ projeto de pesquisa que antecedeu o desenvolvimento do trabalho fora pensado a partir dos resultados de uma pesquisa também supervisionada pelo mesmo orientador desta em conjunto a outra orientanda (CASTRO, 2010) do curso de graduação em Pedagogia da Faculdade de Filosofia, Ciências e Letras de Ribeirão Preto (FFCLRP) da Universidade de São Paulo (USP), a qual tratou de processos crimes que envolviam menores e que os comparava com notas publicadas em periódicos em Ribeirão Preto (SP) no início do século XX, visto que 
em algumas dessas mesmas notas jornalísticas que envolviam crianças pobres era indicado o encaminhamento destas para a tutela. Assim, juntando-se o resultado obtido pela pesquisa citada anteriormente com meu interesse particular em estudar sobre a infância desvalida tendo a História da Educação como área de pesquisa, o cotidiano da infância desvalida em Ribeirão Preto (SP), entre os anos 1872 e 1917, a partir das intervenções do discurso jurídico do período pesquisado tornou-se objeto de estudo.

Previamente ao início formal do trabalho através do Programa de Pós-Graduação em Educação da FFCLRP-USP, realizei um levantamento preliminar das fontes de pesquisa, as quais se encontram no APHRP. Antes, tais processos judiciais encontravam-se sob custódia do Fórum da cidade, sendo encaminhados para o APHRP posteriormente. Nesse levantamento preliminar, foram selecionadas amostras, sendo lidas e analisadas de modo que auxiliassem na elaboração da proposta de pesquisa encaminhada para o processo seletivo do curso de mestrado em questão. Ainda em fase preliminar, a leitura flutuante da amostra permitiu notar que os processos de tutela e soldada, em geral, tratavam de questões concernentes à transmissão e gestão de bens herdados, ou em outros casos, resultavam do arbítrio judicial de contratos nos quais estava em questão o uso do serviço de crianças consentido pela lei. Ademais, esse processo de leitura resultou profícuo por revelar uma possível presença de discussões jurídicas sobre temas como família e infância no conteúdo desses documentos, por exemplo, além do fato de, por vezes, indicar ou não as razões que motivaram as pessoas a recorrerem ao judiciário para o arbítrio da tutela. Com isso, as perguntas que nortearam o desenvolvimento da pesquisa foram: as práticas de tutela e contratação de serviços de crianças eram voltadas apenas para assistir estas de acordo com o que previa a lei ou haviam outros interesses? E se haviam, quais seriam e como se fundamentavam juridicamente? Ainda, como tais influenciaram o cotidiano dessas mesmas crianças fora do âmbito jurídico?

As instâncias jurídicas que tratavam da infância no Brasil tinham como referência doutrinária as Ordenações Filipinas, sendo estas um conjunto de leis que regulavam jurídica e administrativamente o cotidiano das colônias e reinos de Portugal. Assim, eram nas Ordenações Filipinas que se encontravam os procedimentos a serem realizados em casos de solicitação de tutela e/ou contrato de soldada de crianças e também na obra de referência intitulada Primeiras linhas sobre o processo orphanologico, elaborada pelo jurista José Pereira de Carvalho (1888). Outras obras são citadas em alguns dos processos analisados, como Direito de Família, elaborada pelo também jurista Clóvis Beviláqua (1896), na qual versava, principalmente, acerca dos direitos reservados ao pater famílias em relação a organização familiar pela qual era juridicamente responsável. 
O processo judicial mais antigo localizado no APHRP fora produzido em $1^{\circ}$ de março de 1872. Nele, Theophilo Antunes Maciel solicita sua nomeação como tutor da criança de nome Manoel Sabino de Araujo, com idade entre 13 a 14 anos, filho da viúva Anna Maria Luisa e sem quaisquer bens materiais. Pressupõe-se também que este, possivelmente, visava seu reconhecimento judicial como figura paterna do menino, sendo este mencionado no documento ora como menor, ora como órfão. Como justificativa para sua nomeação, além de reconhecer ser o pai do menino, Theophilo informa que a criança se encontrava em seu poder há mais de seis anos e que proporcionava a educação necessária ao menino:

[Mmo. Sr.] Juiz de Orfãos

Dis Theophilo Antunes Maciel, morador neste distrito do Ribeirão Preto do municipio e termo de S. Simão, que o Supplicante tem em seu poder a mais de seis anos, um orfão de nome Manoel Sabino de Araujo, de idade de 13 a 14 annos, filho da viuva Anna Maria Luisa, cujo orfão o Supplicante reconhesse ser seo [filho] e como tal o tem em sua companhia dando lhe a educação precisa, assim como acha-se ele actualmente aprendendo as $1^{a}$ letras, [para] isso que o Supplicante requer a V.S. que nomeie do Supplicante [para] tutor do mensionado orfão, [o qual] não possue bens algum, e de tudo passando-se o respectivo termo, [para] [ilegível] o Supplicante.

P. a V.S. deferimento na forma requerida.

E. R. Mel.

[ilegível] de Tyophilo Antunes Maciel

Antonio [ilegível] Velloso [ilegível] ${ }^{1}$

Ainda, Theophilo aceita formalmente o compromisso do cargo de tutor e suas obrigações, conforme consta no termo de tutela produzido e anexado ao processo:

Tutêlla

Ao primeiro dia do mez de Março de mil oitocentos e setenta e dois nesta Villa do Ribeirão Preto onde se achava o meretissimo Juiz Municipal e Orfãos segundo suplente em exercicio o Cidadão Zeferino de Souza Nogueira commingo escrivão de seu cargo abaixo assignado, e ahi presente Theophilo Antunes Maciel, lhe foi deferido pelo juiz a juramento aos Santos Evangelhos debaixo do qual lhes encarregou que na qualidade de tutor do orfão Manoel Sabino de Araujo cuidasse escrupulozamente da sua educação, defendendo sua pessoa, tanto em juizo, como fora dele ezilhado de sua pessõa sendo per ele asseito a juramento assim prometteu cumprir do que para constar mandou lavrar este termo que pelo tutor não saber escrever assigna [ilégível] o Capitão Luiz Antonio de Oliveira com Juiz Eu José Paulino de Gaurca escrivão de Orfãos [escrevi].

[ilegível]

Luiz Antonio de Oliveira ${ }^{2}$

Foi verificado durante as análises dos processos selecionados - já durante o desenvolvimento da pesquisa junto ao Programa de Pós-Graduação em Educação - que a legislação voltada aos órfãos, geralmente, era citada no corpo do texto dos processos para que amparasse as justificativas de encaminhamento da criança para ser tutelada e/ou contratada.

\footnotetext{
${ }^{1}$ APHRP, 1872, Fundo "Processos Antigos", Caixa 41-A, Processo 1.

${ }^{2}$ Ibidem.
} 
Contudo, em alguns processos não foi possível verificar esse embasamento jurídico pelo solicitante ao realizar seu pedido em tutelar ou contratar uma criança. Nesses casos, o solicitante informava que a criança se encontrava em sua companhia, em muitas das vezes há anos, ou então denunciava que uma determinada criança se encontrava em situação de orfandade, abandono e/ou pobreza, sendo que muitos desses pedidos sem fundamentação jurídica no corpo do processo foram deferidos pelo Juiz de Direito da cidade.

Assim, considerando os achados da pesquisa, é possível sugerir que os mecanismos de regularização, controle e vigilância da infância, principalmente a desvalida, relacionavam-se não apenas ao instituto jurídico ${ }^{3}$, mas também aos valores e práticas operantes no cotidiano da sociedade local. Assim, o ato de governar a infância - tomando para esse trabalho a palavra governar em seu sentido original, referindo-se ao ato de regular o andamento de algo, ter poder ou autoridade sobre algo ou alguém, ter grande influência sobre algo ou alguém ou realizar algum tipo de encaminhamento a fim de solucionar alguma situação (FERREIRA, 2004) - e o cotidiano da cidade tornou-se uma saída viável juridicamente para lidar com os problemas de orfandade, principalmente quando associados à marginalidade.

\footnotetext{
${ }^{3}$ No presente trabalho, entende-se por instituto jurídico a definição apresentada por Paulo Nader (2008, p. 84, grifo nosso): "Instituto Jurídico é a reunião de normas jurídicas afins, que rege um tipo de relação social ou interesse e que se identifica pelo fim que procura realizar. É uma parte da ordem jurídica e, como esta, deve apresentar algumas qualidades: harmonia, coerência lógica, unidade de fim. Enquanto a ordem jurídica dispõe sobre a generalidade das relações sociais, o instituto se fixa apenas em um tipo de relação ou de interesse: adoção, pátrio poder, naturalização, hipoteca etc.”.
} 


\section{A PESQUISA COM PROCESSOS JUDICIAIS: O CASO DE RIBEIRÃO PRETO} (1872-1917)

\subsection{Processos judiciais como fonte de pesquisa: alguns apontamentos}

Sobre a utilização de processos judiciais como fonte de pesquisa, Keila Grinberg (2013) explica que tal deve ser realizada com cautela, uma vez que "o objetivo primeiro da produção do documento não é reconstituir um acontecimento - o que, de resto, jamais poderia ser - mas buscar ou produzir uma verdade, acusando e punindo alguém" (GRINBERG, 2013, p. 127). É necessário ter o entendimento sobre a finalidade da produção do processo, ou seja, o pesquisador deve tomá-lo como fonte sabendo que não irá encontrar nele, necessariamente, a verdade ou não sobre o fato que está sendo acompanhado pela justiça, mas sim versões sobre esse tal fato, pois é impossível descobrir o que verdadeiramente se passou. Assim, a opção por se elucidar o ocorrido pelos processos selecionados se justifica pelo fato de que o pesquisador, o qual utiliza processos antigos como fonte, deve ter como chave para desencadear suas análises o processo de transformação da situação ocorrida em um processo judicial, tomando o contexto da construção do discurso jurídico que ali será encontrado. Conforme explica Grinberg (2013, p. 128, grifo nosso):

É justamente na relação entre a produção de vários discursos sobre o crime e o real que está a chave da nossa análise. O que nos interessa é o processo de transformação dos atos em autos, sabendo que ele é sempre a construção de um conjunto de versões sobre um determinado acontecimento.

Tão importante quanto investigar acerca do fato ocorrido, os sujeitos envolvidos e extrair todas as informações possíveis e disponíveis, é ter a percepção e ser receptivo aos detalhes que poderão estar ausentes, nebulosos e nas entrelinhas. Também, buscar preencher as lacunas com outras fontes, realizando possíveis inferências, uma vez que "[...] é fundamental que os processos sejam tomados também como 'mecanismos de controle social', marcados necessariamente pela linguagem jurídica e pela intermediação do escrivão" (GRINBERG, 2013, p. 126). Além disso, os processos contêm dados que possibilitam compreender o cotidiano das pessoas neles envolvidas, uma vez que indicam endereços, possíveis hábitos e valores, os quais podem levar a formulação de possíveis contextos aplicados a ação descrita.

Contudo, é necessário atentar-se à natureza dos processos no que se refere ao seu viés de seleção. Conforme explica Karl Monsma (2011), a seleção realizada de modo não aleatório sobre os fenômenos ali descritos pode enviesar o entendimento da ocorrência das ações que se 
encaixam no objeto pesquisado através dos processos, levando a possíveis conclusões errôneas sobre o contexto de produção destes. Monsma (2011, p. 34) indica que seja feito um:

[...] procedimento qualitativo, mais viável para a pesquisa histórica, que permite examinar os processos de seleção e pensar sobre suas prováveis consequências. Isso é coletar informações sobre as etapas anteriores mais importantes, comparar resultados das distintas etapas e fazer uma análise do resultado final para todas as unidades, inclusive aqueles que foram eliminados já na primeira etapa. Este procedimento não resolve todos os problemas de seletividade, mas pelo menos permite avaliar melhor as consequências desta para a análise.

Visto isso, torna-se relevante compreender a natureza do problema pesquisado para esforçar-se em contornar o possível viés de seleção, como também o estudo de trabalhos anteriores que se assemelhem com a temática proposta e o estudo preliminar das fontes para compreender como tais estão organizadas e se será possível encontrar nelas o que, de fato, se busca atingir pela pesquisa. Tal estudo, principalmente o preliminar das fontes, poderá contribuir para novas e melhores percepções das condições de produção dos processos e, consequentemente, das motivações de abertura e o contexto em que tal ocorreu (MONSMA, 2011).

André Rosemberg e Luís Antônio Francisco de Souza (2009), ao comentarem sobre o uso de documentos judiciais e policiais como fontes históricas para pesquisa, sugerem que o estudo de tais fontes se encaixe em um conjunto de questões produtivas para o entendimento da existência de conhecimentos históricos que extrapolam o discurso produzido pelos/nos próprios documentos. Os autores explicam, porém, que tanto a documentação judicial pode ser um meio de recontar aspectos regulares da época pesquisada, principalmente as dos sujeitos que se tornaram alvos da justiça e, consequentemente, do seu poder, mas como também que o discurso jurídico pode não dar a possibilidade do pesquisador transcender as fronteiras deste, levando apenas a uma pequena análise metalinguística ou uma pequena ideia dos fundamentos ideológicos ali presentes. Neste último caso, o uso dos documentos judiciais apenas pode "fornecer dados para a história da justiça, como fonte para a análise do discurso produzido pelos operadores do Direito, ou [...] comparação de representações presentes no meio social mais amplo e decalcadas no ambiente jurídico" (ROSEMBERG; SOUZA, 2009, p. 160). Contudo,

os historiadores que lançam mão da documentação [...] concordam que a partir do discurso construído pelas instâncias jurídicas, mesmo de maneira escusa e deturpada, seria possível desemaranhar do novelo da linguagem técnica e do discurso constritor, que é próprio da Justiça, tensões, atitudes, visões de mundo, experiências - enfim um conjunto de atributos culturais - dos atores sociais enredados no processo judicial e que culminaram na inauguração daquele ato formal. (ROSEMBERG; SOUZA, 2009, p. 162). 
Assim, um dos grandes desafios que os pesquisadores que utilizam processos judiciais como fontes históricas para fins de estudo é o de não tomar a “"verdade formal', dos autos, com 'a verdade material', presente "no mundo objetivo"' (ROSEMBERG; SOUZA, 2009, p. 165), mas sim compreender as possíveis "nuanças intrínsecas aos processos judiciais, como fruto de uma construção historicamente contextualizada e ancorada em interesses difusos" (ROSEMBERG; SOUZA, 2009, p. 165). Os processos, portanto, devem ser entendidos como um instrumento para a construção de uma verdade, sendo esta elaborada com a finalidade de impor determinado código regulador produzido pelos atores que ocupavam a posição de poder a qual lhes permitia tal estratégia de controle, vigilância e punição da sociedade civil, uma vez que:

[...] é fato que nessa disputa as forças tendem a ser desiguais, pois a capacidade de combate de cada um dos querelantes não é neutra, nem equitativa. Aquilo que é produzido como evidência nos autos do processo vem carregado de uma carga ideológica, cujas origens estão fora do processo e se encontram no 'mundo real', mundo que, segundo o famoso brocardo ('o que não está nos autos, não está no mundo'), não deveria influir na capacidade de convencimento do julgador. (ROSEMBERG; SOUZA, 2009, p. 167).

O discurso jurídico, seja proferido ou escrito, é concebido a partir de uma carga ideológica que procura culminar na manipulação da verdade, em sua maioria enviesando-se a favor dos que o produzem. Para que então o conteúdo documentado pelo processo seja examinado sem o perigo de interpretações que extrapolem suas possibilidades de releitura, o processo - a peça judicial - deve ser tomado com um "processo", como o desenvolvimento da situação retratada, observando-se tanto a frequência das discussões quanto as possíveis ausências de descrições que poderiam mudar o rumo da decisão tomada ao final deste (ROSEMBERG; SOUZA, 2009).

Especificamente sobre a questão do poder e interpretação de processos judiciais para fins de pesquisa, Fabiana Luci de Oliveira e Virgínia Ferreira da Silva (2005) entendem que diferentes pesquisas, ao fazerem uso de tais fontes, trabalham "com a interpretação da palavra escrita a fim de discorrer sobre a construção do discurso empreendido por determinados grupos sociais" (OLIVEIRA; SILVA, 2005, p. 244). O desenvolvimento de uma pesquisa documental tomando processos históricos e oficiais como fontes supõe duas possíveis implicações metodológicas, sendo referentes ao poder e interpretação dos documentos. A questão do poder implica-se ao fato de que tais fontes teriam como seu verdadeiro produtor o Estado e, assim, teriam a expressão de grupos sociais ali presentes por depoimentos, por exemplo, encobertos, como também as argumentações de agentes oficiais. Já a questão da interpretação implica-se ao fato de que ao trabalhar com tais documentos, trabalha-se com o que está escrito e com o 
que não está escrito, ou seja, com o cenário trazido pelo processo, como também “porque não estamos interpretando por meio da observação direta, mas por meio da palavra escrita, e isto é fonte de inúmeros questionamentos, que envolvem a questão da subjetividade" (OLIVEIRA; SILVA, 2005, p. 245). Contudo, as autoras alertam para o fato de que:

[...] o processo não deve ser visto apenas como expressão do Estado, e este não deve ser visto como emissor dos depoimentos. É necessário considerar os filtros que a justiça impõe, mas não se deve considerar que a narrativa não contenha o modo como determinada pessoa vivencia sua realidade. O processo contém formulações dos diversos segmentos envolvidos e não apenas a do Estado. (OLIVEIRA; SILVA, 2005, p. 252).

Deve-se atentar ao fato de que o pesquisador que utiliza tais fontes, ao interpretar o que está escrito nos documentos, pode construir sua visão a partir do que foi construído pelo narrador encontrado na escrita. Assim, torna-se essencial para o desenvolvimento do trabalho compreender que os possíveis resultados obtidos pela leitura e análise dos processos, em detrimento das interpretações, sejam realizados dentro de um específico contexto histórico, o que demonstra a importância acerca do estudo de pesquisas anteriores que utilizaram fontes semelhantes, como também o estudo acerca do recorte temporal selecionado no que se refere ao objeto de pesquisa. A análise das narrativas encontradas nos processos é um meio de buscar como a ocorrência de certos comportamentos foram transmitidos e como tais foram construídos a partir do discurso encontrado nas fontes, levando a uma compreensão da lógica de produção e disseminação do discurso sobre os comportamentos realizados pelo grupo social que se encontra nos documentos (OLIVEIRA; SILVA, 2005).

Michel Foucault (2013) busca demonstrar como questões econômicas, políticas e existenciais não compõem uma barreia para o sujeito do conhecimento, contrapondo-se ao discurso do marxismo acadêmico dos anos de 1960 e 1970 na França. Para Foucault, tais condições são terreno fértil para que os sujeitos se desenvolvam, assim como o domínio do saber e sua relação com a verdade. As práticas jurídicas seriam, então, práticas sociais as quais pavimentam o surgimento de outras e novas formas da verdade e da subjetividade (FOUCAULT, 2013). O autor explica que:

as práticas judiciárias - a maneira pela qual, entre os homens, se arbitram os danos e as responsabilidades, o modo pelo qual, na história do Ocidente, se concebeu e se definiu a maneira como homens podiam ser julgados em função dos erros que haviam cometido, a maneira como se impôs a determinados indivíduos a reparação de algumas de suas ações e a punição de outras, todas essas regras ou, se quiserem, todas essas práticas regulares, é claro, mas também modificadas sem cessar através da história $-[\ldots]$ parecem uma das formas pelas quais nossa sociedade definiu tipos de subjetividade, formas de saber e, por conseguinte, relações entre o homem e a verdade que merecem ser estudadas. (FOUCAULT, 2013, p. 21). 
Para Foucault (2013) torna-se necessário a aproximação às formas de poder para o entendimento de novos conhecimentos, levando-se em conta o conhecimento no modo de acontecimento, as consequências de ação e subterfúgios e do resultado das relações de poder envoltos.

Observa-se que os autores citados anteriormente explicam sobre a necessidade do pesquisador que tomará processos judiciais de séculos anteriores como fonte de pesquisa em atentar-se a questões sobre o conteúdo dos documentos, principalmente no que se refere sobre a interpretação das ações ocorridas e descritas, considerando a instituição jurídica e seus modos de produção acerca do poder diante da sociedade civil. Assim, torna-se profícuo compreender que o desenvolvimento das análises dos processos deve levar em consideração não apenas o que está descrito ou não nestes, mas também o entendimento do contexto histórico, político, econômico e social do período em que foram produzidos.

\subsection{Sobre a urbe interiorana de Ribeirão Preto: breve histórico e dados demográficos}

Ribeirão Preto encontra-se situada no interior de Estado de São Paulo, sendo um dos municípios mais importantes da região devido as grandes transformações ocorridas e que levaram a cidade a alcançar notoriedade nacional através da cultura do café. Fundada em 1856, a partir da doação de terras de fazendeiros, fora demarcada e teve sua primeira capela construída. A criação do município ocorreu através da Lei Provincial $n^{o} 51$, de 2 de abril de 1870 (RIBEIRÃO PRETO, 1870), elevando-se à Freguesia (Distrito de Paz) de São Sebastião de Ribeirão Preto, em um terreno onde hoje se encontram as cidades de Sertãozinho, Cravinhos, Serrana, Pontal, Dumont, Guatapará e o Distrito de Bonfim Paulista. Em 12 de abril de 1871, através da Lei Provincial $n^{o} 67$ (RIBEIRÃO PRETO, 1871), eleva-se então para a categoria de Vila, desmembrando-se do município de São Simão. Apesar disto, o município de Ribeirão Preto só fora realmente instalado em 1874 pela posse de seus primeiros vereadores, após a realização da primeira sessão da Câmara Municipal e pela Lei $n^{\circ} 88$, em $1^{\circ}$ de abril de 1889 (RIBEIRÃO PRETO, 1889), recebeu o predicado de cidade. Com sua elevação à Freguesia, Ribeirão Preto passou a pertencer a Comarca de Mogi Mirim (1870), posteriormente à Casa Branca (1872), Batatais (1875) e São Simão (1877). Porém, é somente em 25 de agosto de 1892, 
pela Lei $n^{o} 80$ (RIBEIRÃO PRETO, 1892), que Ribeirão Preto é elevada à categoria de Comarca, abrangendo os municípios de Cravinhos, Serrana, Serra Azul, Pontal e Dumont. ${ }^{4}$

A cultura cafeeira na região provocou grandes avanços na economia local, uma vez que o plantio do café vingou em terras ribeirão-pretanas por conta da adaptação ao solo fértil, a terra-roxa, além do clima ideal. Complementando esse crescimento econômico, a região recebeu imigrantes europeus que trabalhavam nas fazendas de café. Acerca dos imigrantes italianos, estes foram maioria se comparados com outros sujeitos de nacionalidades diferentes na região, estabelecendo-se com suas famílias nucleares (cônjuges e filhos) ou não nucleares (composta por membros de uma mesma família, mas com diferentes graus de parentesco) e contribuindo para o aumento populacional na cidade (CALSANI, 2014).

Toda essa fase de expansão da cafeicultura em Ribeirão Preto ocorreu na década de 1870, se estabelecendo na década de 1880, consolidando-se em 1890 e entrando em declínio entre 1900 e 1920 (DE TILIO, 2005). Conforme os dados obtidos por Rafael De Tilio (2005), em consulta ao portal de estatísticas do Estado de São Paulo, a Fundação Sistema Estadual de Análise de Dados (SEADE), os dados acerca do crescimento populacional em Ribeirão Preto são de surpreender. No ano de 1869 a região contava com quase 3.000 habitantes e quando municipalizada, em 1874, Ribeirão Preto contava 5.552 habitantes. Em 1886, o número subiu para 10.420 e em 1900, no período de acentuação do número de imigrantes na região, a cidade contava com 59.195 pessoas, sendo que em 1920 estimava-se que a população ribeirão-pretana chegava em 68.838. O crescimento e desenvolvimento urbano em Ribeirão Preto, além de gerar um enriquecimento e fortalecimento do poderio político na região, também gerou problemas na estrutura de atendimento a moradia, saúde e educação na cidade e, consequentemente, originou as camadas menos abastadas e, com isso, a infância desvalida na cidade (FONSECA; CASTRO, 2013).

Importantíssimo de ser contextualizada por conta do recorte temporal do trabalho ora apresentado (1872-1917), observa-se o movimento da Belle Époque no Brasil, principalmente nas regiões cafeeiras. Vertente do movimento europeu originado na França, ao ser instalado em terras brasileiras deu início a mudanças no cenário político, cultural e artístico do país entre o final do período imperial até o final da República Velha (1889-1931). No caso de Ribeirão Preto, encontrando-se no Estado de São Paulo, a região tornou-se uma das mais desenvolvidas economicamente devido a cafeicultura, contribuindo para o crescimento industrial da região.

\footnotetext{
${ }^{4}$ Dados obtidos no website do ARQUIVO PÚBLICO E HISTÓRICO DE RIBEIRÃO PRETO. Disponível em: $<$ http://www.ribeiraopreto.sp.gov.br/scultura/arqpublico/i14index.php?pagina=/scultura/arqpublico/historia/i14in dice.htm>. Acesso em: 2 jul. 2015.
} 
Contudo, entende-se que a relação com tal movimento na região, além da grande influência econômica, teve como outro protagonista o desenvolvimento cultural na cidade, pois "muitos homens no interior paulista tinham seus sonhos povoados por desejos como o de viver um grande amor em Paris, desfrutar de seus cafés e cabarets [...]” (DOIN et al., 2007, p. 94). Além de se propor a civilizar a população ribeirão-pretana, os grandes homens da elite da cidade procuravam aliar-se ao sentimento de modernidade que tomava a Europa na época, com a transformação social da população e a transformação material da própria cidade. Contudo, é necessário atentar-se a questão do moderno proposto por estes, uma vez que tais visavam apenas conceder ainda mais privilégios para as camadas que já detinham grande poder econômico, político e social na cidade:

A Belle Époque caipira era constituída especialmente pela ação de uma elite desejosa
de modernizar-se. Desobrigados de qualquer ética, derribavam as matas, levando
destruição, morte e grilagem às terras férteis do sertão. Tal qual verdadeiros
flibusteiros, adentravam a hinterlândia e agiam com violência, amparados na
legitimidade de um discurso constituído a partir da significação social positiva
atribuída ao moderno. Assim, o café seguia impávido, ladrilhando as localidades
outrora semeadas e levando os trilhos e silvos das locomotivas em seu rastro. Rápido,
então, lugarejos cresciam e tomavam forma de cidades, tornando-se, assim, centros
bafejados pela força da grana que construía e destruía coisas belas, um verdadeiro
admirável mundo, que mesclava sem possibilidades de separação o arcaico e o novo.
Era nesse contexto que as ambivalências da própria modernidade se somavam às
contradições de um país e de um povo forjado sob o sopro da bricolagem e da
imposição do poder público. (DOIN et al., 2007, p. 95).

Conforme explica Rodrigo Ribeiro Paziani (2014), Ribeirão Preto, até meados da década de 1870, nada mais era do que um singelo vilarejo, mas devido a instalação das estradas de ferro auxiliando ainda mais o movimento de migrações e imigrações para a região e o adendo da produção e exportação do café ganhando destaque e gerando riquezas, a Vila entrou em um processo de transformação para uma cidade com ares de modernidade. Assim, o projeto de modernização proposto buscava, antes de qualquer coisa, a ocultação e até mesmo a limpeza e extermínio de espaços considerados "mal frequentados" (PAZIANI, 2014). Ainda sobre a questão das transformações trazidas pela busca da modernidade, o autor sintetiza que:

O turbilhão de mutações e experiências sofridas por várias capitais europeias nos séculos XVIII e XIX correspondia aos efeitos e impasses da modernidade: de um lado, a industrialização, a urbanização e a ampliação das capacidades técnico-científicas; de outro, o crescimento demográfico, as crises urbanas e as desigualdades sociais. As contradições vividas pelas sociedades levavam suas elites a impor, cada vez mais, um processo amplo de reformas urbanas projetadas por homens dotados de um discurso "racional" e "técnico". Embora marcados por uma proposta global e sistêmica, tais processos situavam-se nos quadros de uma intervenção parcial e de acordo com suas condições de possibilidades. (PAZIANI, 2004, p. 169). 
É neste período também que Ribeirão Preto é denominada como Petit Paris por conta da transformação da cidade, a qual aspirava atingir o possível patamar de metrópole, considerando o desenvolvimento da região graças à ocupação ferroviária e que pavimentou a atração da sociedade ribeirão-pretana aos moldes europeus no que se refere ao consumo de cultura (PAZIANI, 2004).

A mulher ribeirão-pretana tornou-se um alvo, por vezes direto ou indireto, devido as mudanças que ocorriam na cidade em busca à modernidade europeia, uma vez que "[...] coube à mulher o papel de modelo das normas pré-estabelecidas, a fim de transmitir os princípios considerados corretos" (PERINELLI NETO; FRANÇA, 2009, p. 2), mas ainda ocupando um papel ambíguo de acordo com o que propunha a população masculina, branca e elitizada, sendo que a mulher "[...] passa a ser vislumbrada, mais do que nunca, como símbolo do processo civilizador/educador: tanto a esposa associada ao espaço privado quanto a meretriz ligada ao universo público" (PERINELLI NETO; FRANÇA, 2009, p. 2). O interesse pela sexualidade feminina toma forma pela vinda das influências da moda europeia através das meretrizes dos cabarés instalados na cidade e que passaram a despertar o interesse das damas da elite ribeirãopretana, mas também "o pudor gerado por um sentimento de decência, vergonha e honestidade relacionava-se com atos de recato do sexo" (PERINELLI NETO; FRANÇA, 2009, p. 2).

Com a busca pelo cumprimento de normas sociais estimuladas pela elite, o poder local criou dispositivos legais a fim de coibir comportamentos considerados inadequados, tendo o amparo do Código Penal de 1890 para ratificar as punições de ações consideradas como atentados à honra feminina. Contudo, "ele foi (de quando em quando) utilizado para benefícios pessoais, tais como: a contratação de casamento, a sentença favorável a possíveis corruptores de menores, defloradores, estupradores, raptores, que atentavam contra a moral e/ou praticavam atos libidinosos" (PERINELLI NETO; FRANÇA, 2009, p. 3).

Assim, junto com a modernidade que se instalava em Ribeirão Preto, observava-se as mais diversas manifestações artísticas e culturais por parte da elite, sendo que o interesse de cunho sexual se mostrava de modo paradoxal: se por um lado priorizava-se o recato feminino pelas moças de famílias mais abastadas, por outro lado os moços dessas mesmas famílias gozavam do direito de usufruir da sexualidade feminina através da instalação de casas de "entretenimento" que nada mais eram do que prostíbulos de luxo, a exemplo do bordel "Eldorado", como também outro locais como o Teatro Carlos Gomes e o Cassino Antártica, também administrados pelo mesmo dono, o francês François Cassoulet (PERINELLI NETO; FRANÇA, 2009). Pode-se observar as diferenças de gênero inclusive pelas vias judiciais em 
Ribeirão Preto desde o início de sua instituição - as quais serão exploradas mais à frente no trabalho ora apresentado.

Por fim, entende-se que o caso de Ribeirão Preto apresenta paradigmas e paradoxos de uma cidade em busca da modernidade, mas ainda se fundamentando em ideais conservadores dignos de uma localidade interiorana. Entendendo a urbe ribeirão-pretana como local de produção de contradições socioeconômicas, conclui-se com Paziani (2005, p. 200) que:

[...] a população ribeirão-pretana associava normas e transgressões, ordem e desordem, progresso e progressos: se, por um lado, passava custar caro às camadas sociais da cidade participar do processo de modernização e dele beneficiar-se, por outro, a intensificação dos dramas diários e a emersão de cenas emblemáticas e cruéis alertavam as autoridades municipais para os perigos e as aventuras de se viver em centros urbanos.

\subsubsection{Ribeirão Preto do passado em números}

Os dados demográficos obtidos através do primeiro Recenseamento da População do Império do Brasil de 1872, encomendados pelo Imperador Dom Pedro II - e que, coincidentemente, fora realizado no mesmo ano em que nossa pesquisa inicia seu recorte cronológico -, e organizados pelo Núcleo de Estudos de População da Universidade Estadual de Campinas (UNICAMP), auxilia na compreensão acerca da quantidade de população livre e escrava, adulta e infanto-juvenil em Ribeirão Preto no referido período. Esses dados obtidos em consulta as obras organizadas por Maria Silva C. Beozzo Bassanezi (1998; 1999) também tiveram como fontes o Ensaio d'um Quadro Estatístico de S. Paulo - 1836, organizado por Daniel Pedro Müller, engenheiro militar que viveu entre 1785 a 1841, o Quadro Estatístico da População da Província de São Paulo Recenseada no anno de 1854 e o Quadro Estatístico do Movimento da População da Província de S. Paulo durante o Anno de 1854, organizados por José Joaquim Machado de Oliveira, político e militar, além de ter sido presidente de algumas províncias brasileiras e que viveu entre 1790 a 1867, como também o Relatório apresentado ao Exmo. Sr. Presidente da Província de S. Paulo pela Commissão Central de Estatística, contendo informações acerca do ano de 1886 e os recenseamentos dos anos de 1890 e de 1920.

A tabela 1 tem como finalidade apresentar em números a população ribeirão-pretana do ano de 1872, dividindo-se em relação a condição social, sexo e grupos de idades. As legendas LM, EM, LF e EF dizem a respeito, respectivamente, a divisão entre população livre masculina, escrava masculina, livre feminina e escrava feminina e são referentes a divisão de sexo e condição social que, no caso, equivale-se a situação de ser livre ou escravo. Os grupos de idades estão divididos em meses (iniciando-se do $1^{\circ}$ mês de vida ao $11^{\circ}$ ), anos completos (iniciando- 
se do $1^{\circ}$ ano de vida ao $5^{\circ}$ ), quinquênios (agrupando as idades de 6 a 30 anos e dividindo-se de 5 em 5 anos), decênios (agrupando as idades de 31 a 100 e dividindo-se de 10 em 10 anos), os que teriam mais de 100 anos e aqueles cujos não tiveram suas idades identificadas (NI - não identificadas), levando à totalidade da população ribeirão-pretana do ano de 1872.

Tabela 1 - População total segundo grupos de idade, sexo e condição social em Ribeirão Preto (1872)

\begin{tabular}{|c|c|c|c|c|c|c|c|c|c|}
\hline \multicolumn{10}{|c|}{ Meses } \\
\hline População & 1 & 2 & 3 & 5 & 6 & 7 & 9 & 10 & $\overline{11}$ \\
\hline $\mathrm{EF}$ & 0 & 0 & 0 & 0 & 0 & 0 & 0 & 0 & 0 \\
\hline LF & 4 & 3 & 4 & 4 & 5 & 6 & 2 & 11 & 1 \\
\hline EM & 0 & 0 & 0 & 0 & 0 & 0 & 0 & 0 & 0 \\
\hline LM & 6 & 6 & 5 & 6 & 4 & 11 & 13 & 14 & 24 \\
\hline \multicolumn{10}{|c|}{ Anos completos } \\
\hline \multicolumn{2}{|c|}{ População } & 1 & \multicolumn{2}{|r|}{2} & \multicolumn{2}{|l|}{3} & 4 & \multicolumn{2}{|c|}{5} \\
\hline $\mathrm{EF}$ & & 0 & \multicolumn{2}{|r|}{0} & \multicolumn{2}{|l|}{8} & 14 & \multicolumn{2}{|c|}{23} \\
\hline LF & & 30 & \multicolumn{2}{|r|}{34} & \multicolumn{2}{|c|}{51} & 57 & \multicolumn{2}{|c|}{99} \\
\hline EM & & 0 & \multicolumn{2}{|r|}{0} & \multicolumn{2}{|l|}{8} & 18 & \multicolumn{2}{|c|}{30} \\
\hline LM & & 19 & \multicolumn{2}{|r|}{31} & \multicolumn{2}{|c|}{42} & 52 & \multicolumn{2}{|c|}{108} \\
\hline \multicolumn{10}{|c|}{ Quinquênios } \\
\hline \multicolumn{2}{|c|}{ População } & 6-10 & \multicolumn{2}{|r|}{ 11-15 } & \multicolumn{2}{|c|}{ 16-20 } & $21-25$ & \multicolumn{2}{|c|}{$26-30$} \\
\hline $\mathrm{EF}$ & & 76 & & 36 & 15 & & 23 & & \\
\hline LF & & 461 & & 378 & 23 & & 193 & & \\
\hline EM & & 161 & & 85 & 43 & & 43 & & \\
\hline $\mathrm{LM}$ & & 562 & & 295 & 25 & & 234 & & \\
\hline & & & & Decên & & & & & \\
\hline População & $31-40$ & $41-50$ & $51-60$ & 61-70 & $71-80$ & $81-90$ & 91-100 & +100 & NI \\
\hline $\mathrm{EF}$ & 46 & 25 & 1 & 3 & 2 & 4 & 0 & 0 & 0 \\
\hline LF & 250 & 107 & 110 & 28 & 5 & 0 & 0 & 0 & 0 \\
\hline EM & 69 & 23 & 15 & 13 & 12 & 0 & 0 & 0 & 21 \\
\hline LM & 426 & 62 & 4 & 6 & 8 & 1 & 0 & 0 & 1 \\
\hline Populaç & ho $\mathrm{EF}(\mathrm{e}$ & crava fer & minina): 2 & 291 & Popu & ação EM & I (escrava m & sculina) & \\
\hline Popula & ão LF (1 & vre femi & (nina): 2.2 & 255 & Pop & lação LN & 4 (livre mass & slina): 2 & \\
\hline & & $\mathrm{To}$ & otal - Pops & ulação esc & va e livr & 5.552 & & & \\
\hline
\end{tabular}

Fonte: BASSANEZI (1998)

Acompanhado os números expressados pela tabela 1 é possível observar que a população de crianças escravas (feminina e masculina) mostrou-se presente apenas a partir dos 3 anos completos, com a quantidade de 16 crianças. Já a população de crianças livres (feminina e masculina) mostrou-se presente desde o $1^{\circ}$ mês de idade, com a quantidade de 372 crianças com até 3 anos completos. Pressupõe-se que a inexistência de crianças escravas antes dos 3 anos de idade completos poderia ser explicada por falta de condições de cuidados básicos, como alimentação e higiene adequados que poderiam levar crianças tão pequenas com uma grande necessidade de cuidados ao óbito, como também a ocultação das mesmas pelos próprios pais a 
fim de preservá-las de sua futura exploração como escravas. Também, é possível observar um aumento na população escrava (feminina e masculina) no quinquênio de 6 a 10 anos de idade, com a quantidade de 237 crianças, sofrendo uma queda durante os quatro quinquênios seguintes, uma pequena elevação no decênio de 31 a 40 anos, com a quantidade de 115 adultos escravos e sofrendo uma queda nos decênios seguintes, resultando na quantidade de apenas 4 mulheres escravas no decênio de 81 a 90 anos.

O gráfico 1 tem como finalidade apresentar as porcentagens da população de Ribeirão Preto no ano de 1872, tendo como divisão a condição social (livre e escrava) e sexo (feminino e masculino).

Gráfico 1 - Porcentagem da população total de Ribeirão Preto segundo condição social e sexo (1872)

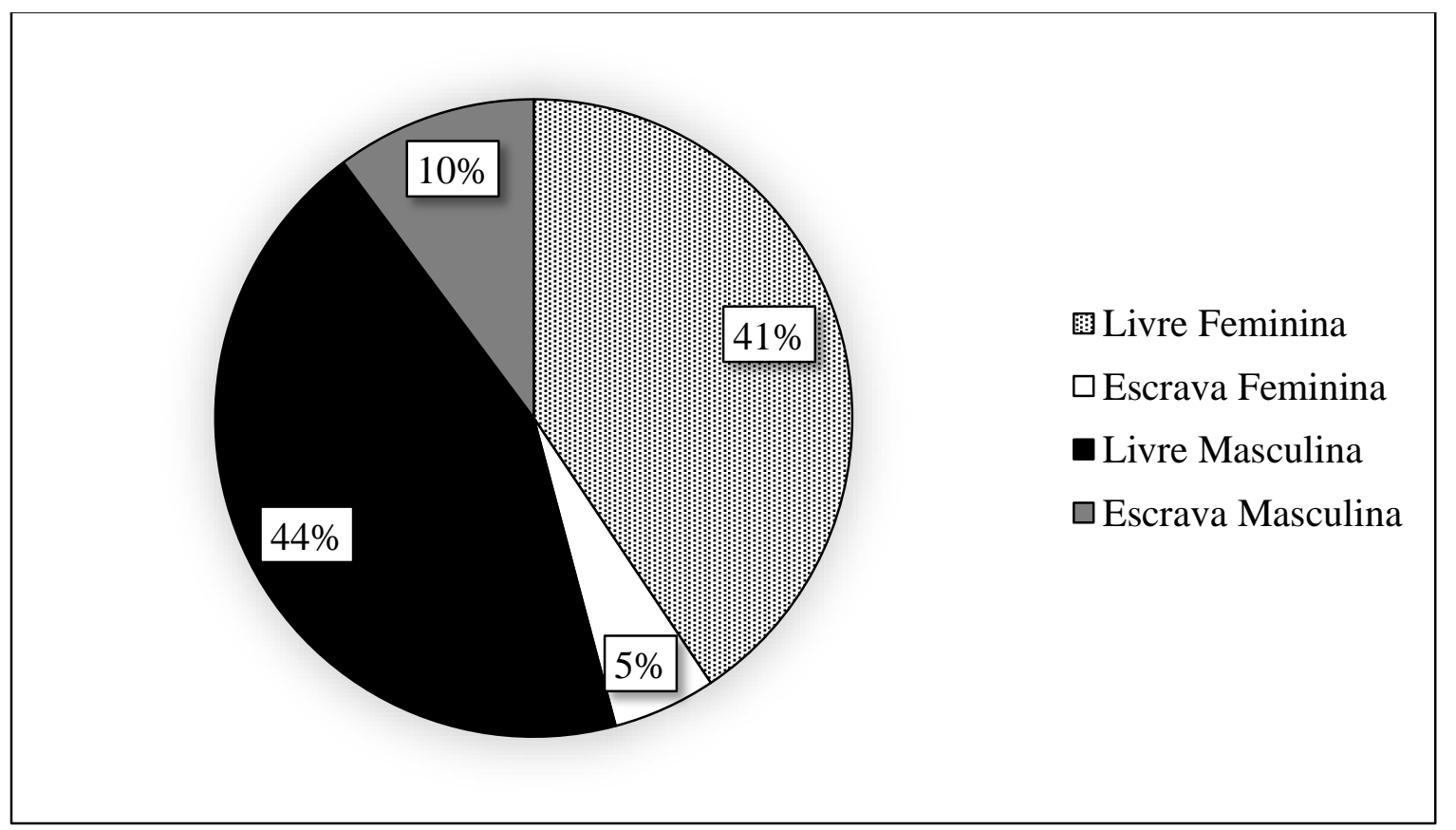

Fonte: BASSANEZI (1998)

De acordo com o gráfico 1, a população escrava (feminina e masculina) era de $15 \%$ em Ribeirão Preto no ano de 1872, sendo que a população livre (feminina e masculina) era de $85 \%$. Ainda, é possível observar que a diferença entre a população escrava masculina (10\%) era o dobro da escrava feminina (5\%), sendo que a diferença entre a população livre masculina (44\%) pouco se distanciava da livre feminina (41\%).

A Ribeirão Preto de 1872 acabara de ser elevada à condição de Vila, o que significava a autonomia dos moradores da região para eleger as autoridades locais, uma vez que esta contaria, a partir de então, com uma Câmara de Vereadores e demais autoridades (LAGES, 2012). Conforme citado anteriormente, em 1872, Ribeirão Preto se mostrava com grande 
potencial econômico devido a cultura cafeeira e tornou-se um local de extremo interesse para negociantes e políticos, uma vez que o apogeu do café se encontrava fortemente ligado com questão políticas da Província de São Paulo. Ainda em 1872, a Vila de São Sebastião do Ribeirão Preto contava com poucos habitantes, sendo a razão de adultos e crianças equilibrada.

A tabela 2 tem como finalidade demonstrar o aumento populacional em Ribeirão Preto de 1872 até 1886 , tendo dobrado o número de habitantes na cidade entre indivíduos livres e escravos. Ainda, é possível observar a taxa anual de crescimento populacional na cidade, assim como a quantidade de fogos/família e a média de pessoas por cada aglomerado familiar.

Tabela 2 - População total escrava e livre em Ribeirão Preto (1872 e 1886)

\begin{tabular}{ccccc}
\hline $\begin{array}{c}\text { População total } \\
\mathbf{1 8 7 2}\end{array}$ & $\begin{array}{c}\text { População total } \\
\mathbf{1 8 8 6}\end{array}$ & $\begin{array}{c}\text { Taxa anual de crescimento } \\
\text { populacional } \\
\mathbf{1 8 7 2 - 1 8 8 6}\end{array}$ & $\begin{array}{c}\text { Fogos* } \\
\mathbf{1 8 8 6}\end{array}$ & $\begin{array}{c}\text { Indivíduo } \\
\text { por fogo } \\
\mathbf{1 8 8 6}\end{array}$ \\
\hline 5.552 & 10.420 & 4,60 & 1.282 & 8,42 \\
\hline
\end{tabular}

*Fogos: casa, família

Fonte: BASSANEZI (1999)

A tabela 3 tem como finalidade apresentar a população total em Ribeirão Preto no ano de 1886 por grupos de idade (dividindo-se entre 1 a 5 anos completos, 6 a 15 anos completos, 16 a 30 anos completos, 31 a 50 anos completos, 51 a 70 anos completos e mais de 70 anos), sexo (feminino e masculino) e cor (dividindo-se em indivíduos considerados brancos, caboclos, pardo e pretos). Observa-se, também, que a população ribeirão-pretana de 1886 era majoritariamente jovem/adulta, de cor branca e com a razão entre sexos equilibrada.

Tabela 3 - População total segundo grupos de idade, sexo e cor em Ribeirão Preto (1886)

\begin{tabular}{|c|c|c|c|c|c|c|}
\hline \multicolumn{7}{|c|}{ Grupos de idade } \\
\hline $1-5$ & $6-15$ & $16-30$ & $31-50$ & 51-70 & Mais de 70 & Total \\
\hline 2.219 & 2.350 & 2.876 & 2.203 & 677 & 95 & 10.420 \\
\hline \multicolumn{7}{|c|}{ Sexo } \\
\hline \multicolumn{2}{|c|}{ Feminino } & \multirow{2}{*}{\multicolumn{2}{|c|}{$\begin{array}{c}\text { Masculino } \\
5.208 \\
\end{array}$}} & \multicolumn{3}{|c|}{ Total } \\
\hline \multicolumn{2}{|c|}{5.212} & & & & 10.420 & \\
\hline \multicolumn{7}{|c|}{ Cor } \\
\hline \multicolumn{2}{|c|}{ Branca } & Cabocla & Parda & \multicolumn{2}{|c|}{ Preta } & Total \\
\hline 6.73 & \multicolumn{2}{|c|}{879} & 1.508 & \multicolumn{2}{|c|}{1.301} & 420 \\
\hline
\end{tabular}

Fonte: BASSANEZI (1999)

Acompanhando as observações acerca do crescimento populacional em Ribeirão Preto, a tabela 4 tem como finalidade apresentar a média anual de nascimentos na cidade por sexo (feminino e masculino), como também apresentar a taxa de natalidade bruta em 1886. 
Tabela 4 - Média anual de nascimento segundo sexo em Ribeirão Preto (1886)

\begin{tabular}{cccc}
\hline Feminino & Masculino & Total & Taxa bruta de natalidade \\
\hline 230 & 212 & 442 & 42,2 \\
\hline \multicolumn{4}{c}{ Fonte: $B A S S A N E Z I(1999)$}
\end{tabular}

A tabela 5 tem como finalidade apresentar os dados referentes aos óbitos ocorridos em Ribeirão Preto por sexo (feminino e masculino), grupos de idade (dividindo-se por meses de idade, 1 a 5 anos completos, 6 a 15 anos completos, 16 a 30 anos completos, 31 a 50 anos completos, 51 a 70 anos completos e mais de 70 anos) e condição social (livre e escrava), também informando as taxas de mortalidade infantil e geral no referido período.

Tabela 5 - Total de óbitos segundo sexo, grupos de idade e condição social em Ribeirão Preto (1886)

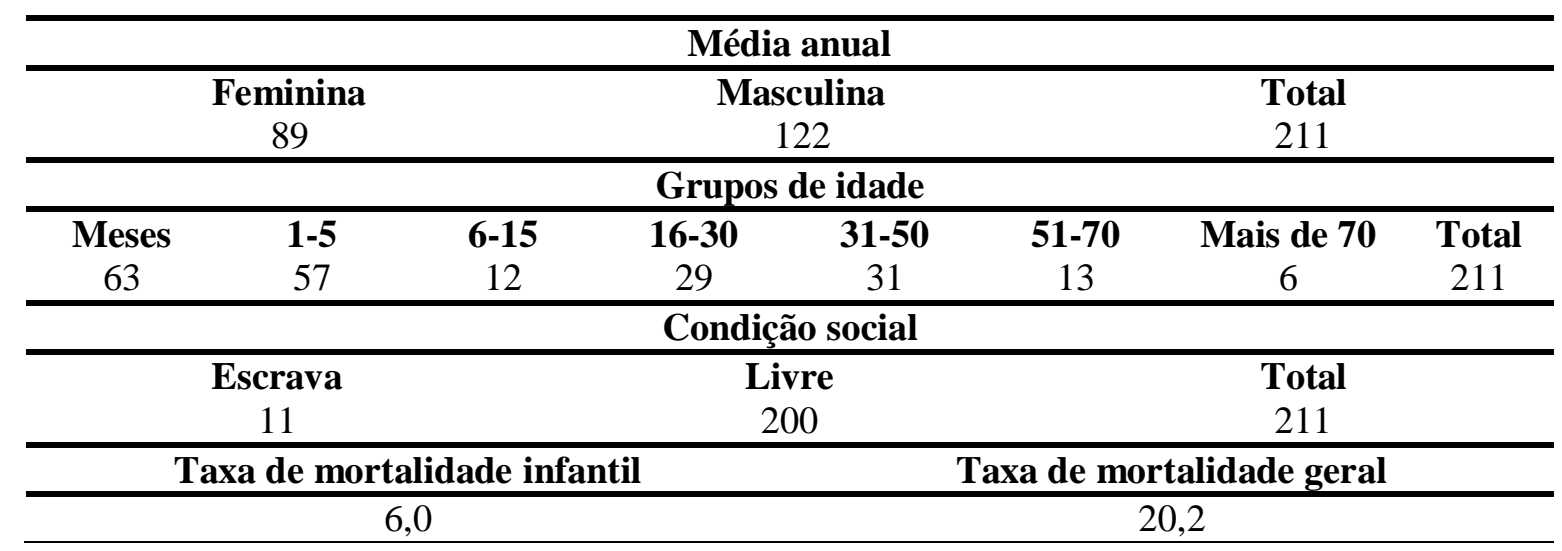

Fonte: BASSANEZI (1999)

Complementando as informações obtidas pela tabela 1 no que se refere a existência de crianças pequenas em Ribeirão Preto de 1872, pela tabela 5 é possível observar que o óbito de crianças pequenas em 1886 fora bastante elevado se comparado com os de jovens/adultos. Ainda, observa-se que o número de óbitos de pessoas com mais de 70 anos era significativamente pequeno se comparado com as outras idades. Contudo, pressupõe-se que essa pequena quantidade de óbitos de pessoas com mais de 70 anos pode ser recorrente ao fato de que poucas pessoas, principalmente as em condição de escravidão, atingiam essa idade por falta de condições básicas de sobrevivência, como alimentação e higienização adequadas.

Tratando-se especificamente da condição de escravidão em Ribeirão Preto no ano de 1886, tabela 6 tem como finalidade expressar numericamente o número de crianças livres e nascidas em ventre escravo, dividindo-se em sexo (feminino e masculino), quantidade de matrículas, averbadas por motivo de falecimento e renunciadas pelo senhor. 
Tabela 6 - Total de filhos livres de mulheres escravas segundo sexo, matrícula, averbados por motivo de falecimento e renunciados pelo senhor em Ribeirão Preto (1886)

\begin{tabular}{ccc}
\hline \multicolumn{3}{c}{ Matriculados } \\
\hline Feminino & Masculino & Total \\
235 & 211 & 446 \\
\hline \multicolumn{2}{c}{ Averbados por motivo de falecimento } \\
\hline Feminino & Masculino & Total \\
46 & 46 & 92 \\
\hline \multicolumn{4}{c}{ Renunciados pelo senhor } \\
\hline Feminino & Masculino & Total \\
0 & 0 & 0 \\
\hline
\end{tabular}

Fonte: BASSANEZI (1999)

Por conta das informações contidas na tabela 6, torna-se profícuo recordar que desde 28 de setembro de 1871, com o advento da Lei $\mathrm{n}^{\circ}$. 2.040, conhecida como Lei do Ventre Livre (BRASIL, 1871), todas as crianças nascidas em ventre escravo seriam livres após essa data. Contudo, também é relevante recordar que a situação de liberdade dessas crianças fora manipulada pela própria elaboração da lei, uma vez que no próprio texto da Lei do Ventre Livre é explicado que a criança filha de escravos deveria ficar com o senhor destes até os 8 anos de idade e, após completar tal idade, o senhor poderia optar em ficar com a criança até os 21 anos usufruindo de sua força de trabalho. Tal situação em Ribeirão Preto, pressupõe-se, pode ter ocorrido, uma vez que o número de crianças renunciadas pelo senhor é igual a zero.

A tabela 7 tem como finalidade demonstrar numericamente a população escrava matriculada até 30 de março de 1887 em Ribeirão Preto, por grupos de idade (dividindo-se em menos de 30 anos, 30 a 40 anos completos, 40 a 50 anos completos, 50 a 55 anos completos, e 55 a 60 anos completos) e por sexo (feminino e masculino).

Tabela 7 - População escrava matriculada até 30 de março de 1887 segundo grupos de idade e sexo em Ribeirão Preto

\begin{tabular}{|c|c|c|c|c|c|}
\hline \multicolumn{6}{|c|}{ Grupos de idade } \\
\hline Menos de 30 & $30-40$ & $40-50$ & $\overline{50-55}$ & $\overline{55-60}$ & Total \\
\hline 595 & 432 & 241 & 71 & 40 & 1.379 \\
\hline \multicolumn{6}{|c|}{ Sexo } \\
\hline \multicolumn{2}{|c|}{ Feminino } & \multicolumn{2}{|c|}{ Masculino } & \multicolumn{2}{|c|}{ Total } \\
\hline
\end{tabular}

Fonte: BASSANEZI (1999)

A tabela 8 tem como finalidade demonstrar os valores pelos quais os escravos em Ribeirão Preto no ano de 1886 eram comercializados, dividindo-se por grupos de idade (menos de 30 anos, 30 a 40 anos completos, 40 a 50 completos, 50 a 55 anos completos e 55 a 60 anos completos). 
Tabela 8 - Valores de escravos comercializados segundo grupos de idade em Ribeirão Preto (1886)

\begin{tabular}{cc}
\hline Grupos de idade & Valores* \\
\hline Menos de 30 & $471: 800$ \\
$30-40$ & $202: 330$ \\
$40-50$ & $130: 000$ \\
$50-55$ & $24: 875$ \\
$55-60$ & $7: 250$ \\
\hline
\end{tabular}

*Valores em réis

Fonte: BASSANEZI (1999)

Pela tabela 8 é possível constatar que conforme os escravos tornavam-se mais velhos, menor era o seu valor no comércio, ou seja, a idade era inversamente proporcional ao valor do sujeito. Pressupõe-se que essa inversão fora ocasionada não apenas pelo fator de idade em si, mas também fato de que quanto mais jovem o escravo, o senhor poderia usufruir de sua vida e força de trabalho por mais tempo e de modo mais intenso, solicitando serviços pesados e justificados pela suposta vitalidade que os escravos mais jovens teriam. Ainda, é muito importante observar que o alto valor dos escravos mais jovens também poderia ser utilizado como argumento para a ação de contratação de soldada de crianças livres nascidas em ventre livre, principalmente. Uma vez contratada, a criança serviria por cerca de dois anos até poder sacar no cofre de órfãos a quantia acumulada e paga pelo seu senhor ou então ter seu contrato renovado pelo mesmo. Contudo, conforme já discutido anteriormente, a legislação da Ventre Livre previa que o senhor poderia ficar os filhos de seus escravos e usufruir de seus serviços até que estes completassem 21 anos de idade, o que se tornaria uma saída viável para que estes mesmos senhores não tivessem necessidade em ter mais gastos na comercialização de novos escravos jovens e manter seus interesses econômicos estáveis.

Acerca de possíveis justificativas para normalizar a recorrente criação dos filhos dos outros, havia o fato de que a mentalidade vigente há tempos - e forte no século XIX considerava a mulher como subordinada ao seu marido, sendo uma excelente administradora da casa e um modelo de educação aos filhos e apenas sendo considerada digna de tanto se tivesse um homem, o provedor, ao seu lado. As crianças filhas de homens e mulheres que não se encontravam nesta moralidade regradora da vida familiar e que eram pobres deveriam ser "salvas" e encaminhadas para pessoas que lhes garantissem uma vida digna, ainda que isto significasse trabalhar para alguém em troca de casa, criação e uma incerta remuneração (BASTOS, 2012; BASTOS; KUHLMANN JR., 2009). Com isto, estava pavimentado o caminho para a tutela. Assim, com a discussão acerca da tutela e infância desvalida em Ribeirão Preto, observa-se as motivações que justificavam a criação dos filhos alheios, quer 
informalmente ou quando arbitrada pelo judiciário, como é caso da soldada e da tutela e podem ser apontadas como atuantes na região a partir do ano de 1872.

\subsubsection{O problema da infância nos periódicos ribeirão-pretanos}

Conforme já explicado no decorrer da introdução do trabalho, é de suma importância reafirmar que o desenvolvimento deste se deu a partir dos resultados obtidos através da pesquisa realizada por Cíntia Regina Czysz de Castro (2010). Explica a autora que o propósito original da pesquisa supracitada seria a investigação sobre processos judiciais, tendo como material auxiliar artigos, editoriais e notas policiais nos periódicos locais como também documentos oficiais produzidos pela administração da cidade. Assim, ao entrar em contato com o material dos periódicos, percebeu-se que tais textos traziam indícios acerca de como a imagem da menoridade pobre da cidade era divulgada a partir da retratação de mínimos delitos, comumente cometidos por meninos entre 9 e 18 anos, assim como também a partir da retratação de episódios de violência física e sexual. Já com a análise de alguns processos, observou-se apenas acerca do silenciamento dos menores quer fossem autores ou vítimas.

Castro (2010) explica dois aspectos percebidos pela análise primária dos textos selecionados nos periódicos pesquisados sobre a questão específica da menoridade em Ribeirão Preto. O primeiro é a percepção acerca das formas de manifestação da delinquência infantojuvenil na cidade por meio de ações características e/ou atribuídas aos menores, sendo estes, possivelmente, autores de agressões e pequenos furtos como também vítimas de violência física e/ou sexual e exploração pelo trabalho. O segundo aspecto é sobre como esses mesmos textos estabeleciam e qualificavam acerca de questões sobre a infância e pobreza, associando-as à delinquência.

Em relação a um possível controle realizado para sanar o problema da infância que não se enquadraria nos padrões desejados, observou-se a divulgação de possíveis intervenções, a exemplo da restrição de liberdade de menores através de internações em hospitais, hospícios e cadeias dentro e fora da cidade de Ribeirão Preto, seja por estes estarem sofrendo algum tipo de "transtorno" mental, por cometerem pequenos furtos e/ou por serem encontrados "vadiando" pela cidade", como se pode observar nas notas ${ }^{5}$ a seguir:

\footnotetext{
${ }^{5}$ Tais notas incluídas neste trabalho foram levantadas, selecionadas e transcritas por Castro (2010) na pesquisa intitulada "O discurso sobre a menoridade nos processos do judiciário em Ribeirão Preto durante a República Velha (1903-1927)".
} 
O dr. Chefe de Polícia ordenou ao Delegado desta cidade, que remettesse para S. Paulo o menor louco Victorio Frangozze residente na Companhia Dumont. (A CIDADE, 1905 , p. 2$)^{6}$.

Seguiu hontem para S. Paulo, o menor louco Antonio Frangose afim de ser internado no Hospício de Alienados por ordem do Dr. Chefe de Polícia. (A CIDADE, 1905, p. $2)^{7}$.

No momento em que subtrahia um par de patins, no estabelecimento do St. Tibiriçá Barboza, à rua General Ozorio, foi preso o pretinho Caetano Rufino, em cuja companhia se acharam dous outros menores, que conseguiram escapulir. (DIÁRIO DA MANHÃ, 1912) ${ }^{8}$.

Deu hontem entrada na cadeia desta cidade a menor Angelina Scarpini, que está soffrendo das faculdades mentaes. (DIÁRIO DA MANHÃ, 1912, p. 1).

Deu entrada na cadeia publica, por estar soffrendo das faculdades mentaes, a menor Angelina Scarpini. (A CIDADE, 1912, p. 1) ${ }^{10}$.

Vindos da Villa Bomfim, deram entrada hontem na cadeia desta cidade os menores Antonio Gonsalves de Lima e Nathalino Zumbalulis, que estão sofrendo de alienação mental. (DIÁRIO DA MANHÃ , 1913, p. 2) 211 $^{11}$

Um menor que herdou de seu pai uma chapa de mendigo, a de numero 28 , continuou no mister de pedir esmola, principalmente em Santa Thereza, onde comettia actos improprios de um <<mendigo >>, tornando-se mesmo o seu procedimento intoleravel, pelo que o chefe daquela estação se queixo á policia. A chapa foi aprehendida e o menor reprehendido. (DIÁRIO DA MANHÃ, 1913, p. 1) ${ }^{12}$.

Casos de tentativa e realização de estupro de vulnerável, comumente chamados de "defloramento" na época, também foram noticiados, a saber:

Foi remetido ao dr. Promotor Publico por intermédio do dr. Juiz de Direito o processo em que é indiciado Phellipo Pieroni, como autor da tentativa de defloramento na pessoa da menor Paschoalina Mantovani, de 4 annos e meio de idade e filha de Baptista Mantovani, morador á rua Florência de Abreu no 55. (A CIDADE, 1905, p. $1)^{13}$.

Pelo sr. Dr. Elyseu Guilherme, juiz de direito da comarca foi expedido mandado de prisão contra Raphael Marascia pelo crime de defloramento na menor Maria Megua. (A CIDADE, 1915, p. 1) $)^{14}$.

A menor Maria Buzan, residente á rua Capitão Salomão, 31, deu queixa á policia contra Francisco Chéres, acussando-o autor de seu defloramento. Chéres foi preso e será processado. (A CIDADE, 1916, p. 2) ${ }^{15}$.

\footnotetext{
${ }^{6}$ A CIDADE, ano I, 8 de fevereiro de 1905, n. 33, p. 2.

${ }^{7}$ A CIDADE, 12 de fevereiro de 1905, n. 37, p. 2.

${ }^{8}$ DIÁRIO DA MANHÃ, ano XIII, 7 de maio de 1912, n. 3873, p. não informada.

${ }^{9}$ Idem, ano XIV, 15 de junho de 1912, n. 3907, p. 1.

${ }^{10}$ A CIDADE, ano VIII, 15 de junho de 1912, n. 2363, p. 1.

${ }^{11}$ DIÁRIO DA MANHÂ,, ano XIV, 11 de janeiro de 1913, n. 4078, p. 2.

${ }^{12}$ Idem, ano XV, 13 de dezembro de 1913, n. 4338, p. 1.

${ }^{13}$ A CIDADE, ano I, 27 de janeiro de 1905, n. 23, p. 1.

${ }^{14}$ Idem, ano XI, 5 de janeiro de 1915 , n. 8277, p. 1.

${ }^{15}$ Idem, ano XII, 19 de novembro de 1916, n. 3836, p. 2.
} 
Contudo, explica Castro (2010) que crimes de ordem sexual também poderiam se configurar como um subterfúgio para o casamento, já que por vezes também seriam realizados por "casais que queriam se casar e, por algum motivo de impedimento, não podiam fazê-lo livremente, tendo de lançar mão de recursos como um quase delito de rapto ou um duvidoso 'defloramento"' (CASTRO, 2010, p. 37) a exemplo da nota a seguir:

Antonio Spinelli, italiano residente nesta cidade, raptou a menor Maria Benedicta dos Santos. Chegando este facto ao conhecimento da policia, foram raptor e raptada chamados a presença do delegado de policia, declarando ambos desejarem contrahir matrimonio pelo que foi officiado ao Juiz de Paz afim de providenciar sobre o enlace matrimonial do dois pombinhos. $\mathrm{O}$ casamento realisou-se hontem às 5 horas da tarde. (A CIDADE, 1905, p. 1) ${ }^{16}$.

Ainda, também importante observar que além da possível tentativa para contrair o matrimônio sem maiores impedimentos realizados, em sua maioria, por familiares, havia-se a necessidade da nomeação de um tutor provisório (tutela ad hoc, a saber no decorrer deste trabalho) para que este autorizasse a realização do casamento quando o responsável legal não era encontrado. Sobre os pais da menor em questão, pouco era sabido ou muito menos informado:

O dr. Delegado de policia officiou hontem ao juiz de direito, dr. Elyseu Guilherme Christiano, comunicando-lhe que se acham detidos na repartição da policia Antonio Fernandes Junior de 22 annos de edade, e Isolina Barreto de 16 annos por esse raptada no dia 12 do corrente. Não se achando actualmente nesta cidade o tutor da referida menor, pede aquella autoridade a nomeação de um tutor $\langle\langle$ ad-hoc $\rangle$, no sentido de effectuar-se o casamento. (DIÁRIO DA MANHÃ, 1912, p. 2) ${ }^{17}$.

Foi effectuado na delegacia de policia desta cidade o casamento de José Antônio Rodrigues com a menor por ele raptada Maria Josepha. (DIÁRIO DA MANHÃ, 1913, p. 1$)^{18}$.

A possível negligência para com as crianças também, por vezes, era denunciada através dos periódicos locais, seja pela informação de que um menor fora encontrado perdido pelas ruas, de que fora colocado à venda ou que estaria sendo explorado no trabalho, conforme ilustram as notas a seguir:

Da rua Amador Bueno, n. 61, communicam-nos que se acha uma menina de dois annos, ignorando-se quaes sejam os seus paes. (DIÁRIO DA MANHÃ , 1912, p. 1) ${ }^{19}$.

Chegou ao nosso conhecimento que um casal de italianos andou hontem de porta em porta offerecendo, por dez mil réis, uma creança de seis mezes, pouco mais ou menos. O facto, apesar de se nos afigurar de todo destituido de verosimilhança, deu nos que pensar. Chegamos mesmo a sahir à procura do deshumano casa. Ninguem nos soube,

\footnotetext{
${ }^{16}$ A CIDADE, ano I, 21 de janeiro de 1905, n. 18, p. 1.

${ }^{17}$ DIÁRIO DA MANHÃ, ano XIII, 15 de maio de 1912, n. 3880, p. 2.

${ }^{18}$ Idem, ano XIV, 9 de janeiro de 1913, n. 4076, p. 1.

${ }^{19}$ Idem, ano XIII, 21 de março de 1912, n. 3850, p. 1.
} 
porém, dizer do seu paradeiro. Ahi fica escripta a noticia, à qual não juntamos nenhum comentário. (DIÁRIO DA MANHÃ, 1912, p. 1) ${ }^{20}$.

Hontem á uma hora foi aprehendida uma menor que mendigava explorada pelos paes. Estes foram obrigados a comparecer á policia, que tomou as necessarias providencias. (A CIDADE, 1916, p. 1) $)^{21}$.

Ainda, o fator da negligência com os menores também sofria a intervenção do próprio noticiário local quando este indicava em suas notas a necessidade da nomeação de um tutor para uma criança que se encontrava em possível situação de abandono por ambos os pais ou então apenas órfã de pai, a exemplo das seguintes notas:

Pelas 10 horas da noite de hontem, andava por sob a chuva que cahia e completamente descoberto, em um estado de lastimosa embriaguez, em frente ao jardim uma negra maltrapilha que tinha nos braços uma creança clara, a que chamava de filha. E a negra cambaleava inspirando a todos dó e horror aquelle quadro. Um transeunte condoído da triste sorte da infeliz criancinha foi dar parte do caso na policia, que imediatamente mandou buscar os miseros. Se a negra é de facto mãe da criancinha clara, é o caso de se nomear tutor a esta. (A CIDADE, 1912, p. 1) ${ }^{22}$.

Foi encontrada hontem pela manhã, nas immediações da estação da Mogyana, uma menina de cor preta de nome Benedicta, que se achava perdida. Como não soubesse ella dizer onde morava, nem os nomes dos paes, foi pela autoridade policial depositada em uma casa do Sr. Leão Pinheiro, até que lhe seja nomeado um tutor ou proura da família. (DIÁRIO DA MANHÃ, 1913, p. 2) ${ }^{23}$.

O dr. Curador de Orphãos teve hontem denuncia de que, no bairro do Barracão, uma mulher, de cor preta, que há dois dias havia enlouquecido, se encerarava num quarto, bem como seus dois filhos menores, um de seis annos e um menina de anno e meio de idade. Soube mais o dr. Curador de Orphãos que areferida preta desde que se havia encerrado no quarto não dera mais alimento ás creanças, tentando matal-as. Em vista disso a autoridade policial enviou para lá uma pequena escolta acompanhada do escrivão conseguindo então prender a demente. As creanças ficaram depositadas, á espera da nomeação de tutores. (DIÁRIO DA MANHÃ, 1913, p. 1) ${ }^{24}$.

Contudo, nem sempre a nomeação de um tutor para tomar os cuidados de uma criança em situação de abandono e/ou risco significava que esta não seria exposta a apuros, pois os periódicos locais também denunciavam acerca de possíveis maus-tratos que esta poderia sofrer em sua nova residência, a exemplo da seguinte nota:

Ha dias a policia recebeu denuncia de que o cap. Rocha Lima, advogado do nosso fôro, residente á rua Prudente de Moraes n. 19, maltratava barbaramente uma menina de 9 a 10 annos de edade, de nome America Gertrudes que se achava entregue aos seus cuidados. [...] No dia 4 do corrente, a policia, depois de varias pesquisas encontrou a infeliz menina, que foi submettida a exame medico, apresentando inumeros ferimentos e contusões em toda parte do corpo que atestavam de um modo

\footnotetext{
${ }^{20}$ Idem, ano XIV, 12 de junho de 1912, n. 3904, p. 1.

${ }^{21}$ A CIDADE, ano XII, 19 de março de 1916, n. 3637, p. 1

22 Idem, ano VIII, 26 de março de 1912, n. 2304, p. 1.

${ }^{23}$ DIÁRIO DA MANHÃ, ano XIV, 21 de janeiro de 1913, n. 4086, p. 2.

${ }^{24}$ Idem, ano XV, 11 de julho de 1913, n. 4216, p. 1.
} 
positivo todos os supplicios que lhe infligia o seu patrão ou patrões [...]. (A CIDADE, 1912, p. 1) $)^{25}$.

Observando a situação de possíveis maus-tratos realizados pelo tutor e/ou contratante de serviços, pressupõe-se que os periódicos também que informavam acerca de fugas realizadas pelos menores:

Alfredo de tal, de 18 annos de idade, que há dias havia fugido da casa do dr. Juiz de Direito de Sertãozinho, seu tutor, foi encontrado nesta cidade pela policia, que já o enviou áquela localidade. (DIÁRIO DA MANHÃ, 1913, p. 1) ${ }^{26}$.

João Pinto, morador na fazenda Schimidt no bairro de S. Cruz de Jacques, queixou-se á autoridade policial que hontem pelas 10 horas da manhã desappareceu de sua casa uma rapariguinha de côr preta, com 16 annos de edade, e de nome Conceição, julgando que tenha encaminhado para esta cidade [...]. (A CIDADE, 1918, p. 1) ) $^{27}$.

Ainda, e não menos importante em atentar-se, os periódicos locais também se colocavam à disposição da população que buscava crianças a fim de contrai-las para prestação de serviços, como pode ser confirmado pelas seguintes notas:

Precisa-se de uma menina de 10 a 12 annos, para serviços leves, na rua Amador Bueno, 70. (DIÁRIO DA MANHÃ, 1913, p. 1) ${ }^{28}$.

Precisa-se de uma menina de 10 a 12 annos, para serviços leves, na casa n. 23, Rua Laffayete. (DIÁRIO DA MANHÃ, 1913, p. 2$)^{29}$.

Assim, com o aumento da população em Ribeirão Preto a partir da década de 1900, como também o aumento de problemas estruturais e sociais da cidade, como a infância desvalida, tais complicações foram possíveis de serem verificadas através da consulta aos periódicos A Cidade e Diário da Manhã que circulavam na cidade no referido período. Conforme observado anteriormente, alguns artigos dos periódicos denunciavam desde venda, maus tratos, abandono de crianças e até mesmo violência sexual contra as mesmas, como também notas policiais envolvendo estas, sendo que nestas a qualificação da menoridade como marginalizada surgira a partir de concepções enviesadas sobre a infância órfã, pobre e/ou abandonada em Ribeirão Preto na época pesquisada. Ainda, o aparecimento de sugestões para a nomeação de tutores nos periódicos demonstravam uma possível ação do judiciário da época, com adventos policiais e estatais, sobre o tratamento e qualificação da menoridade na cidade, uma vez que "os processos do judiciário é que vão mostrar como era a relação do estado com a questão da menoridade, já as notas de jornais mostrarão mais claramente como pensava e agia

\footnotetext{
25 A CIDADE, ano VIII, 13 de dezembro de 1912, n. 2503, p. 1.

${ }^{26}$ DIÁRIO DA MANHÃ, ano XV, 16 de julho de 1913 , n. 4220, p. 1.

${ }^{27}$ A CIDADE, ano XIV, 8 de março de 1918, n. 4443, p. 1.

${ }^{28}$ DIÁRIO DA MANHẪ, ano XIV, 11 de janeiro de 1913, n. 4078, p. 1.

${ }^{29}$ Idem, 17 de janeiro de 1913, n. 4081, p. 2.
} 
a sociedade, no caso a ribeirão-pretana, nas primeiras três décadas do século XX" (CASTRO, 2010, p. 70). É possível observar esse pensamento e ação discriminatória em relação as crianças pertencentes às camadas menos abastadas de Ribeirão Preto pelo constante uso de "termos [como] 'gatunos', 'ladrão', 'larápio', geralmente identificados como 'pretos', 'pretinho', 'pardo', 'italiano', 'português', 'rapaz', 'rapazola'” (CASTRO, 2010, p. 70). Ainda, especificamente sobre a questão da menoridade, também era frequente o uso de termos que poderiam enviesar de modo negativo a opinião dos leitores sobre as crianças e adolescentes, a exemplo do termo "menor" "como toda carga 'negativa' de sentidos que já se conhece, ora apenas como sujeito menor de idade e, às vezes, acompanhada de outros qualificadores, tal como 'louco', 'pivete', 'negrinhos', 'larápios', etc.” (CASTRO, 2010, p. 70). Com tais observações, é possível pressupor que a infância desvalida na Ribeirão Preto do final do século XIX e início do século XX também se encontrava concebida, por vezes, de modo trivial aos moldes de civilidade, progresso, controle, vigilância e punição da sociedade brasileira da época.

Sérgio César da Fonseca e Cíntia Regina Czysz de Castro (2013), explicam que o aumento demográfico experimentado por Ribeirão Preto nesse período agravou os problemas relativos às demandas da vida urbana, como moradia, emprego, saúde, assistência e abastecimento e que, consequentemente, contribuiram para agravar o problema da infância desvalida. Os autores explicam que era constante a associação entre pobreza e delinquência infanto-juvenil com crianças e adolescentes que vagavam pelas ruas da cidade. Ainda, observam sobre essa população específica complicações agravantes no que se refere a "sobrevivência devido ao custo de vida, ao aviltamento da remuneração, ao não aproveitamento da mão de obra disponível nas ocupações remuneradas" (FONSECA; CASTRO, 2013, p. 136), tendo também como um impasse a mais o fato de "haver poucas instituições para apelar por ajuda, uma vez que eram insuficientes as raras formas de assistência social" (FONSECA; CASTRO, 2013, p. 136). Assim, concluem que muitos dos elementos que eram constantemente vinculados à condição de pobreza poderiam ser utilizados como justificativa para um possível rearranjo familiar de tais crianças e adolescentes pela sociedade da época, uma vez que:

[...] trata-se de fatores que, conjugados, incidiram sobre os pobres e, por conta disso, determinaram o desprendimento de certo contingente de crianças e jovens do campo da influência da família, porque pauperizada e, por extensão, limitada no seu papel de mediar ativamente o progressivo ingresso dos filhos na vida social e, bastante importante, sem meios suficientes para amparar e suprir suas necessidades. (FONSECA; CASTRO, 2013, p. 136).

Explica Sérgio César da Fonseca (2009) que a assistência aos pobres em Ribeirão Preto dera seus primeiros sinais de existência ao final de século XIX por iniciativa privada, sendo que 
apenas nas primeiras décadas do século XX a administração da cidade tomou providências para contribuir com as pequenas ações já existentes, além de fomentar o auxílio público em tais associações particulares e de cunho religioso. Ainda, importante citar a implantação dos parques infantis como uma das iniciativas públicas para lidar com o problema da infância em Ribeirão Preto $^{30}$.

Em um estudo específico sobre a interiorização da assistência, Fonseca (2012b) reconhece que essas condições que produziram contingentes de crianças desvalidas são as mesmas que responderam por motivar em parte o estabelecimento de contratos de soldada e processos de tutela em Ribeirão Preto também entre fins do século XIX e as primeiras décadas do XX. Acrescente-se, ainda, conforme lembra o autor, que pela inexistência de instituições ou meios de assistência a quem as pessoas poderiam recorrer nesse período, não se havia criado condições em Ribeirão Preto para outras respostas contrárias além de acomodar essas crianças e adolescentes pobres em novos arranjos inter-familiares. Além disso, a tutela registra, também, o recurso de famílias ao judiciário por motivo de disputas de heranças e curatela do patrimônio de menores de idade (FONSECA, 2012b).

Em outro pequeno estudo, semelhante a este que se apresenta e que também auxiliou em sua fundamentação, Fonseca (2012a) expõe as possíveis motivações para que a prática da tutela se tornasse frequente entre pessoas da própria família e por indivíduos sem quaisquer vínculos de parentesco, tendo suas demandas arbitradas pelo judiciário. A primeira delas seria o conflito de interesses no que se refere à partilha e administração de bens dos menores, tendo apenas o pai como falecido, sendo esta ação beneficiada pelo pátrio poder. Outra demanda averiguada como possivelmente arbitrária seria o interesse em ter o reconhecimento legal da responsabilidade de criação dessas crianças filhas de parentes já falecidos, ou seja, ter, na letra da lei, total e completo direito não somente pela criança, mas também pelos seus bens herdados e patrimônio. Ainda, e não menos importante, há a questão do posicionamento secundário da mulher como responsável pela criação dos filhos pela legislação vigente no período estudado (FONSECA, 2012a).

Observa-se que a Ribeirão Preto do passado se apresentava de modo paradoxal: ainda que a cidade procurasse se mostrar em busca da modernidade devido os ares de progresso proporcionados por sua estrutura arquitetônica e agitada vida noturna, tendo seu ápice urbano pelo apogeu da cafeicultura, também é possível observar que essa mesma cidade usufruía como fonte de progresso e crescimento social, econômico e político o trabalho escravo e a apropriação

\footnotetext{
${ }^{30}$ Cf. Prandi (2015); Menengotti-Ferreira (2016).
} 
da infância de crianças desvalidas, sendo estas reduzidas a meras informações contidas em solicitações e depoimentos de senhores nos autos de tutela e contratos de soldada levantados para o desenvolvimento dessa pesquisa. Ribeirão Preto, ainda que se encontrasse em uma busca incessante pelo progresso social, econômico e político, não fez questão de romper com seus traços coronelistas (existentes na cidade antes mesmo da Primeira República) para atingir a modernidade como um todo. Com isso, pressupõe-se que a observação de modo profícuo ao tratamento e qualificação da infância desvalida na cidade, a partir das intervenções realizadas pelo judiciário da época, poderá contribuir para a compreensão da Ribeirão Preto do passado, como até mesmo, talvez, realizar inferências com seu desenvolvimento e manutenção social na atualidade.

\subsection{Metodologia e organização dos dados coletados nos processos judiciais ribeirão- pretanos (1872-1917)}

Tomando os processos judiciais de tutela e soldada como principal corpus documental da pesquisa, a elaboração dos procedimentos metodológicos que foram utilizados na coleta de dados fora efetuada de forma meticulosa, considerando o estudo da composição e organização do material como o primeiro passo a ser realizado. Esse estudo acerca da composição e organização dos processos foi essencial para delimitar o que, de fato, deveria ser investigado nos documentos, pois segundo Antônio Joaquim Severino (2007, p. 123), na pesquisa documental "os conteúdos dos textos ainda não tiveram nenhum tratamento analítico, são ainda matéria-prima, a partir da qual o pesquisador vai desenvolver sua investigação e análise”.

Assim, além do levantamento preliminar dos processos para que se pudesse entrar em contato com estes e observar como tais estavam dispostos, buscou-se em trabalhos que também utilizaram a mesma fonte de pesquisa e com objetivos similares possíveis referências sobre como realizar um procedimento metodológico que focasse no objetivo deste trabalho. Com isto, encontrou-se nos trabalhos de Gislane Campos Azevedo (1995), Arethuza Helena Zero (2004), Alessandra Zorzeto Moreno (2007), Lívia Maria Botin (2007), Ana Cristina do Canto Lopes Bastos (2012) e Marília Bueno de Araújo Ariza (2015) referências metodológicas no tratamento de processos de tutela e soldada, assim como possíveis categorias de análise de acordo com os objetivos de cada pesquisa. Ainda, especificamente nos trabalhos de Azevedo (1995), Zero (2004), Botin (2007) e Bastos (2012), como também durante o levantamento preliminar de fontes, descobriu-se outros tipos de documentos, além da tutela e soldada, que se relacionavam com o corpus documental principal e com o objetivo do trabalho. Esses outros documentos que 
também foram incluídos no interesse da pesquisa são processos acerca de situações que tratavam de apreensão, prestação de contas de soldada, prestação de contas de pessoa e bens, remoção de tutor e remoção de contratante ${ }^{31}$. Encontrou-se também nos trabalhos de Rafael De Tilio $(2005 ; 2009)$ orientações acerca do tratamento de processos, sendo que as fontes utilizadas pelo autor foram processos crimes e judiciais que tratavam acerca de casamentos e crimes sexuais em Ribeirão Preto entre as décadas de 1870 e 1970.

Após o reconhecimento das fontes de pesquisa, leitura preliminar de alguns processos e tendo como referência o tratamento do mesmo tipo de documentos em outros trabalhos já finalizados, observou-se que a organização destes é variável. A maioria dos processos selecionados têm capa, na qual comumente encontra-se em sua parte superior o ano de abertura da ação, o instituto jurídico responsável pelo processo e local de abertura, descrição da ação do processo, os nomes do requerente e requerido, e, por vezes, o do escrivão responsável pela escrita do processo. Na parte central e que vai até a inferior da capa, encontra-se uma espécie de certidão, na qual se reitera as informações já descritas na parte superior.

A composição interna dos processos selecionados varia de acordo com o motivo de abertura, mas a grande maioria é iniciada pela petição inicial. A petição inicial organiza-se da seguinte forma: na parte superior, em sua maioria, encontra-se um cabeçalho no qual é indicado para qual figura jurídica a petição inicial fora encaminhada, comumente enviada ao Juiz de Órfãos, sendo que este poderia realizar, posteriormente, anotações nesse mesmo espaço para informar que tomou conhecimento do documento e solicitando o encaminhamento do caso para o Curador Geral de Órfãos, especificando local e data e, por fim, assinando-o. Contudo, a depender do que fora solicitado na petição inicial, o restante dos documentos incluídos no processo serão de acordo com o pedido, a exemplo de solicitações de tutela nas quais observouse uma disputa judicial entre o requerente a tutor e a mãe da criança alvo. Nestes casos, foram incluídas folhas as quais trazem depoimentos coletados acerca de uma pressuposta má conduta da mãe para fomentar a solicitação da tutela pelo requerente, como também apelações da própria mãe, também trazendo maiores informações sobre os motivos pelos quais a criança deveria ficar com esta.

Também, em processos os quais tratam da prestação de contas de pessoa e bens pelo tutor foram incluídos comprovantes da administração do dinheiro e patrimônio das crianças tuteladas, como, por exemplo, folhas de pagamento de funcionários de fazendas ou do recebimento de aluguéis de casas herdadas. Contudo, observou-se que foram poucos os

\footnotetext{
${ }^{31}$ Tais nomeações foram elaboradas pela autora da pesquisa apresentada de acordo com o conteúdo descrito nas petições iniciais examinadas, com vistas a organizar e sistematizar os processos selecionados.
} 
processos de contrato de soldada em que foram incluídas maiores informações acerca da quantia que seria paga para as crianças, como também o tipo de serviço que estas deveriam realizar, além da falta de comprovantes do depósito da soldada no cofre dos órfãos. A maioria destes documentos, quando incluídos no processo, trazem local e data, como também a figura jurídica responsável pela ação, podendo ser o Juiz de Órfãos, o Curador Geral de Órfãos, os advogados que, por vezes, representavam os requerentes ou os requeridos e o escrivão responsável pela escrita do processo.

Isto posto, tomou-se como foco a leitura e análise da capa do processo, a qual contém informações já descritas anteriormente, como também a leitura e análise da petição inicial. $\mathrm{Na}$ petição inicial, além de também encontrar as informações já obtidas pela leitura e análise da capa, pode-se verificar mais informações sobre o indivíduo suplicado/requerido (quando criança: descrição da cor, idade, se era órfão e se possuía algum bem material), como também as motivações que levaram o suplicante/requerente a abrir o processo.

O seguinte procedimento realizado e muito importante para selecionar os processos que interessavam ao desenvolvimento do trabalho foi a consulta ao catálogo do Fundo "Processos Antigos" que, de acordo com os funcionários do APHRP, é onde se encontram os tipos de processos necessários e que se referem ao período pesquisado. O quadro 1 simula como está organizado o catálogo citado anteriormente:

Quadro 1 - Simulação do catálogo referente ao Fundo "Processos Antigos" disposto pelo Arquivo Público e Histórico de Ribeirão Preto

\begin{tabular}{|c|c|c|c|c|c|c|c|}
\hline Caixa & Data & Ação & $\begin{array}{c}\text { Autor/Requerente/ } \\
\text { Inventariante }\end{array}$ & $\begin{array}{c}\text { Réu/Executado/Inventariado/ } \\
\text { Requerido }\end{array}$ & $\begin{array}{c}\text { Paciente/ } \\
\text { Vítima }\end{array}$ & Cartório & Proc. N./Obs. \\
\hline $30-A$ & 1889 & $\begin{array}{c}\text { Prestação de } \\
\text { Contas dos } \\
\text { Serviços do } \\
\text { órfão Antero }\end{array}$ & $\begin{array}{c}\text { Fabiano Alves } \\
\text { Barbosa e Silva }\end{array}$ & $\begin{array}{c}\text { O curador [? - ilegível] do } \\
\text { órfão }\end{array}$ & $\begin{array}{c}1^{\circ} \text { Ofício } \\
\text { Cível }\end{array}$ & \\
\hline $32-A$ & & $\begin{array}{r}\text { Felisberto Ferreira } \\
\text { Gandra }\end{array}$ & $\begin{array}{c}\text { Luciano, menor filho de } \\
\text { Cecília }\end{array}$ & & & \\
\hline $50-A$ & 1896 & & Angelo Mozzuca & Luize Antonio & & & $\begin{array}{c}\text { Faltando } \\
\text { páginas }\end{array}$ \\
\hline 135-A & 1905 & & Lourenço José Rita & $\begin{array}{c}\text { Antonio José da Costa } \\
\text { Braga }\end{array}$ & $\begin{array}{c}\text { Deolinda } \\
\text { (menor) }\end{array}$ & & \\
\hline
\end{tabular}

Fonte: Arquivo Público e Histórico de Ribeirão Preto 
Contudo, ao entrar em contato com o catálogo organizado pelo APHRP, observou-se que não havia uma padronização na descrição de ação dos processos arquivados, como por exemplo, o fato de que os processos de contrato de soldada poderiam ser descritos como locação de serviços. Ainda, observou-se que nessa catalogação o APHRP apenas transcreveu exatamente as informações que constam nas capas dos processos e compreendeu-se que essa não padronização na organização dos processos equivale-se ao antigo processo de organização dos documentos durante o período em que foram produzidos. Assim, durante a leitura e análise do catálogo, buscou-se nas descrições de ação e em outros campos pistas acerca do possível conteúdo do processo, priorizando-se as descrições que continham palavras como órfão e menor, por exemplo. Constatado isso, passou-se para um levantamento mais preciso acerca dos processos que, possivelmente, se encaixariam nos critérios de seleção para a pesquisa. Mais de 100 caixas foram consultadas e cerca de 210 processos foram examinados, chegando-se ao número final de 171 processos referentes a tutela, contrato de soldada, apreensão, prestação de contas de soldada, prestação de contas de pessoa e bens, remoção de tutor e remoção de contratante, distribuídos em 86 caixas.

Concomitantemente a verificação dos processos, foram elaborados critérios para a análise dos mesmos, coletando dados que interessavam para o desenvolvimento da pesquisa e que foram organizados em uma tabela com os seguintes campos: caixa $n^{o}$. (número da caixa onde o processo está arquivado e organizado pelo APHRP); data da petição inicial (usualmente escrita ao final da petição inicial e que pode ser anterior à data que consta na capa do processo); última data que consta no processo (que pode não referir-se, necessariamente, ao encerramento do processo); descrição original de ação (a qual refere-se a descrição original da ação solicitada via processo feita pelo escrivão que consta na capa); tipo de ação (a qual refere-se a verdadeira natureza da ação solicitada via processo após a leitura da petição inicial); suplicante/requerente (indivíduo que solicitava a abertura do processo); suplicado/requerido (indivíduo alvo do suplicante/requerente); agentes oficiais atuantes no processo (podendo ser Juiz de Direito, Curador Geral de Órfãos, Escrivães e até mesmo Delegados de Polícia); na petição inicial consta a profissão do suplicante/requerente? Se sim, qual?; número de crianças/jovens do sexo feminino no processo; número de crianças/jovens do sexo masculino no processo; número de crianças/jovens de sexo não identificado no processo; na petição inicial consta a cor da criança/jovens? Se sim, qual?; na petição inicial o consta a cor da mãe elou do pai da criança/jovem? Se sim, qual?; na petição inicial consta a idade da criança/jovem? Se sim, qual?; motivação/causa para abertura do processo; e outras informações relevantes. 
Entretanto, é importante informar que nem todas as informações obtidas pela coleta de dados foram alvos de análise individual, uma vez que a obtenção de certos dados apenas fora realizada a fim de registro e/ou para complementar outros dados que foram priorizados nas análises. Ainda, optou-se em explanar os dados numéricos obtidos através coleta citada anteriormente nesse momento do texto para que o leitor do trabalho possa atentar-se aos aspectos históricos e sociais que serão abordados nos próximos capítulos.

Tomando as informações obtidas por meio do campo tipo de ação, chegou-se a quantidade de cada processo produzido de acordo com seu conteúdo e ano, a saber: 
Tabela 9 - Quantidade de processos por tipo de ação produzidos entre 1872-1917

\begin{tabular}{|c|c|c|c|c|c|c|c|c|c|c|c|c|c|c|c|c|c|}
\hline Ano & Apreensão & $\begin{array}{c}\text { Contrato de } \\
\text { soldada }\end{array}$ & $\begin{array}{c}\text { Prestação } \\
\text { de contas de } \\
\text { pessoa e } \\
\text { bens }\end{array}$ & $\begin{array}{c}\text { Prestação } \\
\text { de contas de } \\
\text { soldada }\end{array}$ & $\begin{array}{l}\text { Remoção de } \\
\text { tutor }\end{array}$ & $\begin{array}{c}\text { Tutela } a d \\
\text { hoc }\end{array}$ & $\begin{array}{l}\text { Tutela } \\
\text { dativa }\end{array}$ & $\begin{array}{c}\text { Tutela } \\
\text { legítima }\end{array}$ & $\begin{array}{c}\text { Prestação de } \\
\text { contas de } \\
\text { pessoa e bens } \\
\text { + Remoção de } \\
\text { tutor }\end{array}$ & $\begin{array}{c}\text { Prestação de } \\
\text { contas de } \\
\text { soldada + } \\
\text { Remoção de } \\
\text { contratante }\end{array}$ & $\begin{array}{c}\text { Remoção de } \\
\text { tutor + } \\
\text { Apreensão }\end{array}$ & $\begin{array}{l}\text { Remoção de } \\
\text { tutor + Tutela } \\
\text { ad hoc }\end{array}$ & $\begin{array}{c}\text { Remoção de } \\
\text { tutor + Tutela } \\
\text { dativa }\end{array}$ & $\begin{array}{c}\text { Remoção de } \\
\text { tutor + Tutela } \\
\text { dativa }+ \\
\text { Prestação de } \\
\text { contas de } \\
\text { pessoa e bens } \\
\end{array}$ & $\begin{array}{c}\text { Remoção de } \\
\text { tutor + Tutela } \\
\text { legítima }\end{array}$ & $\begin{array}{c}\text { Tutela } \\
\text { legítima + } \\
\text { Apreensão }\end{array}$ & Total \\
\hline 1872 & 0 & 0 & 0 & 0 & 0 & 0 & 1 & 0 & 0 & 0 & 0 & 0 & 0 & 0 & 0 & 0 & 1 \\
\hline 1874 & 0 & 1 & 0 & 0 & 0 & 0 & 0 & 0 & 0 & 0 & 0 & 0 & 0 & 0 & 0 & 0 & 1 \\
\hline 1876 & 0 & 0 & 0 & 0 & 0 & 0 & 0 & 0 & 0 & 0 & 0 & 0 & 1 & 0 & 0 & 0 & 1 \\
\hline 1886 & 0 & 0 & 0 & 0 & 0 & 0 & 1 & 1 & 0 & 0 & 0 & 0 & 0 & 0 & 0 & 0 & 2 \\
\hline 1889 & 1 & 0 & 2 & 2 & 2 & 0 & 6 & 0 & 0 & 0 & 0 & 0 & 1 & 0 & 0 & 0 & 14 \\
\hline 1890 & 0 & 11 & 0 & 5 & 0 & 0 & 3 & 1 & 0 & 0 & 0 & 1 & 0 & 0 & 0 & 0 & 21 \\
\hline 1891 & 2 & 3 & 0 & 0 & 0 & 0 & 1 & 0 & 0 & 0 & 0 & 0 & 0 & 0 & 0 & 0 & 6 \\
\hline 1892 & 1 & 2 & 0 & 0 & 1 & 0 & 1 & 1 & 0 & 0 & 0 & 0 & 0 & 0 & 1 & 0 & 7 \\
\hline 1893 & 0 & 0 & 0 & 0 & 1 & 0 & 0 & 1 & 0 & 0 & 0 & 0 & 0 & 0 & 0 & 0 & 2 \\
\hline 1894 & 2 & 0 & 0 & 0 & 0 & 0 & 3 & 1 & 0 & 0 & 0 & 0 & 0 & 1 & 0 & 0 & 7 \\
\hline 1895 & 0 & 0 & 0 & 0 & 0 & 1 & 3 & 0 & 0 & 0 & 0 & 0 & 0 & 0 & 0 & 0 & 4 \\
\hline 1896 & 1 & 0 & 0 & 0 & 1 & 0 & 1 & 0 & 0 & 0 & 0 & 0 & 0 & 0 & 0 & 0 & 3 \\
\hline 1898 & 1 & 0 & 0 & 0 & 0 & 0 & 1 & 0 & 0 & 0 & 0 & 0 & 0 & 0 & 0 & 0 & 2 \\
\hline 1899 & 2 & 1 & 0 & 0 & 0 & 0 & 0 & 1 & 0 & 0 & 0 & 0 & 0 & 0 & 0 & 0 & 4 \\
\hline 1900 & 0 & 0 & 0 & 0 & 0 & 0 & 1 & 1 & 0 & 0 & 0 & 0 & 0 & 0 & 0 & 0 & 2 \\
\hline 1901 & 0 & 0 & 0 & 0 & 0 & 0 & 2 & 0 & 0 & 0 & 1 & 0 & 0 & 0 & 0 & 0 & 3 \\
\hline 1902 & 1 & 1 & 0 & 0 & 0 & 0 & 3 & 0 & 0 & 0 & 0 & 0 & 0 & 0 & 0 & 0 & 5 \\
\hline 1903 & 0 & 0 & 0 & 0 & 1 & 0 & 4 & 1 & 0 & 0 & 0 & 0 & 0 & 0 & 0 & 0 & 6 \\
\hline 1904 & 0 & 0 & 0 & 0 & 0 & 0 & 1 & 1 & 0 & 0 & 0 & 0 & 0 & 0 & 0 & 0 & 2 \\
\hline 1905 & 1 & 0 & 1 & 0 & 0 & 0 & 4 & 4 & 0 & 0 & 0 & 0 & 0 & 0 & 0 & 0 & 10 \\
\hline 1906 & 2 & 0 & 0 & 0 & 0 & 0 & 3 & 2 & 0 & 0 & 0 & 0 & 0 & 0 & 0 & 0 & 7 \\
\hline 1907 & 0 & 0 & 1 & 0 & 0 & 1 & 1 & 1 & 0 & 0 & 0 & 0 & 0 & 0 & 0 & 0 & 4 \\
\hline 1908 & 0 & 0 & 0 & 0 & 0 & 1 & 2 & 2 & 0 & 0 & 0 & 0 & 0 & 0 & 0 & 0 & 5 \\
\hline 1909 & 0 & 0 & 0 & 0 & 0 & 0 & 2 & 0 & 0 & 0 & 0 & 0 & 0 & 0 & 0 & 1 & 3 \\
\hline 1910 & 1 & 0 & 2 & 0 & 0 & 0 & 7 & 1 & 0 & 0 & 0 & 0 & 0 & 0 & 0 & 0 & 11 \\
\hline 1911 & 0 & 0 & 0 & 0 & 1 & 2 & 2 & 0 & 0 & 0 & 0 & 1 & 0 & 0 & 0 & 0 & 6 \\
\hline 1912 & 0 & 0 & 0 & 0 & 0 & 0 & 2 & 1 & 0 & 0 & 0 & 0 & 0 & 0 & 0 & 0 & 3 \\
\hline 1913 & 0 & 0 & 0 & 0 & 0 & 0 & 3 & 0 & 0 & 0 & 0 & 0 & 0 & 0 & 0 & 0 & 3 \\
\hline 1914 & 0 & 1 & 1 & 0 & 0 & 3 & 2 & 1 & 0 & 0 & 0 & 0 & 0 & 0 & 0 & 0 & 8 \\
\hline
\end{tabular}

Fonte: elaborada pela própria autora 
Observa-se que nos anos de 1873, 1875, 1877, 1878, 1879, 1880, 1881, 1882, 1883, 1884, 1885, 1887 não foi encontrado nenhum processo que se encaixasse aos critérios da pesquisa. Ainda, em 1890 foi produzido o maior número de processos por ano, sendo que dos 21 processos, 11 processos tiveram como tipo de ação a contratação de serviços de crianças/jovens, 5 processos acerca da prestação de contas desse tipo de serviço, 3 processos de tutela dativa, 1 processo de tutela legítima e 1 processo de remoção de tutor seguido de tutela ad hoc. Ainda, explicitando a quantidade de processos de acordo com seu tipo de ação, entre os anos de 1872 e 1917 foram produzidos 15 processos de apreensão, 20 processos de contrato de soldada, 12 processos de prestação de contas de pessoa e bens, 8 processos de prestação de contas de soldada, 7 processos de remoção de tutor, 8 processos de tutela ad hoc, 67 processos de tutela dativa, 24 processos de tutela legítima, 1 processo de prestação de contas seguido de remoção de tutor, 1 processo de prestação de contas de soldada seguido de remoção de contratante, 1 processo de remoção de tutor seguido de apreensão, 2 processos de remoção de tutor seguido de tutela ad hoc, 2 processos de remoção de tutor seguido de tutela dativa, 1 processo de remoção de tutor seguido de tutela dativa e prestação de contas de pessoa e bens, 1 processo de remoção de tutor seguido de tutela legítima e 1 processo de tutela legítima seguido de apreensão, totalizando os 171 processos selecionados.

Por fim, e de acordo com essa estruturação dos dados coletados, foi possível seguir para a última etapa dos procedimentos metodológicos para o desenvolvimento do estudo, a qual compreendeu em buscar nesses 171 processos possíveis indicações de: 1) fundamentação jurídica nas motivações/causa para abertura do processo por meio do suplicante/requerente; 2) se a presença ou não dessa fundamentação jurídica foi determinante ou não para o deferimento da solicitação realizada pelo suplicante/requerente.

O gráfico 2 tem como finalidade demonstrar a quantidade de crianças/jovens presentes nos 171 processos selecionados, tanto em sua totalidade, quanto de acordo com o tipo de ação e dividindo-se em sexo feminino, sexo masculino e sexo não identificado: 


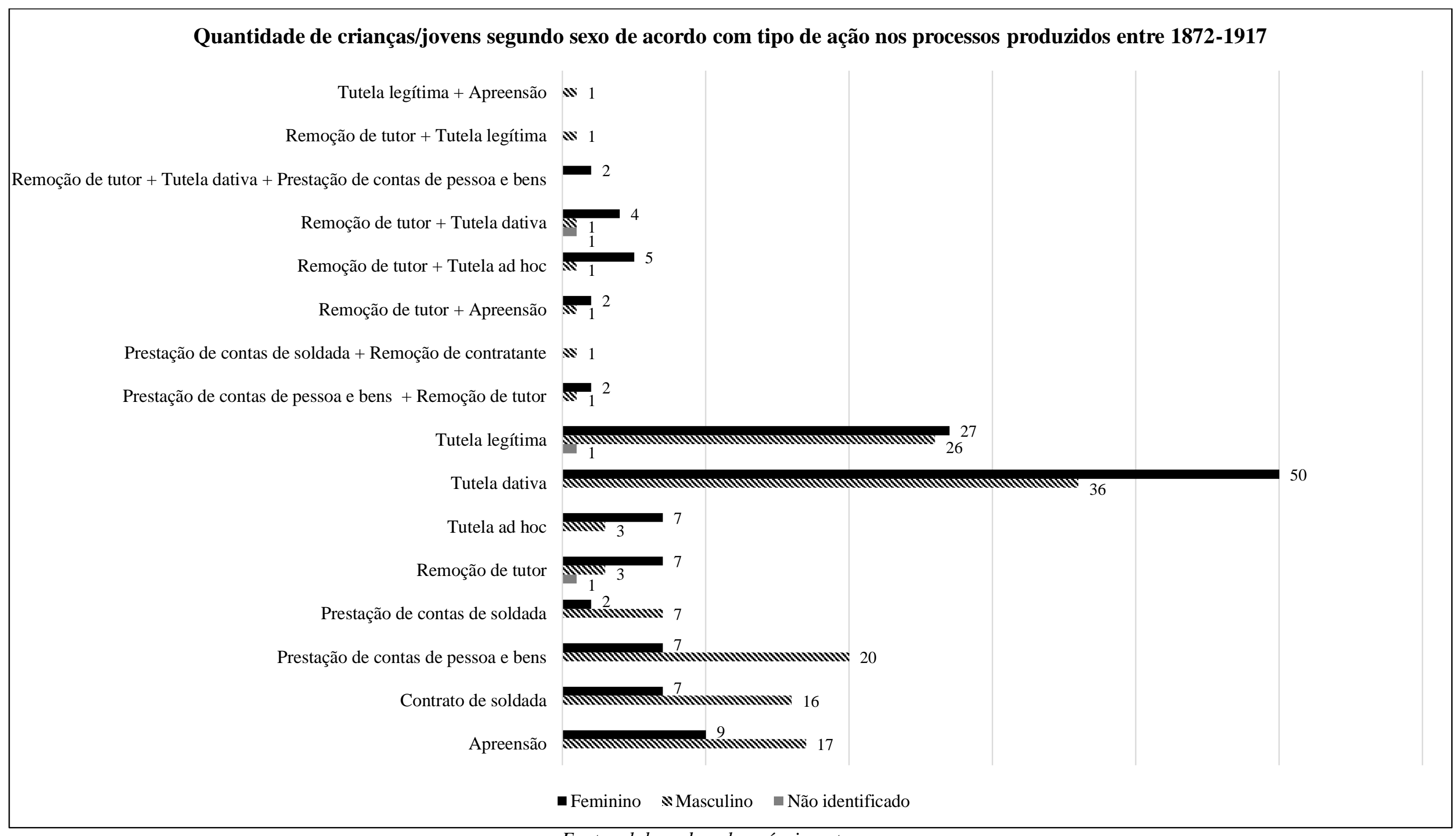

Fonte: elaborada pela própria autora 
Observa-se que ao se considerar apenas o sexo identificado, crianças/jovens do sexo masculino foram os maiores alvos dos processos selecionados. Ainda, é necessário ressaltar a informação de que era comum a presença de mais de uma criança/jovem por processo, como também o fato de que algumas crianças/jovens foram requeridas em mais de um processo. Logo, o total encontrado de 269 crianças/jovem é de acordo com a quantidade de processos levantados.

Em relação a indicação de idade das crianças/jovens, é importante informar que tal ocorreu em 97 processos. A tabela 10 tem por finalidade demonstrar quais idades/períodos de vida foram indicados nesses 97 processos, considerando o tipo de ação e dividindo-se por sexo feminino e sexo masculino, sendo que não foi encontrado nenhuma indicação de idade em processos onde o sexo da criança/jovem não foi possível de ser identificado. É necessário ressaltar que as informações explicitadas foram obtidas após o cruzamento de dados entre os processos que indicavam idade/períodos de vida da criança/jovem com o tipo de ação dos processos. Ainda, as idades/períodos de vida que aparecem na tabela a seguir foram organizadas de acordo como tal descrição foi realizada nos processos em que constavam essa informação. 
Tabela 10 - Quantidade de crianças/jovens segundo sexo e idade/período de vida indicados nos processos por tipo de ação

\begin{tabular}{|c|c|c|c|c|c|c|c|c|c|c|c|c|c|c|c|c|c|c|c|c|c|c|c|c|c|c|c|c|c|c|c|c|c|c|c|c|c|c|c|c|c|c|c|c|c|c|}
\hline \multirow[b]{2}{*}{$\begin{array}{l}\text { Apreensão } \\
7 \text { processos }\end{array}$} & \multicolumn{2}{|c|}{$\begin{array}{l}\text { Recém- } \\
\text { nascido }\end{array}$} & \multicolumn{2}{|c|}{$\begin{array}{l}\text { Criança } \\
\text { de mês }\end{array}$} & \multicolumn{2}{|c|}{ Impúberes } & \multicolumn{2}{|c|}{2} & \multicolumn{2}{|c|}{3} & \multicolumn{2}{|c|}{4} & & \multicolumn{2}{|c|}{6} & \multicolumn{2}{|l|}{7} & \multicolumn{2}{|l|}{8} & \multicolumn{2}{|c|}{9} & \multicolumn{2}{|c|}{10} & \multicolumn{2}{|c|}{11} & \multicolumn{2}{|c|}{-12} & \multicolumn{2}{|c|}{12} & \multicolumn{2}{|c|}{13} & \multicolumn{2}{|c|}{14} & \multicolumn{2}{|c|}{15} & 10 & & 17 & & 18 & & 19 & & 20 & \\
\hline & 0 & 0 & 0 & 0 & 0 & 0 & 0 & 0 & 0 & 0 & 1 & 0 & 0 & 1 & 1 & 0 & 0 & 1 & 0 & 1 & 0 & 1 & 0 & 1 & 1 & 0 & 0 & 0 & 0 & 1 & 1 & 0 & 0 & 0 & 0 & 1 & 0 & 0 & 0 & 0 & 1 & 0 & 0 & 0 & 0 & 0 \\
\hline $\begin{array}{c}\text { Contrato de soldada } \\
15 \text { processos }\end{array}$ & 0 & 0 & 0 & 0 & 0 & 0 & 0 & 0 & 0 & 0 & 0 & 1 & 0 & 0 & 0 & 0 & 0 & 1 & 2 & 0 & 0 & 2 & 0 & 4 & 0 & 1 & 0 & 0 & 2 & 2 & 0 & 1 & 0 & 1 & 0 & 0 & 0 & 0 & 0 & 0 & 0 & 0 & 0 & 0 & 0 & 0 \\
\hline $\begin{array}{c}\text { Prestação de contas } \\
\text { de pessoa e bens } \\
1 \text { processo } \\
\end{array}$ & 0 & 0 & 0 & 0 & 0 & 0 & 0 & 0 & 0 & 0 & 0 & 0 & 0 & 0 & 0 & 0 & 0 & 0 & 0 & 0 & 0 & 0 & 0 & 0 & 0 & 0 & 0 & 0 & 0 & 0 & 0 & 0 & 0 & 0 & 0 & 0 & 0 & 0 & 0 & 1 & 0 & 0 & 0 & 0 & 0 & 0 \\
\hline $\begin{array}{c}\text { Prestação de contas } \\
\text { de soldada } \\
4 \text { processos } \\
\end{array}$ & 0 & 0 & 0 & 0 & 0 & 0 & 0 & 0 & 0 & 0 & 0 & 0 & 0 & 0 & 0 & 0 & 0 & 0 & 0 & 0 & 0 & 0 & 0 & 0 & 1 & 0 & 0 & 0 & 0 & 0 & 0 & 1 & 0 & 1 & 0 & 1 & 0 & 1 & 0 & 0 & 0 & 0 & 0 & 0 & 0 & 0 \\
\hline $\begin{array}{c}\text { Remoção de tutor } \\
4 \text { processos }\end{array}$ & 0 & 0 & 0 & 0 & 0 & 0 & 0 & 0 & 0 & 0 & 0 & 0 & 0 & 0 & 1 & 0 & 0 & 0 & 0 & 0 & 0 & 0 & 0 & 1 & 0 & 0 & 0 & 0 & 0 & 0 & 0 & 0 & 1 & 1 & 0 & 0 & 0 & 0 & 0 & 0 & 0 & 0 & 0 & 0 & 0 & 1 \\
\hline $\begin{array}{c}\text { Tutela ad hoc } \\
4 \text { processos }\end{array}$ & 0 & 0 & 0 & 0 & 0 & 0 & 0 & 0 & 0 & 0 & 0 & 0 & 0 & 0 & 0 & 0 & 0 & 0 & 0 & 0 & 0 & 0 & 0 & 0 & 0 & 0 & 0 & 0 & 0 & 0 & 0 & 0 & 1 & 0 & 0 & 0 & 1 & 0 & 0 & 0 & 2 & 0 & 0 & 0 & 0 & 0 \\
\hline $\begin{array}{l}\text { Tutela dativa } \\
48 \text { processos }\end{array}$ & 1 & 0 & 1 & 0 & 0 & 0 & 2 & 3 & 1 & 1 & 0 & 0 & 0 & 1 & 3 & 0 & 2 & 1 & 4 & 1 & 3 & 1 & 4 & 2 & 4 & 0 & 1 & 3 & 2 & 2 & 2 & 2 & 0 & 2 & 0 & 1 & 2 & 1 & 1 & 1 & 2 & 0 & 3 & 0 & 0 & 0 \\
\hline $\begin{array}{l}\text { Tutela legítima } \\
10 \text { processos }\end{array}$ & 0 & 0 & 0 & 0 & 0 & 0 & 0 & 0 & 0 & 1 & 0 & 2 & 0 & 0 & 0 & 1 & 0 & 1 & 0 & 1 & 0 & 0 & 0 & 2 & 0 & 0 & 0 & 0 & 1 & 0 & 0 & 0 & 0 & 0 & 0 & 0 & 0 & 0 & 1 & 0 & 0 & 0 & 1 & 0 & 0 & 0 \\
\hline $\begin{array}{c}\text { Remoção de tutor }+ \\
\text { Apreensão } \\
1 \text { processo } \\
\end{array}$ & 0 & 0 & 0 & 0 & 2 & 1 & 0 & 0 & 0 & 0 & 0 & 0 & 0 & 0 & 0 & 0 & 0 & 0 & 0 & 0 & 0 & 0 & 0 & 0 & 0 & 0 & 0 & 0 & 0 & 0 & 0 & 0 & 0 & 0 & 0 & 0 & 0 & 0 & 0 & 0 & 0 & 0 & 0 & 0 & 0 & 0 \\
\hline $\begin{array}{c}\text { Remoção de tutor }+ \\
\text { Tutela dativa }+ \\
\text { Prestação de contas } \\
\text { de pessoa e bens } \\
1 \text { processo } \\
\end{array}$ & 0 & 0 & 0 & 0 & 0 & 0 & 0 & 0 & 0 & 0 & 0 & 0 & 0 & 0 & 0 & 0 & 0 & 0 & 0 & 0 & 0 & 0 & 1 & 0 & 0 & 0 & 0 & 0 & 0 & 0 & 0 & 0 & 1 & 0 & 0 & 0 & 0 & 0 & 0 & 0 & 0 & 0 & 0 & 0 & 0 & 0 \\
\hline $\begin{array}{c}\text { Remoção de tutor }+ \\
\text { Tutela legítima } \\
1 \text { processo } \\
\end{array}$ & 0 & 0 & 0 & 0 & 0 & 0 & 0 & 0 & 0 & 1 & 0 & 0 & 0 & 0 & 0 & 0 & 0 & 0 & 0 & 0 & 0 & 0 & 0 & 0 & 0 & 0 & 0 & 0 & 0 & 0 & 0 & 0 & 0 & 0 & 0 & 0 & 0 & 0 & 0 & 0 & 0 & 0 & 0 & 0 & 0 & 0 \\
\hline $\begin{array}{c}\text { Tutela legítima + } \\
\text { Apreensão } \\
1 \text { processo } \\
\end{array}$ & 0 & 0 & 0 & 0 & 0 & 0 & 0 & 0 & 0 & 0 & 0 & 0 & 0 & 0 & 0 & 1 & 0 & 0 & 0 & 0 & 0 & 0 & 0 & 0 & 0 & 0 & 0 & 0 & 0 & 0 & 0 & 0 & 0 & 0 & 0 & 0 & 0 & 0 & 0 & 0 & 0 & 0 & 0 & 0 & 0 & 0 \\
\hline & & & & & & & & & & & & & & & & & & & & & & & & & & & & & & & & & & & & & & & & & & & & & & \\
\hline
\end{tabular}


Especificamente acerca dos 7 processos de apreensão em que a idade/período de vida foi indicada, encontrou-se os seguintes dados expressados pela tabela 11:

Tabela 11 - Relação de processos de apreensão em que a idade/período de vida foi indicada

\begin{tabular}{cc}
\hline Número e ano do processo & Dados encontrados \\
\hline 1. Processo 51 (1891) & 1 criança/jovem do sexo masculino com 5 anos \\
\hline 2. Processo 58 (1892) & 1 criança/jovem do sexo feminino, com 10 anos \\
\hline 3. Processo 61 (1894) & 1 criança/jovem do sexo masculino com 10 anos \\
\hline 4. Processo 77 (1898) & 1 criança/jovem do sexo masculino com 7 anos \\
\hline 5. Processo 79 (1899) & 3 crianças/jovens do sexo feminino com 13, 11 e 4 anos e 3 do \\
& sexo masculino com 15, 9 e 8 anos \\
\hline 6. Processo $80(1899)$ & 1 criança/jovem do sexo masculino com 12 anos \\
\hline 7. Processo $139(1910)$ & 1 criança/jovem do sexo feminino com 6 anos \\
\hline
\end{tabular}

Fonte: elaborada pela própria autora

Observa-se pela tabela 11 que crianças/jovens do sexo masculino foram os maiores alvos de processos de apreensão em que a idade/período de vida foi informada.

Especificamente acerca dos 15 processos de contrato de soldada em que a idade/período de vida foi indicada, encontrou-se os seguintes dados expressados pela tabela 12:

Tabela 92 - Relação de processos de contrato de soldada em que a idade/período de vida foi indicada

\begin{tabular}{|c|c|}
\hline Número e ano do processo & Dados encontrados \\
\hline 1. Processo 25 (1890) & 1 criança/jovem do sexo masculino com 9 anos \\
\hline 2. Processo $26(1890)$ & 1 criança/jovem do sexo masculino com 13 anos \\
\hline 3. Processo $33(1890)$ & 1 criança/jovem do sexo masculino com 10 anos \\
\hline 4. Processo 35 (1890) & 1 criança/jovem do sexo masculino com 4 anos \\
\hline 5. Processo $40(1890)$ & 1 criança/jovem do sexo masculino com 7 anos \\
\hline 6. Processo 41 (1890) & 1 criança/jovem do sexo masculino com 11 anos \\
\hline 7. Processo $42(1890)$ & 1 criança/jovem do sexo masculino com 12 anos \\
\hline 8. Processo $43(1890)$ & 1 criança/jovem do sexo masculino com 10 anos \\
\hline 9. Processo $44(1890)$ & 1 criança/jovem do sexo masculino com 9 anos \\
\hline 10. Processo 46 (1891) & 1 criança/jovem do sexo masculino com 10 anos \\
\hline 11. Processo 47 (1891) & $\begin{array}{c}1 \text { criança/jovem do sexo feminino com } 8 \text { anos e } 2 \text { do sexo } \\
\text { masculino com } 12 \text { e } 10 \text { anos }\end{array}$ \\
\hline 12. Processo 56 (1892) & 1 criança/jovem do sexo feminino com 8 anos \\
\hline 13. Processo 57 (1892) & 1 criança/jovem do sexo feminino com 12 anos \\
\hline
\end{tabular}




\begin{tabular}{cc}
\hline 14. Processo 81 (1899) & 1 criança/jovem do sexo feminino com 12 anos \\
\hline 15. Processo $88(1902)$ & 1 criança/jovem do sexo masculino com 14 anos \\
\hline
\end{tabular}

Fonte: elaborada pela própria autora

Observa-se pela tabela 12 que crianças/jovens do sexo masculino foram os maiores alvos de processos de contrato de soldada em que a idade/período de vida foi informada.

O único processo de prestação de contas de pessoa e bens em que a idade/período de vida foi indicada, encontrou-se como alvo uma criança/jovem do sexo masculino com 17 anos.

Especificamente acerca dos 4 processos de prestação de contas de soldada em que a idade/período de vida foi indicada, encontrou-se os seguintes dados expressados pela tabela 13:

Tabela 13 - Relação de processos de prestação de contas de soldada em que a idadelperíodo de vida foi indicada

\begin{tabular}{cc}
\hline Número e ano do processo & Dados encontrados \\
\hline 1. Processo $7(1888)$ & 2 crianças/jovens do sexo masculino com 16 e 13 anos \\
\hline 2. Processo 29 (1890) & 1 criança/jovem do sexo feminino com 1 anos \\
\hline 3. Processo 31 (1890) & 1 criança/jovem do sexo masculino com 15 anos \\
\hline 4 Processo 32 (1890) & 1 criança/jovem do sexo masculino com 14 anos \\
\hline
\end{tabular}

Fonte: elaborada pela própria autora

Observa-se pela tabela 13 que crianças/jovens do sexo masculino foram os maiores alvos de processos de prestação de contas de soldada em que a idade/período de vida foi informada.

Especificamente acerca dos 4 processos de remoção de tutor em que a idade/período de vida foi indicada, encontrou-se os seguintes dados expressados pela tabela 14:

Tabela 14 - Relação de processos de remoção de tutor em que a idade/período de vida foi indicada

\begin{tabular}{cc}
\hline Número e ano do processo & Dados encontrados \\
\hline 1. Processo 16 (1889) & 1 criança/jovem do sexo feminino com 6 anos e 1 do sexo \\
& masculino com 10 anos \\
\hline 2. Processo 55 (1892) & 1 criança/jovem do sexo masculino com 14 anos \\
\hline 3. Processo 72 (1896) & 1 criança/jovem do sexo masculino com 20 anos \\
\hline 4. Processo 140 (1911) & 1 criança/jovem do sexo feminino com 14 anos \\
\hline
\end{tabular}

Fonte: elaborada pela própria autora

Observa-se pela tabela 14 que crianças/jovens do sexo masculino foram os maiores alvos de processos de remoção de tutor em que a idade/período de vida foi informada. 
Especificamente acerca dos 4 processos de tutela ad hoc em que a idade/período de vida foi indicada, encontrou-se os seguintes dados expressados pela tabela 15:

Tabela 15 - Relação de processos de tutela ad hoc em que a idade/período de vida foi indicada

\begin{tabular}{cc}
\hline Número e ano do processo & \multicolumn{1}{c}{ Dados encontrados } \\
\hline 1. Processo 68 (1895) & 1 criança/jovem do sexo feminino com 14 anos \\
\hline 2. Processo 143 (1911) & 1 criança/jovem do sexo feminino com 18 anos \\
\hline 3. Processo 144 (1911) & 1 criança/jovem do sexo feminino com 18 anos \\
\hline 4. Processo 153 (1914) & 1 criança/jovem do sexo feminino com 16 anos \\
\hline
\end{tabular}

Fonte: elaborada pela própria autora

Observa-se pela tabela 15 que crianças/jovens do sexo feminino foram os maiores alvos de processos de tutela ad hoc em que a idade/período de vida foi informada.

Especificamente acerca dos 48 processos de tutela dativa em que a idade/período de vidada foi indicada, encontrou-se seguintes dados expressados pela tabela 16:

Tabela 16 - Relação de processos de tutela dativa em que a idadelperíodo de vida foi indicada

\begin{tabular}{|c|c|c|c|}
\hline $\begin{array}{l}\text { Número e ano do } \\
\text { processo }\end{array}$ & Dados encontrados & $\begin{array}{c}\text { Número e ano do } \\
\text { processo }\end{array}$ & Dados encontrados \\
\hline $\begin{array}{l}\text { 1. Processo } 1 \\
(1872)\end{array}$ & $\begin{array}{l}1 \text { criança/jovem do sexo masculino } \\
\text { com } 13 \text { anos }\end{array}$ & $\begin{array}{l}\text { 25. Processo } 108 \\
(1905)\end{array}$ & $\begin{array}{l}1 \text { criança/jovem do sexo masculino } \\
\text { com } 12 \text { anos }\end{array}$ \\
\hline $\begin{array}{l}\text { 2. Processo } 8 \\
(1888)\end{array}$ & $\begin{array}{l}1 \text { criança/jovem do sexo feminino } \\
\text { com } 10 \text { anos }\end{array}$ & $\begin{array}{l}\text { 26. Processo } 110 \\
(1906)\end{array}$ & $\begin{array}{l}1 \text { criança/jovem do sexo feminino } \\
\text { com } 12 \text { anos }\end{array}$ \\
\hline $\begin{array}{l}\text { 3. Processo } 11 \\
\quad(1889)\end{array}$ & $\begin{array}{c}1 \text { criança/jovem do sexo feminino } \\
\text { com } 9 \text { anos }\end{array}$ & $\begin{array}{l}\text { 27. Processo } 111 \\
(1906)\end{array}$ & $\begin{array}{c}1 \text { criança/jovem do sexo feminino } \\
\text { com } 8 \text { anos }\end{array}$ \\
\hline $\begin{array}{l}\text { 4. Processo } 20 \\
\text { (1889) }\end{array}$ & $\begin{array}{l}2 \text { crianças/jovens do sexo feminino } \\
\text { com } 8 \text { e } 7 \text { anos }\end{array}$ & $\begin{array}{l}\text { 28. Processo } 118 \\
(1906)\end{array}$ & $\begin{array}{l}1 \text { criança/jovem do sexo feminino } \\
\text { com } 2 \text { anos }\end{array}$ \\
\hline $\begin{array}{l}\text { 5. Processo } 23 \\
(1889)\end{array}$ & $\begin{array}{l}1 \text { criança/jovem do sexo feminino } \\
\text { com } 8 \text { anos }\end{array}$ & $\begin{array}{l}\text { 29. Processo } 123 \\
(1908)\end{array}$ & $\begin{array}{l}1 \text { criança/jovem do sexo feminino } \\
\text { com } 10 \text { anos }\end{array}$ \\
\hline $\begin{array}{l}\text { 6. Processo } 39 \\
(1890) \\
\end{array}$ & $\begin{array}{l}1 \text { criança/jovem do sexo masculino } \\
\text { com } 13 \text { anos } \\
\end{array}$ & $\begin{array}{c}\text { 30. Processo } 124 \\
(1908)\end{array}$ & $\begin{array}{l}1 \text { criança/jovem do sexo feminino } \\
\text { com } 10 \text { anos }\end{array}$ \\
\hline $\begin{array}{l}\text { 7. Processo } 49 \\
(1891)\end{array}$ & $\begin{array}{l}1 \text { criança/jovem do sexo feminino } \\
\text { com } 16 \text { anos }\end{array}$ & $\begin{array}{l}\text { 31. Processo } 127 \\
(1909)\end{array}$ & $\begin{array}{l}1 \text { criança/jovem do sexo feminino } \\
\text { com } 19 \text { anos }\end{array}$ \\
\hline $\begin{array}{l}\text { 8. Processo } 65 \\
\text { (1894) }\end{array}$ & $\begin{array}{l}1 \text { criança/jovem do sexo feminino } \\
\text { com } 10 \text { anos }\end{array}$ & $\begin{array}{l}\text { 32. Processo } 128 \\
\text { (1909) }\end{array}$ & $\begin{array}{l}1 \text { criança/jovem do sexo feminino } \\
\text { com } 2 \text { anos }\end{array}$ \\
\hline $\begin{array}{l}\text { 9. Processo } 66 \\
(1894) \\
\end{array}$ & $\begin{array}{l}2 \text { crianças/jovens do sexo feminino } \\
\text { com } 11 \text { e } 3 \text { anos }\end{array}$ & $\begin{array}{c}\text { 33. Processo } 132 \\
(1910)\end{array}$ & $\begin{array}{l}1 \text { criança/jovem do sexo feminino } \\
\text { com } 16 \text { anos }\end{array}$ \\
\hline $\begin{array}{l}\text { 10. Processo } 69 \\
(1895)\end{array}$ & $\begin{array}{c}1 \text { criança/jovem do sexo feminino } \\
\text { com } 9 \text { anos }\end{array}$ & $\begin{array}{l}\text { 34. Processo } 134 \\
(1910)\end{array}$ & $\begin{array}{l}1 \text { criança/jovem do sexo feminino } \\
\text { descrita como "recém-nascida" }\end{array}$ \\
\hline $\begin{array}{l}\text { 11. Processo } 71 \\
(1895)\end{array}$ & $\begin{array}{c}1 \text { criança/jovem do sexo feminino } \\
\text { com } 9 \text { anos e } 1 \text { do sexo masculino } \\
\text { com } 5 \text { anos }\end{array}$ & $\begin{array}{l}\text { 35. Processo } 135 \\
\text { (1910) }\end{array}$ & $\begin{array}{l}1 \text { criança/jovem do sexo feminino } \\
\text { com } 2 \text { anos }\end{array}$ \\
\hline $\begin{array}{l}\text { 12. Processo } 74 \\
(1896)\end{array}$ & $\begin{array}{l}2 \text { crianças/jovens do sexo masculino } \\
\text { com } 17 \text { e } 15 \text { anos }\end{array}$ & $\begin{array}{l}\text { 36. Processo } 136 \\
(1910)\end{array}$ & $\begin{array}{l}1 \text { criança/jovem do sexo feminino } \\
\text { com } 18 \text { anos }\end{array}$ \\
\hline $\begin{array}{l}\text { 13. Processo } 76 \\
(1898)\end{array}$ & $\begin{array}{l}1 \text { criança/jovem do sexo feminino } \\
\text { com } 6 \text { anos }\end{array}$ & $\begin{array}{l}\text { 37. Processo } 138 \\
(1910)\end{array}$ & $\begin{array}{l}1 \text { criança/jovem do sexo masculino } \\
\text { com } 12 \text { anos }\end{array}$ \\
\hline
\end{tabular}




\begin{tabular}{|c|c|c|c|}
\hline $\begin{array}{l}\text { 14. Processo } 82 \\
(1900)\end{array}$ & $\begin{array}{l}1 \text { criança/jovem do sexo feminino } \\
\text { descrita como "criança de mês" }\end{array}$ & $\begin{array}{l}\text { 38. Processo } 142 \\
\text { (1911) }\end{array}$ & $\begin{array}{c}2 \text { crianças/jovens do sexo feminino } \\
\text { com } 7 \text { e } 6 \text { anos e } 1 \text { do sexo } \\
\text { masculino com } 2 \text { anos }\end{array}$ \\
\hline $\begin{array}{l}\text { 15. Processo } 84 \\
(1901)\end{array}$ & $\begin{array}{c}3 \text { crianças/jovens do sexo feminino } \\
\text { com } 12,8 \text { e } 6 \text { anos e } 1 \text { do sexo } \\
\text { masculino com } 7 \text { anos }\end{array}$ & $\begin{array}{l}\text { 39. Processo } 145 \\
\text { (1911) }\end{array}$ & $\begin{array}{c}1 \text { criança/jovem do sexo feminino } \\
\text { com } 19 \text { anos }\end{array}$ \\
\hline $\begin{array}{l}\text { 16. Processo } 85 \\
\text { (1901) }\end{array}$ & $\begin{array}{l}1 \text { criança/jovem do sexo feminino } \\
\text { com } 13 \text { anos }\end{array}$ & $\begin{array}{l}\text { 40. Processo } 146 \\
\text { (1912) }\end{array}$ & $\begin{array}{c}1 \text { criança/jovem do sexo feminino } \\
\text { com } 11 \text { anos }\end{array}$ \\
\hline $\begin{array}{l}\text { 17. Processo } 89 \\
\text { (1902) }\end{array}$ & $\begin{array}{l}1 \text { criança/jovem do sexo masculino } \\
\text { com } 10 \text { anos }\end{array}$ & $\begin{array}{l}\text { 41. Processo } 148 \\
\text { (1912) }\end{array}$ & $\begin{array}{l}1 \text { criança/jovem do sexo masculino } \\
\text { com } 2 \text { anos }\end{array}$ \\
\hline $\begin{array}{l}\text { 18. Processo } 90 \\
(1902)\end{array}$ & $\begin{array}{l}1 \text { criança/jovem do sexo feminino } \\
\text { com } 18 \text { anos }\end{array}$ & $\begin{array}{l}\text { 42. Processo } 149 \\
(1913)\end{array}$ & $\begin{array}{l}1 \text { criança/jovem do sexo feminino } \\
\text { com } 11 \text { anos }\end{array}$ \\
\hline $\begin{array}{l}\text { 19. Processo } 91 \\
(1902)\end{array}$ & $\begin{array}{l}1 \text { criança/jovem do sexo masculino } \\
\text { com } 9 \text { anos }\end{array}$ & $\begin{array}{l}\text { 43. Processo } 150 \\
\text { (1913) }\end{array}$ & $\begin{array}{l}1 \text { criança/jovem do sexo masculino } \\
\text { com } 8 \text { anos }\end{array}$ \\
\hline $\begin{array}{l}\text { 20. Processo } 92 \\
(1903)\end{array}$ & $\begin{array}{l}1 \text { criança/jovem do sexo feminino e } \\
3 \text { do sexo masculino descritas como } \\
\text { "menos de } 12 \text { anos" }\end{array}$ & $\begin{array}{l}\text { 44. Processo } 151 \\
\text { (1913) }\end{array}$ & $\begin{array}{c}1 \text { criança/jovem do sexo feminino } \\
\text { com } 13 \text { anos }\end{array}$ \\
\hline $\begin{array}{l}\text { 21. Processo } 97 \\
(1903)\end{array}$ & $\begin{array}{l}1 \text { criança/jovem do sexo masculino } \\
\text { com } 3 \text { anos }\end{array}$ & $\begin{array}{l}\text { 45. Processo } 154 \\
\text { (1914) }\end{array}$ & $\begin{array}{l}1 \text { criança/jovem do sexo feminino } \\
\text { com } 16 \text { anos }\end{array}$ \\
\hline $\begin{array}{l}\text { 22. Processo } 99 \\
\text { (1904) }\end{array}$ & $\begin{array}{l}1 \text { criança/jovem do sexo feminino } \\
\text { com } 11 \text { anos }\end{array}$ & $\begin{array}{l}\text { 46. Processo } 162 \\
(1915)\end{array}$ & $\begin{array}{c}1 \text { criança/jovem do sexo masculino } \\
\text { com } 10 \text { anos }\end{array}$ \\
\hline $\begin{array}{l}\text { 23. Processo } 101 \\
(1905)\end{array}$ & $\begin{array}{l}1 \text { criança/jovem do sexo masculino } \\
\text { com } 14 \text { anos }\end{array}$ & $\begin{array}{l}\text { 47. Processo } 165 \\
\text { (1916) }\end{array}$ & $\begin{array}{l}1 \text { criança/jovem do sexo feminino } \\
\text { com } 17 \text { anos }\end{array}$ \\
\hline $\begin{array}{l}\text { 24. Processo } 104 \\
(1905)\end{array}$ & $\begin{array}{l}1 \text { criança/jovem do sexo feminino } \\
\text { com } 19 \text { anos }\end{array}$ & $\begin{array}{l}\text { 48. Processo } 168 \\
\text { (1917) }\end{array}$ & $\begin{array}{c}1 \text { criança/jovem do sexo masculino } \\
\text { com } 14 \text { anos }\end{array}$ \\
\hline
\end{tabular}

Fonte: elaborada pela própria autora

Observa-se pela tabela 16 que crianças/jovens do sexo feminino foram os maiores alvos de processos de tutela dativa em que a idade/período de vida foi informada.

Especificamente acerca dos 10 processos de tutela legítima em que a idade/período de vida foi indicada, encontrou-se seguintes dados expressados pela tabela 17:

Tabela 17 - Relação de processos de tutela legítima em que a idade/período de vida foi indicada

\begin{tabular}{cc}
\hline Número e ano do processo & Dados encontrados \\
\hline 1. Processo $4(1886)$ & 2 crianças/jovens do sexo masculino com 7 e 6 anos \\
\hline 2. Processo $45(1890)$ & 1 criança/jovem do sexo masculino com 10 anos \\
\hline 3. Processo 52 (1892) & 1 criança/jovem do sexo masculino com 4 anos \\
\hline 4. Processo $64(1894)$ & 1 criança/jovem do sexo masculino com 8 anos \\
\hline 5. Processo $83(1900)$ & 1 criança/jovem do sexo masculino com 10 anos \\
\hline 6. Processo 116 (1906) & 1 criança/jovem do sexo masculino com 4 anos \\
\hline 7. Processo 131 (1906) & 1 criança/jovem do sexo masculino com 3 anos \\
\hline 8. Processo 147 (1912) & 1 criança/jovem do sexo feminino com 19 anos \\
\hline 9. Processo 155 (1914) & 1 criança/jovem do sexo feminino com 17 anos \\
\hline 10. Processo 171 (1917) & 1 criança/jovem do sexo feminino com 12 anos \\
\hline
\end{tabular}

Fonte: elaborada pela própria autora 
Observa-se pela tabela 17 que crianças/jovens do sexo masculino foram os maiores alvos de processos de tutela legítima em que a idade/período de vida foi informada.

O único processo de remoção de tutor seguido de apreensão em que a idade/período de vida foi indicada, encontrou-se como alvos duas crianças/jovens do sexo feminino e uma do sexo masculino descritas como "impúberes". O único processo de remoção de tutor seguido de tutela dativa e prestação de contas de pessoa e bens em que a idade/período de vida foi indicada, encontrou-se como alvos duas crianças/jovens do sexo feminino com 10 anos e 14 anos. $\mathrm{O}$ único processo de remoção de tutor seguido de tutela legítima em que a idade/período de vida foi indicada, encontrou-se como alvo uma criança/jovem do sexo masculino com 3 anos. $\mathrm{O}$ único processo de tutela legítima seguido de apreensão em que a idade/período de vida foi indicada, encontrou-se como alvo uma criança/jovem do sexo masculino com 6 anos.

Buscou-se também saber se a cor da criança/jovem alvo no processo era indicada na descrição da mesma nas petições iniciais. Ao buscar tal informação, constatou-se que, por vezes, a cor da mãe e/ou do pai era indicada ao invés da criança/jovem. As cores que se referiam às crianças/jovens nos processos, quando citadas, são preta, parda, mulato claro e branca. Em relação a cor da mãe e/ou do pai, quando citadas nos processos, são preta, parda e mulata. Ao cruzar os dados coletados tendo a cor da criança/jovem como foco principal, obteve-se as seguintes informações expressadas pela tabela 18:

Tabela 18 - Processos em que a cor da criança/jovem foi indicada

\begin{tabular}{cccccc}
\hline $\begin{array}{c}\text { Cor da } \\
\text { criança/jovem }\end{array}$ & Tipo de ação & $\begin{array}{c}\text { Quantidade } \\
\text { de processos }\end{array}$ & Sexo & $\begin{array}{c}\text { Idade/período } \\
\text { de vida }\end{array}$ & $\begin{array}{c}\text { Cor da mãe } \\
\text { e/ou do pai }\end{array}$ \\
\hline Preta & $\begin{array}{c}\text { Contrato de } \\
\text { soldada }\end{array}$ & 1 & Feminino & Não consta & Não consta \\
Preta & Tutela dativa & 1 & Feminino & 10 anos & Não consta \\
Parda & Tutela dativa & 2 & $\begin{array}{c}\text { Feminino } \\
\text { (processos 1 e 2) }\end{array}$ & $\begin{array}{c}8 \text { anos } \\
\text { (processo 1) } \\
10 \text { anos } \\
\text { (processo 2) }\end{array}$ & $\begin{array}{c}\text { Não consta } \\
\text { (processo 1) } \\
\text { Mãe preta } \\
\text { (processo2) }\end{array}$ \\
Mulata clara & $\begin{array}{c}\text { Contrato de } \\
\text { soldada }\end{array}$ & 1 & Masculino & 10 anos & Mãe mulata \\
Branca & Tutela dativa & 1 & Feminino & 6 anos & Não consta \\
\hline
\end{tabular}

Fonte: elaborada pela própria autora

Ao cruzar os dados coletados tendo a cor da mãe e/ou do pai como foco principal, obteve-se as seguintes informações expressadas pela tabela 19: 
Tabela 19 - Processos em que a cor da mãe elou do pai foi indicada

\begin{tabular}{cccc}
\hline $\begin{array}{c}\text { Cor da mãe } \\
\text { e/ou do pai }\end{array}$ & Tipo de ação & $\begin{array}{c}\text { Quantidade } \\
\text { de processos }\end{array}$ & $\begin{array}{c}\text { Quantidade, sexo, cor e idade/período de vida de } \\
\text { crianças/jovens }\end{array}$ \\
\hline Mãe preta & Apreensão & 1 & 1 masculino \\
Mãe preta & $\begin{array}{c}\text { Contrato de } \\
\text { soldada }\end{array}$ & 4 & 1 masculino / 12 anos (processo 1$)$ \\
1 masculino (processo 2) \\
\end{tabular}

Fonte: elaborada pela própria autora

Observa-se pelas informações trazidas pelas tabelas 18 e 19 que a quantidade de processos em que a descrição da cor da criança/jovem, como de sua mãe e/ou pai são baixos, sendo que em 6 processos a cor da criança/jovem foi descrita, em 9 processos a cor da mãe foi descrita e em apenas 1 processo a cor do pai foi descrita. Ainda, é importante informar que em apenas 2 processos foram descritas a cor tanto da criança/jovem quanto da mãe (criança/jovem mulato claro com mãe mulata e criança/jovem parda com mãe preta). Pressupõe-se, ainda, que a não indicação de cor da criança/jovem no processo seria pelo fato desta ser branca, uma vez que esta seria vista como a cor "padrão" e esperada da sociedade brasileira que estava se constituindo (BRIOSCHI, 1995).

Buscou-se observar também a produção dos processos utilizados como fonte para a pesquisa em relação a duas leis abolicionistas ocorridas no período pesquisado, a Lei Rio Branco, mais conhecida com a Lei do Ventre Livre, em 28 de setembro de 1871 (BRASIL, 1871), e a Lei $n^{o}$. 3.353, de 13 de maio de 1888, mais conhecida como Lei Áurea (BRASIL, 1888). Considerando o recorte temporal da pesquisa, todos os processos selecionados para fins de estudo foram produzidos após a Lei do Ventre Livre, uma vez que o primeiro processo selecionado encontrado no APHRP consta com a data de 1872. Contudo, é relevante notar algumas implicações do cenário pós-Ventre Livre com a produção judicial em Ribeirão Preto. 
Conforme já discutido anteriormente acerca da Lei do Ventre Livre, ainda que não considerada mais como propriedade dos senhores de sua mãe e/ou pai, a criança nascida em ventre escravo deveria ficar sob os cuidados deste senhor até que completasse 8 anos de idade, sendo que este deveria arcar com seus cuidados, incluindo sua educação. Posteriormente a esta idade, o senhor poderia libertar a criança ao receber uma indenização do governo ou, então, permanecer com a mesma até que esta completasse 21 anos de idade, usufruindo de seus serviços ao tutelá-la/contratá-la. Isto posto, nota-se que o número de processos de contrato de soldada encontrados no APHRP são 20, considerando também a adição dos 8 processos de prestação de contas de soldada - o que pressupunha um outro processo anteriormente aberto para a contratação em si.

Em relação a produção judicial do corpus documental selecionado para a pesquisa em Ribeirão Preto que foi encontrada no APHRP diante do cenário pré-abolição, obteve-se as seguintes informações expressadas pela tabela 20:

Tabela 20 - Quantidade de processos encontrados no APHRP no período pré-abolição

\begin{tabular}{ccc}
\hline & \multicolumn{2}{c}{$\begin{array}{c}\text { Produção judicial pré-abolição } \\
\text { (data da petição inicial até 13 de maio de 1888) }\end{array}$} \\
\hline $\begin{array}{c}\text { Data da petição } \\
\text { inicial }\end{array}$ & $\begin{array}{c}\text { Descrição original de } \\
\text { ação }\end{array}$ & $\begin{array}{c}\text { Tipo de ação } \\
\text { (categorizada após a leitura da petição inicial) }\end{array}$ \\
$01 / 03 / 1872$ & Tutella & Tutela dativa \\
$03 / 11 / 1874$ & Requisição de orphão & Contrato de soldada \\
$13 / 03 / 1876$ & Remoção de tutela & Remoção de tutor + Tutela dativa \\
$13 / 11 / 1886$ & Tutella & Tutela legítima \\
$28 / 12 / 1886$ & Tutella & Tutela dativa \\
\hline
\end{tabular}

Fonte: elaborada pela própria autora

É necessário notar que anteriormente à abolição da escravidão no Brasil, na amostra de processos que foi apresentada, há poucos exemplares relativos à tutela e/ou contratação de soldada, o que, de certa forma, pressupõe-se condizer com uma dita lógica espontânea da época pesquisada acerca da condição de escravidão, no que se refere em usufruir do trabalho e da vida do outro (FLORENTINO, 2003), uma vez que a historiografia da temática trabalhada explica que as tutelas, especialmente as dativas, poderiam ser utilizadas para compor a mão-de-obra doméstica na casa do próprio tutor. Assim, entende-se que a não regularização dos serviços prestados pelas crianças/jovens, por exemplo, especialmente as indicadas como órfãos, menores, de camadas mais baixas (não possuindo bens) e até mesmos as poucas de cor negra 
indicadas nos processos, não se tornaria alvo de jurisdição de acordo com a estigma de tais condições sociais e raciais. Dos 171 processos selecionados para a pesquisa, apenas os 5 informados pela tabela 20 foram produzidos antes da Lei Áurea (BRASIL, 1888), sendo estes, em sua maioria, envolvendo algum tipo da prática de tutela.

De acordo com os dados coletados, o instituto jurídico ribeirão-pretano teve como principal alvo de ações crianças/jovens do sexo masculino para serem tutelados por terceiros. Tomando como referências as poucas informações acerca das idades coletadas, observa-se que crianças/jovens entre 6 e 17 anos foram requeridas de alguma forma. Ainda, e mesmo considerando a baixíssima coleta de dados acerca da cor dessas crianças/jovens e suas mães e/ou pais, pode-se pressupor que a população infanto-juvenil negra e masculina foi alvo do judiciário ribeirão-pretano. Considera-se também que a falta de certos dados, como idades e cor das crianças/jovens, seja um novo dado para se pensar sobre o tratamento destas pelo judiciário, seja pelo possível silenciamento dos sujeitos ali encontrados, tanto pela própria organização da instituição jurídica no tratamento de tais informações, considerando as condições objetivas e subjetivas de produção e desenvolvimento dos processos. Com isso, é possível pressupor pelos números elucidados que o judiciário local, de alguma forma, influenciou no controle da infância, principalmente a desvalida, em Ribeirão Preto. 


\section{DO ABANDONO À ASSISTÊNCIA DA INFÂNCIA DESVALIDA: HISTORIOGRAFIA E LEGISLAÇÃO}

\subsection{Contextualização sociohistórica das práticas do abandono de crianças e assistência da infância desvalida no Ocidente}

Com vistas a melhor compreender e fundamentar o caso específico de Ribeirão Preto no que se refere às práticas de tutela e soldada ocorridas no período pesquisado, entende-se a importância em se realizar uma contextualização sociohistórica acerca das práticas de abandono e assistência da infância desvalida não apenas na região, mas desde seu estabelecimento em Portugal e as intervenções ocorridas no território brasileiro desde o período colonial. Optou-se realizar tal fundamentação pelo estudo desenvolvido por Luiza Maria Marcílio (1998), considerando sua extensa colaboração para área de pesquisa e o período histórico selecionado, uma vez que seu estudo específico acerca das práticas de abandono e assistência continua sendo conceituado como pioneiro e pleno.

Em História Social da Criança Abandonada, Marcílio (1998) busca explicar e analisar as motivações para o abandono de crianças ao longo da história, tomando como base as práticas ocorridas no Ocidente, especificamente no Brasil. A autora explica que tal fenômeno encontrase relacionado aos modos de proteção e assistência às crianças, as quais têm sido construídas no decorrer da história no Ocidente, iniciando-se desde o momento denominado Velho Mundo e sendo reproduzidas no país desde o período da colonização por Portugal (MARCÍLIO, 1998). De acordo com a autora:

O ato de expor os filhos foi introduzido no Brasil pelo branco europeu [...]. Aí está outro dos lados perversos da colonização. Como consequência, o português introduziu leis, instituições e comportamentos de assistência e de proteção à infância abandonada, nos moldes do que havia adotado desde tempos medievais. Tanto as leis como os moldes de instituições de abrigo e de proteção à infância sem-família, foram forjados na longa duração da História da Europa. (MARCÍLIO, 1998, p. 12).

Assim, torna-se necessário compreender que o modelo de assistência e proteção à infância desenvolvido no Brasil tomou forma a partir de experiências externas, tendo sido devidamente instalado na colônia através do regimento português, o qual adotara modelos de outras partes da Europa, como Itália e França, países os quais são considerados como precursores no que se refere sobre meios de assistência à infância, especificamente a abandonada e sem família, no chamado Antigo Regime europeu do século XIX (MARCÍLIO, 1998). 
Acerca do costume de abandono e adoção de crianças, Marcílio (1998) elucida sobre possíveis associações de tal fenômeno com fontes bíblicas, mitologia e filosofia grega e romana. Passagens do Antigo Testamento indicavam alusões tanto ao abandono quanto a adoção de infantes, a exemplo de Ismael, filho de Abraão com uma de suas escravas o qual fora abandonado pelo pai a pedido de sua esposa Sara, e Moisés, abandonado às margens do Rio Nilo e adotado pela filha do Faraó e, mais tarde, tornando-se importante para a história de libertação do povo hebreu. Ainda, também é possível encontrar passagens as quais verifica-se o costume aceito por lei do pai vender seus filhos e reavê-los se assim desejasse. Entre a mitologia grega, era recorrente o caso de crianças enjeitadas, a exemplo de Épido, abandonado por seu pai quando este fora informado que seu próprio filho o mataria. Já entre os filósofos, tal tema também fora debatido, ainda que de modo sucinto, a exemplo de Platão, que sugerira que os pais não deveriam ter mais filhos do que pudessem criar, realizando uma possível alusão ao abandono, assim como Aristóteles, o qual discutira acerca da limitação de prole e considerando o abandono de filhos como meio de controle social. Em termos de adoção, a Grécia Clássica teria estabelecido alguns princípios para adoção de crianças por casais os quais não teriam filhos. No Império Romano, o abandono de crianças também não fora um fenômeno raro, sendo até realizado em lugares já estabelecidos pelos habitantes, sendo que fora em Roma regularizado pela primeira vez o direito a adoção, estabelecendo normas básicas para a realização de tal costume (MARCÍLIO, 1998). Isto posto, é importante atentar-se que o costume do abandono e da adoção se desenvolvera de acordo com a passagem dos séculos e com as mais variadas expressões de culturas e valores no ocidente.

Ainda que não seja a finalidade deste trabalho analisar a influência religiosa, principalmente no que tange as iniciativas da igreja católica quanto a assistência à infância desvalida, é de suma importância realizar alguns esclarecimentos acerca de tais iniciativas e como influenciaram o cenário brasileiro a fim de pavimentar a análise específica do caso de Ribeirão Preto. Ademais, tal importância também se une ao fato de que o Brasil, desde os primórdios de sua tomada pelos portugueses, iniciada no período de colonização, fora demasiadamente influenciado tanto pelo regime da coroa portuguesa como pelo o que ditava a igreja através das missões jesuíticas no país, ocorridas do ano de 1549 até a expulsões dos jesuítas no século XVIII.

Conforme explicado brevemente, Marcílio (1998) comenta sobre as possíveis alusões ao abandono de infantes no Velho Testamento, mas que também "as tradições judaicas e romanas a respeito do abandono de crianças e dos cuidados com crianças desemparadas foram passadas para os primeiros cristãos romanos" (MARCÍLIO, 1998, p. 27). Mesmo com a difusão 
do cristianismo no Império Romano, as práticas de abandono possíveis de serem incitadas em Êxodo (21:8), Gênese (37) e Reis (4:1) eram debatidas pelos moralistas da igreja na época, uma vez que estes "não condenavam o ato dos pais de abandonar seus filhos, mas sim os possíveis resultados que disso poderiam decorrer: incestos, infanticídio, estímulo a relações extramatrimoniais ou à prostituição" (MARCÍLIO, 1998, p. 27). Contudo, é no início do século IV que o discurso da igreja quanto ao amparo das crianças abandonadas torna-se mais rígido, estabelecendo uma postura realista sobre o problema em questão: ainda que o abandono não fosse a melhor das opções, fiéis eram encorajados a não praticarem o aborto e infanticídio, sendo que, talvez, o abandono se tornaria justificável. Visto tal problema, a igreja passou a estabelecer mais fortemente princípios caritativos quanto aos enjeitados, sendo que "a partir do século $\mathrm{V}$, houve estímulo à aliena misericordia (a misericórdia do outro) de modo explícito ou implícito e em escala sem precedentes, em toda a Europa" (MARCÍLIO, 1998, p. 29), como também que "o apelo constante ao dever de dar esmolas demonstra que a Igreja fez da caridade uma condição para a salvação" (MARCÍLIO, 1998, p. 30).

Sobre os séculos VI e VII, observa-se que o debate sobre a sexualidade estava em pauta, ainda que de modo não escancarado - considerando-se o tabu de viés religioso acerca de tal questão -, realizando-se associações da proibida utilização de métodos contraceptivos com a prática do abandono:

Muitos homens e mulheres da época abandonavam seus filhos por questões morais e
econômicas. Os legisladores civis e religiosos tentaram reprimir não apenas os
métodos contraceptivos, mas também o aborto, o infanticídio e o abandono de bebês.
Os métodos contraceptivos - herdados da Antiguidade - foram denunciados, pelos
predicadores, pelos penitenciais e pelos legisladores canônicos como práticas
mágicas. O infanticídio - considerado o mal mais grave - é denunciado em todos os
textos. Já o abandono de bebês era considerado um mal menor: procurava-se somente
limitá-lo. Os mosteiros constituíram um refúgio para muitas dessas crianças. Neles,
os pequenos abandonados encontravam com que se vestir, se alimentar, se educar e o
mais importante, meios de salvação - como se acreditava - para si e para suas famílias.
(MARCíLIO, 1998, p. 34).

Além de mosteiros que acolhiam crianças abandonadas, Marcílio (1998) explica acerca do surgimento da oblata, instituição voltada para que pais ofertassem seus filhos à ordem religiosa como meio de não praticar o abandono de crianças com até 10 anos de idade. Ao ser acolhida por tal instituição, a criança perderia sua liberdade individual, igualando-se às crianças abandonadas que foram criadas como escravas, mas ainda de modo mais restritivo, uma vez que aquelas "podiam manter relações sexuais, ter esperança de [...] recuperar o status de livres ou, ainda, receber a liberdade de senhores benevolentes" (MARCÍLIO, 1998, p. 36). Assim, ao ser ofertada à oblata, a criança estaria destinada "a uma vida de pobreza, obediência e castidade, 
para sempre" (MARCÍLIO, 1998, p. 36), mas considerando-se que "a oblata era a mais humana forma de abandono existente" (MARCÍLIO, 1998, p. 36). Ainda, hospitais monásticos foram criados e orientados no oferecimento das mais variadas formas de assistência aos miseráveis, como crianças abandonadas, abrigo aos peregrinos e andarilhos, além de serviços de enfermagem, originando-se no Ocidente cristão na Idade Média, sendo que:

A partir do século XIII, o hospital medieval começa a sair das mãos dos religiosos e passa à jurisdição secular. Os municípios assumem a responsabilidade pelos doentes, pobres e desvalidos. É claro que não houve uma total substituição do clero nesse setor. As duas formas de assistência conviveram por tempo ainda. (MARCÍlLIO, 1998, p. 39).

Assim, pressupõe-se que se fundamentava o encaminhamento da assistência à infância desvalida influenciada pela igreja como de responsabilidade jurídica das civilizações e seus governantes.

Contudo, observa-se que é no século XII em que a igreja assume, de fato, o controle de instituições voltadas para a prática de assistência aos pobres, uma vez que ao acompanhar o crescimento de sujeitos em situações de miserabilidade, o discurso acerca do auxílio aos que se encontravam em condições de pobreza ganhava cada vez mais força, principalmente por tal auxílio ser constantemente associado a uma virtude louvável. Contudo, a relação com a pobreza se apresentava de modo paradoxal, uma vez que "ela pode ser útil ao rico, como meio de salvação, quanto ao pobre, como meio de santificação" (MARCÍLIO, 1998, p. 42), podendo se considerar tal relação como o prenúncio das novas formas de assistência à infância desvalida que começaram a aparecer, como também as transformações internas que a própria igreja estivera sofrendo, uniformizando e universalizando suas normas.

No século XIII, novas regulamentações acerca do matrimônio (definindo os graus de parentesco aceitos para contrair casamento) e compadrio influenciaram na prática de adoção e como tais deveriam ser realizados, pressupondo a diminuição do abandono de crianças. Assim, a igreja Ocidental teria tentado extinguir a prática de adoção de crianças por outras famílias uma vez que estas teriam direito à herança - e tentado tornar o costume de apadrinhamento sendo este ato comparado a uma adoção diante Deus - como meio de lidar com os possíveis abandonos persistentes. Contudo, Marcílio (1998) possivelmente desvenda a real intenção de tais ações, uma vez que "o desaparecimento da adoção do sistema social europeu deve ser explicado com base no sistema de herança montado no Ocidente medieval. A tendência foi a de legar os bens, sem herdeiros naturais, para fins de caridade, de obras pias" (MARCÍLIO, 1998, p. 46), sendo tais obras gerenciadas pela igreja. De certa forma, neste período houve uma 
ligeira diminuição no ato de abandonar crianças, mas isso não significou que tal ação fora extinguida por completo.

Um fator interessante é o de notar possíveis indícios de formulações das práticas de tutela e contratação de soldada nos séculos XII e XIII, quando "os pobres colocavam seus filhos como aprendizes de um ofício ou davam-nos a criar [...]. [...] o medo de represálias, da Inquisição, de incorrerem em pecado, ou do fogo do inferno deve ter obrigado os pobres a não expor seus filhos" (MARCÍLIO, 1998, p. 47).

A reorganização das formas de assistência fez com que tal prática, ao ser assumida pelos governos locais em conjunto a igreja, levasse ao surgimento de uma nova fase denominada por Marcílio (1998) como de caridade pública e proteção à infância desvalida, na qual ocorrera o aparecimento da primeira Roda de Expostos em Roma, no século XII e também instituições que não apenas acolhessem os enjeitados, mas que procuravam realizar atividades para o aproveitamento desses sujeitos no futuro - também podendo ser outro indício para a regularização do contrato de soldada:

São Basílio e São Pacômio, ao fazerem as regras dos mosteiros do Oriente [cristão], inscreveram nelas, dentre muitos conselhos, o de criar as crianças desvalidas desde pequeninas, ensinando-lhes uma profissão conforme as aptidões de cada uma. Teve início, assim, a prática de capacitação da criança pobre para o mundo do trabalho. (MARCÍLIO, 1998, p. 50, grifo nosso).

Especificamente sobre a Roda dos Expostos, tal local fora elaborado para que crianças destinadas ao abandono fossem abrigadas por alguma instituição religiosa, tendo como finalidade o combate ao infanticídio, muitas das vezes motivados pelo fato desta ter sido concebida através de uma relação ilegítima ou então até mesmo de uma relação legítima na qual os pais encontravam-se em extrema pobreza e sem condições de alimentar mais uma boca. Uma vez deixada na Roda, a criança era batizada em busca da salvação de sua alma e alimentada por uma ama de leite. Na instituição, procurava-se meios de encaminhar os enjeitados, sendo que “[...] os meninos eram iniciados desde cedo em um ofício, enquanto as meninas eram encaminhadas, bem jovens, ao casamento dando-se a cada uma delas, quando possível, um modesto dote" (MARCÍLIO, 1998, p. 57), mas também "ocasionalmente, as crianças expostas eram 'adotadas' por famílias que, muitas vezes, viam nelas uma complementação para a mão de obra familiar" (MARCÍLIO, 1998, p. 57). Assim, observa-se que ainda que houvessem reais intenções no que se refere em realizar uma assistência à infância abandonada, procurando salvála de algum destino trágico, por vezes, entendia-se que uma possível remediação da situação se encontrava ao designar um futuro proveitoso para a criança pobre, introduzindo-a ao mundo do trabalho desde a tenra idade. Ademais, no mesmo período, o conceito de "ser pobre" passa por 
mudanças na mentalidade da população, principalmente a mais abastada. Antes digno de atenção e compaixão, o pobre passa a ser associado com a vagabundagem, uma vez que "a pobreza é condenada pelos humanistas, como indigna do ser humano. [...] ela é uma decadência resultante do pecado, e a mendicidade uma infração à lei do trabalho. [...] Convém, pois, esconder a primeira e reprimir a segunda" (MARCÍLIO, 1998, p. 60).

Com o aumento da população nas cidades gerando, consequentemente, o agravamento da condição de miséria de muitos, e a mudança na mentalidade sobre o "ser pobre" - saindo da condição de uma possível falta de sorte e sendo considerado como escolha associada à vagabundagem -, o Estado passa a se tornar mais efetivo no que se refere em participar de ações que pudesse atenuar a miserabilidade e melhorar a assistência. Assim, "a filantropia passou a ser um dos elementos essenciais das monarquias esclarecidas - passaram a entender que o Estado deveria ser co-responsável pela assistência aos necessitados” (MARCÍLIO, 1998, p. 62). Ainda, sobre a filantropia, esta perspectiva passa a ser assumida especificamente no combate à mortalidade infantil. Mesmo que ainda se procurasse realizar intervenções de modo assistencialista, observa-se que a classe médica da época inicia em toda a Europa ações de modo a orientar nos cuidados com as crianças, principalmente bebês abandonados. Uma reorganização do modelo de auxílio aos enjeitados toma forma e é iniciada no século XIX uma política voltada para diminuir a mortalidade dos infantes, passando do campo moral e religioso para um problema específico de questões sociais da época (MARCÍLIO, 1998).

Ainda, tem-se início a fase denominada por Marcílio (1998) como de filantropia nos séculos XVIII, XIX e parte do XX. É neste momento em que se observa grandes críticas às prerrogativas da igreja quanto a assistência à infância pobre, passando do campo da caridade religiosa para a necessidade de uma beneficência pública, acompanhando as mudanças ideológicas trazidas pelo liberalismo no período. Acerca do termo "filantropia", a autora o toma como ambíguo, uma vez que em sua utilização genérica, este designa "o conjunto das obras sociais, caritativas e humanitárias de iniciativa privada, quer sejam confessionais, ou não" (MARCÍLIO, 1998, p. 73), mas, se voltado especificamente ao período comentado, "são chamadas filantrópicas - em oposição às fundações religiosas - as obras pluralistas, as obras neutras ou interconfessionais, sem finalidade missionária” (MARCÍLIO, 1998, p. 73).

Partindo de uma perspectiva produtiva e utilitarista, o exposto passa a ser visto como devedor da sociedade que o acolhe, pertencendo ao Estado e sendo incentivado ao aprendizado profissional, ao serviço da pátria e até mesmo a conquista e permanência de territórios (MARCÍLIO, 1998, p. 72): 
O utilitarismo do século XVIII vê com horror a alta mortalidade dos expostos: são cidadãos úteis que a pátria não deveria perder. Eles poderiam servir nos exércitos ou trabalhar em serviços pesados; ou poderiam ser embarcados para as colônias que a Europa conquistara na América, na África, na Ásia (especialmente para as regiões de vida mais difícil e inóspita). Os expostos poderiam também ajudar a povoar muitas dessas colônias, com ótimos resultados para a nação dominante. Aos olhos dos contemporâneos os expostos eram devedores da sociedade, marcados pela origem de seu nascimento.

Ainda que se buscasse tratar o problema da infância desvalida a partir de ações consideradas mais inovadoras do que as incitadas pela sociedade religiosa, observa-se que, possivelmente, estas partiam de uma (óbvia) relação entre a família patriarcal e o Estado paternalista Ocidental. Especificamente no caso dos hospitais de expostos e os hospícios, sendo estes utilizados como local de "passagem" de possíveis enjeitados para seu batismo e alimentação realizada por amas de leites, a função primordial de tais locais era "a de garantir a honra da mãe e a salvação a alma da criança” (MARCÍLIO, 1998, p. 73).

Entre os fins o século XVIII e início do século XIX, a caridade passa a ser entendida e disseminada como uma inclinação da natureza humana e não apenas de cunho religioso ou daqueles que vivem de acordo com os preceitos do catolicismo. Ainda, observa-se a intervenção da classe média burguesa pela organização da sociedade com a "busca obstinada da ordem, da eficiência e da disciplina social; e a preocupação com a condição humana. É nesse contexto que se inscreve o movimento do bem-estar da criança" (MARCÍLIO, 1998, p. 75) e, considerando que "a filantropia é filha do Iluminismo, do Higienismo e da Revolução Industrial" (MARCÍLIO, 1998, p. 75), esta passa a compartilhar com os princípios da caridade a melhoria da situação de pobreza pelo controle social devido ao aumento demográfico da população. Marcílio (1998, p. 75) constata que "o século XIX foi [...] o século da criança na Europa. Da criança legítima, ilegítima e da abandonada", sendo com a filantropia o início de possíveis formulações para a proteção à infância.

Outra medida tomada para combater o abandono de infantes iniciada no século XIX foram as alocações familiares ou meios de assistência às mães pobres, sendo que o primeiro também pode ter contribuído para o gerenciamento da prática de tutela que estava tomando forma (MARCÍLIO, 1998). Inclusive, a área médica vinha contribuindo de forma significativa para essa assistência, sugerindo cuidados de higiene no período de amamentação, principalmente os realizados por amas de leites que cuidavam de expostos abandonados nas Rodas, como também ressignificando as funções e os tipos de pessoas a serem atendidas pelos de hospitais da época:

Aos poucos os hospitais foram deixando de ser um depósito de doentes pobres, passando a receber a classe média e, logo depois, a própria elite, que começou a 
frequentá-los para se tratar. Com isso, iam sendo fechados os Hospitais de Expostos, com seu caráter de abrigo para os pequenos enjeitados. Novas formas de proteção à infância desvalida foram sendo desenvolvidas, estudadas e planejadas pela filantropia higiênica, sob forma de asilos, colônias, orfanatos, colégios, creches etc.

[Ainda] A luta dos higienistas pela conservação da vida das crianças levou ao desenvolvimento da Puericultura (1863) e da Pediatria (1872). (MARCÍLIO, 1998, p. 84).

Com o fechamento das Rodas, com a tomada dos hospitais pela elite, com as intervenções da classe médica da época e com a perspectiva de pertencimento dos expostos pelo Estado, observa-se significativas mudanças quanto a remediação da prática do abandono de crianças no final do século XIX. Explica Marcílio (1998) que ao não se respeitarem as novas normas de cunho educativo e médico com a adição da comprovada situação de pobreza das famílias, sendo esta associada de modo crescente à imoralidade, "a suspensão do pátrio poder permitia o estabelecimento de um processo de tutela, que aliava os objetivos sanitários e educativos aos métodos de vigilância econômica e moral" (MARCÍLIO, 1998, p. 85). Assim, o favorecimento da perda de autonomia pelas famílias quanto aos cuidados e educação de suas crianças auxiliou no estabelecimento de intervenções jurídicas.

\subsubsection{Das práticas de abandono e regularização da assistência lusas à possível gênese da assistência à infância desvalida no Brasil}

A história do abandono de crianças, assim como os moldes de assistência em Portugal, se assemelha às condições e motivações ocorridas durante a formação de outros territórios europeus. Explica Marcílio (1998) que, possivelmente, desde o século X, a existência de instituições que assistiam aos miseráveis de modo caritativo já ocupavam parte do território português na forma de hospitais, sendo estes mantidos com o apoio de entidades religiosas, doações e/ou legados deixados pelos governantes preocupados em sanar o problema. Ainda, fora desenvolvida a forma de acolhimento de crianças consideradas "perdidas" por ermitãos e ermitãs - indivíduos que, usualmente, encontravam-se em penitência religiosa e/ou em busca de um modo de vida austero - que encaminhavam estas para os hospitais de expostos ou então às autoridades locais, cumprindo seu dever cristão. Assim:

As primeiras instituições de assistência direta à criança abandonada foram criadas a partir dos esforços conjugados da sociedade e da coroa, no momento em que surgiam as confrarias de caridade e as corporações de ofício. Seguia-se aqui o mesmo movimento verificado na Europa feudal. A ação decisiva partia, frequentemente, das mulheres da nobreza, das infantas e das Rainhas. (MARCÍlLIO, 1998, p. 90). 
Observa-se, especificamente no caso de Portugal, que muitas das primeiras iniciativas quanto a assistência da infância abandonada incluíam, além dos preceitos religiosos, como o batismo para a salvação da alma, uma possível preocupação quanto ao aprendizado de algum ofício pelos meninos, como no caso averiguado no hospital de Santarém (MARCÍLIO, 1998). Contudo, a ação mais prolongada que se mantinha ligada com ações de proteção à infância em Portugal fora a Confraria da Misericórdia, sendo esta sido criada seguindo a inclinação europeia quanto às práticas de assistência voltadas para crianças abandonadas. Contudo, mesmo que "em seu compromisso [...], renovado em 1516, a Misericórdia não incluía o amparo aos expostos" (MARCÍLIO, 1998, p. 92), desde seu princípio, a Confraria da Misericórdia lisboeta "nunca deixou de assisti-los, de forma sistemática e institucionalizada” (MARCÍLIO, 1998, p. 92). Ainda, é profícuo informar que a coroa portuguesa nunca chegou a assumir a responsabilidade definitiva dos estabelecimentos de assistência aos enjeitados, mas permaneceu monitorizando as decisões tomadas e contribuindo, às vezes, ao contribuir com algum tipo de subsídio financeiro.

Com o surgimento dos municípios em Portugal, o gerenciamento das práticas de assistência aos expostos fora entregue às Câmaras Municipais, sendo tal determinação respalda pelas Ordenações do Reino, renovadas pelo Código Filipino promulgado em 1603 (MARCÍLIO, 1998). Ainda, “os alvarás régios de 22/8/1654 e de 22/12/1656 reconfirmaram a obrigatoriedade de as Câmaras exercerem essas funções" (MARCÍLIO, 1998, p. 94), sendo o dever destas apurarem se haviam recursos disponíveis necessários para a manutenção da assistência. Contudo, se os recursos fossem insuficientes, estas "poderiam criar um imposto extraordinário, chamado de 'Finta dos Enjeitados', para subsidiar as despesas com as crianças” (MARCÍLIO, 1998, p. 94), tendo sido utilizada por várias municipalidades portuguesas.

Observa-se, também, o encaminhamento dos enjeitados às práticas de tutela e de soldada, como também a solicitação das crianças pelos pais que as abandonaram, o pedido de tutela das crianças por amos e/ou amas que as criaram, tendo a intervenção jurídica na regularização e registros:

Um valioso depoimento nos dá conta de como o Hospital de Todos os Santos criava os expostos: 'Esta casa recolhe os enjeitados que se acham à porta do hospital e na Misericórdia e por toda a cidade e são recolhidos por duas amas que há no hospital que os levam à casa da fazenda perante o Ouvidor e mais oficiais que as lançam em livro". Todos os anos, na véspera do dia de Todos os Santos, o hospital fazia vir as amas dos expostos com as crianças que cuidavam, "aos quais dão de comer abastadamente e lhe pagam o que assim é devido de sua criação...” Nessa ocasião, os meninos maiores "são dados ao ofício que cada um quer, e as moças dão de obrigação de casamento e não casando que seja obrigado o que toma a lhe dar quanto se dá a um órfão de soldada". Tudo devidamente registrado. Muitas vezes, o pai do enjeitado "pede ao provedor que lhe entregue; e é-lhe entregue, jurando que é seu 
filho; e se quer dar alguma coisa para a casa pela criação que até aí lhe foi feita, dá o que quer, e não lhe deixam entregar, ainda que não dê nada. Também nesse dia ocorre que os amos e amas desses enjeitados os pedem e os perfilham... e... para isso se faz escritura pública e registro'. (MARCÍLIO, 1998, p. 95, grifo nosso).

Outrossim, além de medidas de encaminhamento das crianças abandonadas, as meninas foram os maiores alvos de preocupação quanto aos seus futuros, uma vez que se acreditava que qualquer descuido na assistência destas poderia induzi-las para os vícios de uma vida ociosa e à prostituição. Assim, era recomendado que estas fossem enviadas para famílias de boas virtudes para que mantivessem sua honra de acordo com a decorosa doutrina religiosa vigente. Já os meninos "saiam aos oito, dez ou doze anos da Casa de Expostos de Lisboa, e eram emancipados aos vinte anos" (MARCÍLIO, 1998, p. 112), demonstrando assim que estes, desde muito cedo e ainda que na condição de enjeitados, tinham mais autonomia acerca de seu futuro do que as meninas. Ainda, observava-se uma mudança para o encaminhamento das crianças, as quais foram sofrendo cada vez mais intervenções do campo jurídico:

Aos sete anos, as crianças retornavam à Casa da Roda [após permanecerem com suas
nutrizes]. Se a ama não ficasse com o exposto depois do sétimo aniversário, ele
esperaria na Casa da Roda alguém que o quisesse levar. A criança passava então
para a alçada do Juiz de Órfãos, que procurava colocá-la em casas de família ou
a tornava 'assoldada'. As casas de família das grandes cidades portuguesas
abasteciam-se de mão-de-obra gratuita, ou quase, para os serviços domésticos, nas
Rodas de Expostos. Daí advém a vulgarização do termo criada, para designar as
expostas criadas em casas de família, prestando, em troca, serviços domésticos.
(MARCÍLIO, 1998, p. 112, grifo nosso).

O caso das nutrizes portuguesas é digno de atenção, visto muitas medidas estabelecidas para a manutenção da função de ama exercida pelas mulheres. A coroa portuguesa estimulava tal prática pelo estabelecimento de prêmios para aquelas amas que criassem expostos de modo gratuito, acrescentado a isenção do serviço militar pelos maridos e filhos homens destas. Também, estas passaram a ser selecionadas segundo orientações de médicos higienistas, pois "não bastava que as amas-de-leite fossem saudáveis e limpas: era de fundamental importância que se atentasse para suas qualidades morais” (MARCÍLIO, 1998, p. 110). Ainda, sugira no século XIX na forma de alvará uma regulamentação voltada às mulheres para combater a prática do abandono. O alvará datado de 18 de outubro de 1806 dava direito "aos magistrados da polícia que obrigassem as mulheres solteiras, suspeitas de mau comportamento, a declarar sua gravidez e, se possível, a criar seus próprios filhos" (MARCÍLIO, 1998, p. 107). Observa-se, assim, que as mulheres continuavam sob a mira da sociedade no que se refere ao abandono de crianças ou pelo cuidado destas, compreendendo não mais apenas o viés inclusivamente religioso, mas também incluindo o judiciário. 
Acompanhando as mudanças europeias acerca da assistência à infância abandonada, Portugal busca uma "utilidade" para seus expostos. Com a secularização dos modelos de assistência - passando do domínio exclusivo religioso para o regime civil -, passando a administração das Rodas para as autoridades distritais, pequenas e pequenos portugueses abandonados adquirem, pela primeira vez na história do país, direitos respaldados pela lei, reconhecendo estas crianças como cidadãs portuguesas. Por fim, entende-se que "o sistema de assistência caritativa implantado em Portugal [...] foi o mesmo que se estabeleceu na colônia brasileira ao longo de sua História" (MARCÍLIO, 1998, p. 114), sendo que desde o século XVI crianças de camadas específicas da população portuguesa começaram a ser enviadas ao Brasil com vistas a "auxiliar" seu povoamento.

Conforme explica Fábio Pestana Ramos (2013, p. 19), “crianças também estiveram presentes à epopeia marítima", na condição de grumetes, pajens, órfãs do rei e ou simplesmente como passageiras, sendo que a maioria destas tinham em comum uma origem pobre e abandonada. Os grumetes eram crianças entre 9 a 16 anos, comumente encaminhadas para as expedições ultramar com a finalidade de realizarem serviços nas embarcações lusitanas, sendo que:

Para os pais destas crianças - consideradas um meio eficaz de aumentar a renda da família -, alistar seus filhos entre a tripulação dos navios parecia um bom negócio. Eles, assim, tanto podiam receber os soldos de seus miúdos, mesmo que estes viessem a perecer no além-mar, quanto livraram-se de uma boca para alimentar. Tampouco a alta taxa de mortalidade a bordo dos navios - algo em torno de 39\% dos embarcados - os assustava. Isso porque além de as crianças serem consideradas pouco mais que animais, a alta taxa de mortalidade em Portugal fazia com que a chance de morrer vítima de inanição ou de alguma doença em terra fosse quase igual, quando não maior do que a de perecer a bordo das embarcações. (RAMOS, 2013, p. 22, grifo nosso).

Outra forma de cooptar crianças para servirem como grumetes nas embarcações era o rapto de infantes de origem judaica, procedimento realizado a mando da própria coroa portuguesa para controlar o aumento de tal população em Portugal, sendo que "estas, ao contrário das recrutadas entre as crianças carentes portuguesas, eram jogadas nos navios à revelia de seus pais [...]” (RAMOS, 2013, p. 22). As funções desempenhadas pelos grumetes se remetiam a todo e qualquer cuidado com a embarcação e que normalmente deveriam ser executadas por homens adultos. Sofrendo com a viagem devido as péssimas condições em que se mantinham embarcados e com uma alimentação extremamente escassa, os grumetes também sofriam com a exploração sexual realizada por outros marujos adultos, mas também "alguns grumetes podiam mesmo prostituir-se como forma de obter proteção de um adulto" (RAMOS, 2013, p. 27). Já as crianças embarcadas como pajens, embora compartilhassem da mesma idade 
que os grumetes, realizavam funções menos pesadas e tinham maiores chances de alcançar um cargo superior na marinha portuguesa, recebendo um melhor pagamento se comparado com os grumetes. Sobre as origens dos pajens, tais crianças vinham de setores médios das cidades, por vezes sendo famílias pobres protegidas pela nobreza ou até mesma da baixa nobreza. Contudo, pressupõe-se que, contrariamente a finalidade de se enviar crianças às embarcações visando algum pagamento, os pajens eram inseridos por seus pais visando a ascensão social deste e de sua família, por ficarem mais próximos aos oficiais da marinha. Mas, ainda assim, tal proximidade e serviços mais selecionados "não impediam que os pequenos pajens corressem os mesmos riscos de estupros e sevícias, mudando apenas a condição do algoz: em vez de marujos, oficiais" (RAMOS, 2013, p. 30). Observa-se que a criança inserida na realidade das embarcações portuguesas era impelida a renunciar ao universo infantil para obter a ínfima possibilidade de sobrevivência durante as viagens.

As órfãs do rei eram meninas pobres retiradas dos orfanatos e que foram enviadas às colônias portuguesas a fim de "auxiliar" na constituição de famílias em tais locais, sendo que “estranhamente [eram] consideradas como órfãs até mesmo meninas que tinham apenas o pai falecido. [...] podemos supor que existiu uma espécie de sequestro de meninas pobres, principalmente menores de 16 anos, em Portugal" (RAMOS, 2013, p. 33). Estas, ao contrário dos grumetes e pajens, recebiam proteção de alguns religiosos que as acompanhavam nas viagens, a fim de proteger sua virtude, chegando ao Brasil aptas ao matrimônio. Ainda, com uma quantidade quase irrisória, encontravam-se crianças embarcadas como passageiras, as quais possivelmente acompanhavam seus parentes ou pais que, assim como as outras crianças a bordo, também sofriam com as consequências das expedições marítimas, a exemplo dos naufrágios recorrentes, nos quais as crianças morriam com maior facilidade por, simplesmente, serem esquecidas ou até mesmo abandonadas pela tripulação e parentes quando estes procuravam se salvar.

Ainda que "a história do cotidiano infantil a bordo das embarcações portuguesas quinhentistas foi, de fato, uma história de tragédias pessoais e coletivas" (RAMOS, 2013, p. 49), pressupõe-se que o embarque destas crianças e sua possível chegada à colônia pode ter dado início ao contingente de infantes desvalidos, como também com a prática de abandono comum em Portugal e que foi, porventura, culturalmente instalada no Brasil. 


\subsection{A legislação e a infância desvalida no Brasil Imperial}

Até o último decênio do Império, embora o país fosse um estado independente desde 1822, do ponto de vista jurídico e da vida civil, as referências doutrinárias e legais aqui vigentes ainda conservavam vínculos de referência com a antiga legislação do reino de Portugal. Tratase das Ordenações Filipinas, também conhecidas como Código Filipino, que sucederam as Ordenações Afonsinas e as Ordenações Manuelinas, respectivamente, sendo resultado da reforma jurídica desta última e servindo como referência doutrinária para os julgamentos e a formação de jurisprudência no Brasil nos anos de 1603 até 1916. Por ser uma compilação das leis portuguesas, as Ordenações Filipinas eram compostas de cinco livros, os quais foram organizados seguindo fontes subsidiárias ao direito português, sendo este influenciado pelo direito romano e pelo direito canônico em sua elaboração (OLIVEIRA, 2002).

O instrumento da tutela, em particular, existia desde o período colonial, conforme explica Azevedo (1996), e era utilizado para regularizar a situação de crianças órfãs de pai e mãe ou somente órfãs de pai com posses, uma vez que esse foi o modo encontrado pelos legisladores portugueses para assegurar a criação destas e a gestão de seus bens herdados na falta de seu pai ou quando este fosse considerado ausente. Contudo, “[...] o mecanismo da tutela foi estendido, de forma progressiva, ao universo das crianças pobres e pode-se sugerir que passou a ser utilizado para a constituição de criadagem compulsória" (AZEVEDO, 1996, p. 18). A contratação dos serviços de crianças desvalidas, à primeira vista, procurava atender ao propósito de educá-las por meio do trabalho prestado a um tutor que, a partir dessa contratação, passava ao lugar de responsável pela criação, alimentação, instrução de algum ofício, além de lhe dar abrigo e vestimenta.

Nesse sentido, Azevedo (1996) explica que a contratação de serviços de crianças desvalidas fora um meio de tratar sua própria situação, uma vez que ao pressupor-se que estas se encontravam em estado de abandono e/ou sofrendo maus tratos por parte de seus pais, com a adição de um estado de pobreza material e moral para cuidar de sua criação - sendo que os pobres eram, constantemente, associados a uma condição de ociosidade -, essa prestação de serviços teria como finalidade o encaminhamento da criança para uma vida estoica em sociedade, principalmente ao se pressupor que esta seria educada pelo trabalho. Contudo, "a argumentação do solicitante de estar 'preocupado com o bem estar do menor' camuflou, na maioria das vezes, outro interesse: o de ter crianças trabalhando gratuitamente para ele" (AZEVEDO, 1996, p. 21). Denominado como contrato de soldada que, segundo o vocabulário jurídico, soldada deriva da palavra soldo, tem como significação uma quantia paga ou também 
um salário de acordo com serviços prestados (SILVA, 2008). Assim, o contrato de soldada, a priori, fora instituído "a fim de legalizar o trabalho de crianças filhas de imigrantes" (AZEVEDO, 1996, p. 22), sendo essa locação de serviço mediada pelo judiciário, especificamente pelo juizado de órfãos.

As orientações para tutelar crianças em condição de orfandade (sem pai e/ou mãe) são encontradas no Livro IV das Ordenações Filipinas, Título CII, "Dos Tutores e Curadores, que se dão aos Orfãos":

O Juiz dos Orfãos terá cuidado de dar Tutores e Curadores a todos os Orfãos e menores, que os não tiverem, dentro de hum mez do dia, que ficarem orfãos; aos quaes Tutores e Curadores fará entregar todos os bens moveis e de raiz e dinheiro dos ditos orfãos e menores per conto e recado, e inventario feito pelo Scrivão de seu cargo, sob pena de privação do Officio. (ALMEIDA, 1870b, p. 994).

Ainda, nesse mesmo título, são encontrados dez parágrafos os quais tratam especificamente acerca do tipo de tutela que poderá ser solicitada e por quem. Também, como a mãe da criança, em especial, deveria proceder para requerer a tutela do próprio filho, uma vez que as Ordenações Filipinas foram organizadas de acordo com o que o direito romano determinava sobre o patriarcado, o qual reconhecia tão somente a autoridade de chefe de família como pertencente ao homem. Nos títulos CIII e CIV são encontrados, respectivamente, orientações acerca do procedimento de curatela ${ }^{32}$ e dos que se recusam a ser tutores (tendo sido indicados via testamento, sendo legítimos e então escolhidos pelo próprio juizado na falta desses dois). Observa-se que a legislação portuguesa da época pesquisada, mesmo que procurasse regulamentar o exercício da tutela de órfãos, apenas se detinha em um caráter prescritivo, não considerando as variadas possibilidades de interpretação da situação de orfandade da criança e da conjuntura de infância na época.

Sobre a realização do pagamento das soldadas, encontra-se no Livro IV das Ordenações Filipinas, Título XXXI, "Como se pagarão os serviços e soldadas dos criados que não entraram a partido certo", parágrafo 8 , as seguintes diretrizes ${ }^{33}$ :

$\mathrm{E}$ as ditas soldadas vencerão os machos sendo de quatorze anos perfeitos, e as fêmeas de doze. E não chegando a dita idade, vencerão o que parecer ao Julgador, não das ditas quantas, mas dimuindo-lhes delas o que for justo. $\mathbf{E}$ aos moços ou moças pequenos, menores de sete anos, não se julgará soldada alguma porque a criação que se neles faz lhes deve ficar por satisfação de qualquer serviço que fação. (ALMEIDA, 1870, p. 809, grifo nosso).

\footnotetext{
${ }^{32}$ Curatela, na legislação do período pesquisado, referia-se ao poder legal atribuído para alguém no cuidado de uma pessoa já considerada maior de idade e de seus bens, uma vez que esta não seja considerada apta para tal.

${ }^{33}$ Cf. Livro I das Ordenações Filipinas, Título LXXXVIII, parágrafos 13 a 21; Cf. Livro IV das Ordenações

Filipinas, Títulos XXIX, XXX, XXXI, XXXII, XXXIII, XXXIV, XXXV, LII e LIV.
} 
Sobre as Ordenações Filipinas e a contratação de serviços de crianças desvalidas, Ariza (2015) comenta que tal legislação estabeleceu referências para o exercício do trabalho das crianças desvalidas, como também para uma possível ruptura do contrato e como proceder diante essa circunstância. De acordo com as ordenações, ao estarem na condição de contratadas, essas crianças estavam sujeitas aos moldes de remuneração como os de criados adultos e outros trabalhadores subordinados ao que se refere à prestação de serviços, ou seja, com:

[...] baixas remunerações, consignação dos pagamentos ao final do prazo estabelecidos para a prestação de serviços, rigidez do controle exercido por amos ou senhores, presunção da má fé e indolência de trabalhadores, naturalmente inclinados a ludibriar empregadores e escapar dos serviços. (ARIZA, 2015, p. 4).

Contudo, Ariza (2015) conclui que nenhuma publicação oficial produzida antes e durante o Império para orientar o trabalho de crianças durante o século XIX fora, de fato, esclarecedora para regulamentar e organizar o uso dessa força de trabalho infantil.

Ao também trabalhar com processos de tutela e contratos de soldada, Patrícia Ramos Geremias (2015) busca utilizar tais fontes para compreender a possível relação entre os encaminhamentos providos pelos documentos com a organização estrutural, social e econômica da prática de tutela e soldada para a manutenção do trabalho doméstico infantil desde o período colonial ao republicano. A autora sugere que essas fontes sejam objeto para investigar o elo histórico entre a infância desvalida e a produção de empregados domésticos no Brasil, focando as "formas de trabalho infantil consideradas mais perigosas e degradantes, como o trabalho nas fábricas, ruas e minas" (GEREMIAS, 2015, p. 10), como também incluir "as crianças nos estudos sobre o trabalho doméstico no século XIX, que tem centrado sua atenção majoritariamente no trabalho desempenhado pelos adultos, especialmente pelas mulheres adultas" (GEREMIAS, 2015, p. 10). Geremias (2015) explica que se deve explorar de modo investigativo os processos não tendo apenas a referência da Lei do Ventre Livre (BRASIL, 1871), mas também o costume da criação de crianças alheias com a finalidade de se utilizar dos serviços das mesmas.

A obra Primeiras linhas sobre o processo orphanologico, de José Pereira de Carvalho, surge, em 1879, buscando esclarecer os procedimentos a serem seguidos a respeito de órfãos e crianças desvalidas. Tomando as mudanças significativas que ocorreram na sociedade brasileira no período pesquisado, principalmente no que se refere ao aumento da população e, consequentemente, o de crianças em condições de abandono ou então órfãs, a elaboração dessa obra surgiu como um "guia" voltado para orientar no funcionamento e na atuação do juizado de órfãos, principalmente nos procedimentos para tratar as crianças desvalidas. 
De acordo com o vocabulário jurídico (SILVA, 2008), tutelar alguém é ter incumbência legal e/ou judicial conferida a uma pessoa que deverá administrar os bens e/ou a conduta do tutelado através da elaboração de um auto de tutela, o qual corresponde a uma das peças produzidas no decorrer de um processo judicial e que determina a diligência administrativa e/ou judicial de uma autoridade responsável. Por comparação, a legislação brasileira do século XIX definia quatro tipos de tutela, sendo que três delas (testamentária, legítima ou dativa) constam nos primeiros parágrafos do Capítulo XVIII - "Dos tutores", da obra Primeiras linhas sobre o processo orphanologico:

$\S 113$ Pouca utilidade resultaria do inventário e partilha se as pessoas e os bens dos órfãos ficassem em abandono. E para cuidar daqueles e destes que se dão tutores e curadores.

$\S 114$ Os tutores ou são testamentários, ou legítimos, ou dativos.

$\S 115$ Preferem na tutela os tutores testamentários, sendo idôneos, e tendo sido feita a sua nomeação em testamento solene e por pessoa legítima.

$\S 116 \mathrm{Na}$ falta da tutela testamentária tem lugar a legítima, e preferem nela aqueles, a quem a lei devolve a sucessão.

$\S 117 \mathrm{Na}$ falta da tutela testamentária e da legítima, tem lugar a dativa. (CARVALHO, 1880 , p. 5).

A tutela testamentária ocorria quando o pai da criança, ao falecer, deixava em seu testamento uma indicação de quem deveria se tornar tutor desta, cuidando de sua pessoa, assim como da administração e gestão de seus bens herdados ${ }^{34}$. A tutela legítima ocorria nos casos em que não havia um testamento com uma indicação de sujeito para ocupar o cargo de tutor, sendo este assumido de acordo com a lei de sucessão familiar ${ }^{35}$, contemplando-se os parentes mais próximos da criança e preferencialmente aos homens. Já a tutela dativa ocorria nos casos em que a criança não tinha parentes próximos para realizar tais cuidados, levando o juizado de órfãos a incumbir essa responsabilidade a um homem capaz de zelar pela pessoa e pelos bens da criança. A tutela dativa também era estabelecida nos casos de não reconhecimento pelo judiciário da autoridade moral dos pais da criança, ou seja, no caso destes não serem considerados dignos e com condição financeira adequada - no caso de o pai estar vivo -, ou então com pai falecido e mãe viva, sendo esta considerada pela lei como não apta para cuidar de seus próprios filhos ${ }^{36}$. Ainda, exista a tutela ad hoc (em latim, "para essa finalidade"), estabelecida de modo provisório, no qual o tutor nomeado realizaria sua função por um tempo determinado e/ou até que se encontrasse um tutor definitivo. Ao longo da obra, observa-se mais

\footnotetext{
${ }^{34}$ Cf. Livro IV das Ordenações Filipinas, Título CII, parágrafos 1 e 2.

${ }^{35} \mathrm{Cf}$. Idem, parágrafos 3, 4, 5 e 6.

${ }^{36}$ No caso de a mãe ser indicada via testamento para ser a tutora de seus filhos, esta deveria seguir uma série de regulamentações previstas pelas Ordenações Filipinas, por conta das quais deveria constantemente comprovar viver honestamente, não se casar novamente, entre outras.
} 
passagens nas quais poderiam ser encontradas as obrigações dos tutores para com seus tutelados, a exemplo do tempo em que o tutor eleito iria exercer tal função, que tipo de pessoas não poderiam ser eleitas como tutoras, as situações em que uma pessoa eleita para a tutela dativa de uma criança poderia recusar o cargo, como também em que poderia ser removida do mesmo, a prestação de contas que o tutor deveria fazer da pessoa e dos bens do tutelado, entre outras.

A obra de José Pereira de Carvalho tornou-se um marco para a compreensão e tratamento do problema da orfandade, menoridade e abandono de crianças no século XIX. A primeira edição fora lançada em 1879 e 1880, em dois volumes, contendo a legislação específica e jurisprudência da época tendo o ano de 1879 como data limite, realizando inferências no formato de notas de rodapé onde é possível observar sua finalidade de complementação em favor das Ordenações Filipinas, como por exemplo, especificamente onde encontrar sobre tal assunto nas compilações das leis portuguesas. Já a segunda edição fora lançada em 1888, contendo praticamente a mesma legislação e comentários da primeira edição, mas com uma significativa alteração e adição referentes a duas leis abolicionistas. De 1871, a Lei Rio Branco, mais conhecida como a Lei do Ventre Livre (BRASIL, 1871), a qual determinou a liberdade de todas as crianças nascidas após esta data em ventre escravo e a de 1888 (a de maior significado), a Lei Áurea (BRASIL, 1888), a qual extinguiu a escravidão no Brasil. Também nessa segunda edição da obra Primeiras linhas sobre o processo orphanologico, podese encontrar textos complementares, dedicados à orientação de Juízes de Órfãos no tratamento de um órfão quando este era considerado como uma criança abandonada.

Especificamente sobre as alterações na obra de José Pereira de Carvalho no que se refere sobre como os juízes deveriam proceder com uma criança órfã/abandonada, eis a recomendação para quando esta, tanto nacional quanto estrangeira, fosse encontrada vagando pelas ruas desamparada e desprotegida, sendo recolhida pela polícia da corte:

I - Solicitar ao ajudante-general do exército, ou da armada, ou diretor do arsenal da guerra a admissão dos mesmos menores em qualquer das companhias de aprendizes da guerra ou da marinha;

II - Requisitar ao ministério do Império, quando não possam ser ali aceitos, para que sejam admitidos no asilo dos meninos desvalidos;

III - Dar soldada aos menores órfãos, filhos de pais incógnitos (Ord. Livro $1^{\circ}$, Título 88, § 13, disposição do Aviso nº. 312 de 20-10-1859) [...]. Convém, entretanto, que os menores dados a soldada sejam entregues somente a pessoas domiciliadas no distrito da jurisdição desse juízo, preferindo a Vossa Senhoria os estabelecimentos industriais e exercendo toda vigilância no empenho de verificar se são cumpridas as condições impostas nos termos da responsabilidade. (CARVALHO, 1888, apêndice, grifo nosso).

Antes da tutela ser estabelecida como um instituto jurídico no Brasil ao qual se recorria para reconhecer a criação de crianças consideradas órfãs, Marcílio (1998) nos explica que “o 
costume de criar um filho alheio nas famílias foi amplamente difundido, aceito e valorizado" (MARCÍLIO, 1998, p. 136), principalmente por estar inspirado na caridade cristã, uma vez que a "própria Igreja, desde tempos primitivos, estimulou a prática da caritas, do amor ao pobre e às criancinhas, prometendo a salvação futura para os que a praticavam" (MARCÍLIO, 1998, p. 136). Contudo, a autora comenta que tal conduta não era explicada apenas por seu teor religioso, uma vez que "em uma sociedade escravista (não-assalariada), os expostos incorporados a uma família poderiam representar um complemento ideal de mão-de-obra gratuita" (MARCÍLIO, 1998, p. 137). Observa-se que no século XIX, a tutela guardou resíduos do escravismo, uma vez que, ainda formalmente consideradas livres, diversas crianças filhas de escravos nascidas após a Lei do Ventre Livre (BRASIL, 1871) não puderam evitar a posse de suas vidas e força de trabalho, já que tal liberdade não era extensiva aos seus pais e nem muniam suas famílias com meios para criarem seus filhos. Por conseguinte, a relação contratual de tutela firmada entre as crianças filhas de escravos e tutores com o recebimento de uma remuneração tornouse prática comum na forma do contrato de soldada. Além da geração de crianças nascidas após a Lei do Ventre Livre, tal prática tornou-se frequente entre famílias desvalidas e contratantes. Desse modo, desde meados do século XIX, fato acentuado pela Lei do Ventre Livre, era comum estabelecer uma relação contratual entre meninas e meninos, algum familiar - muitas vezes a mãe - e um adulto para quem prestariam serviço e receberiam a remuneração previamente firmada entre as partes.

O engajamento de uma criança para a tutela sem a contratação de seu serviço era prática comum nas camadas mais abastadas da sociedade, sendo realizada quando esta perdera os pais, tornando-se órfã. Apesar do evidente sentido de perda do pai e da mãe, a denominação "órfão" também era utilizada para designar uma criança ainda com pais vivos, mas que não detinham de recursos financeiros e, principalmente, morais para a criação de seus filhos, uma vez que a pobreza estava associada aos vícios e a ociosidade (BASTOS, 2012). A exemplo das possibilidades de criação e educação de crianças, tais orientações também se detinham sobre o direito do pátrio poder, no qual a mulher/mãe não era considerada como competente para exercer tais funções, não tendo direito sobre seus próprios filhos na falta do pai. Porém, com Decreto $n^{o}$. 181, de 24 de janeiro de 1890 (BRASIL, 1890), o qual promulgou sobre o casamento civil, a mulher passa a ter permissão pela lei para se tornar responsável por seus filhos apenas quando solteira ou viúva e manter-se em tal estado civil. Ao casar-se novamente - no termo da época, tornar-se "binuba" -, a mulher passava, novamente, a perder o direto sobre seus filhos, conforme se pode observar no artigo 94 do referido decreto: 
Todavia, si o conjuge fallecido for o marido, e a mulher não for binuba, esta lhe succederá nos seus direitos sobre a pessoa e os bens dos filhos menores, emquanto se conservar viuva. Si, porém, for binuba, ou estiver separada do marido por culpa sua, não será admittida a administrar os bens delles, nem como tutora ou curadora. (BRASIL, 1890, grifo nosso).

Segundo a historiografia apresentada até o momento, a infância desvalida fora comumente associada ao contrato de soldada, uma vez que esse seria um encaminhamento viável para crianças em condição de pobreza. Assim, para compreender o processo de incorporação do contrato de soldada sobre a infância desvalida, é necessário voltar no tempo, nas ações e na legislação restritiva para a escravidão, uma vez que tais assuntos estão relacionados.

A primeira delas fora o tratado assinado entre Brasil e Reino Unido, a Bill Aberdeen, que teve seu prazo de implantação esgotado em março de 1845. A Bill Aberdeen deu o direito aos britânicos de aprisionar as embarcações negreiras e julgar seus comandantes, atracar navios brasileiros em alto mar a fim de verificar se estes transportavam escravos e, em caso positivo, devolvê-los à África ou transferi-los para navios britânicos, mesmo tudo isso ocorrendo em águas brasileiras. O tratado assinado gerou transtornos comerciais aos traficantes e proprietários de escravos, uma vez que estes eram os responsáveis pela maior parte da força de trabalho empregada na sociedade e, por isso, pela manutenção da economia (MOTTA, 2012). Paradoxalmente, os termos da Bill Aberdeen geraram um aumento significativo no comércio de escravos, antecipando compras e vendas de negras e negros antes da proibição definitiva, como também por conta do aumento de preço de escravos comercializados de forma clandestina. Ainda, gerou o tráfico interno pelos quais os antigos traficantes comercializavam escravos que trabalhavam na agricultura que se encontrava decadente, com os engenhos de açúcar, para exercerem sua força de trabalho nas lavouras de café na região Centro-Sul, a qual se encontrava em plena expansão econômica. Assim, a Bill Aberdeen levou o governo brasileiro a aprovar a Lei Eusébio de Queirós ${ }^{37}$ (BRASIL, 1850), a qual ordenou a proibição do tráfico interatlântico de escravos através da pressão feita pelo Reino Unido para que o Brasil cessasse o tráfico negreiro, pressupondo-se como medida imediata a utilização de mão-de-obra assalariada em todo o território. Assim, o sistema escravista começou a ser enfraquecido no Brasil graças a movimentação de militantes abolicionistas, gerando uma grande preocupação não somente nos proprietários de escravos, mas também no próprio governo, uma vez que este tinha a noção de que grande parte da manutenção da economia do país se encontrava nas mãos e na força de trabalho exercida pelas negras e negros (MOTTA, 2012).

\footnotetext{
${ }^{37}$ BRASIL. Lei no ${ }^{\circ}$ 581, de 4 de setembro de 1850 .
} 
Em 28 de setembro de 1871 entrou em vigor outra lei abolicionista brasileira: a Lei Rio Branco, mais conhecida como Lei do Ventre Livre (BRASIL, 1871). Essa lei tinha como finalidade tornar todas as crianças nascidas em ventre escravo como livres após essa data. Essa lei ensejava abolir a escravidão no país de forma gradual, a qual previa a transição do trabalho escravo para o livre e remunerado de forma que não gerasse tantos transtornos para os grandes senhores de escravos. Ainda, utilizava como justificativa a própria situação de escravidão de negras e negros para essa transição - lenta, diga-se de passagem -, uma vez que estes mesmos senhores, como também grandes nomes do direito português e brasileiro argumentavam sobre o fato de que seria um choque para os escravos serem libertados e inseridos na sociedade brasileira de forma repentina, necessitando de uma transição na sociedade brasileira para que tal ideia fosse melhor acolhida por esta (ZERO, 2004). Ainda que a Lei do Ventre Livre fora concebida após um conjunto de discussões e pressões de abolicionistas para que a escravidão fosse completamente cessada em todo território, deve-se atentar ao fato de que esta também fora concebida como subterfúgio para organizar o mercado e a economia (ZERO, 2004). Zero (2004) explica que pelas determinações da Lei do Ventre Livre, mesmo que a criança nascida de mãe escrava tivesse direito a sua liberdade a partir de 28 de setembro de 1871, esta permaneceria com o dono de seus pais até completar 8 anos de idade, ficando a cargo do senhor lhe prover medidas de cuidado e educação. Após a criança atingir a idade estipulada, esse mesmo senhor teria a opção de receber do governo uma indenização de $600 \$ 000$ réis em títulos com o rendimento de $6 \%$ por cada criança que estava sob seu poder e que chegasse ao oitavo ano de vida ou poderia optar em utilizar os serviços dessa mesma criança até que esta completasse 21 anos. A lei concebeu também o chamado Fundo de Emancipação a partir de seis loterias anuais e um décimo do rendimento de outras, um imposto sobre os escravos e um tributo acerca da transferência de escravos de um senhor para outro, sendo tal renda gerada visando um fundo disponível para libertar os que ainda permaneciam em situação de escravidão. Ainda, essa mesma lei elaborou comunidades emancipadoras com vistas a libertar as negras e os negros que ainda eram mantidos como escravos pertencentes ao Estado, como também os escravos que fossem integrantes de alguma herança não reclamada e aqueles que foram abandonados por seus donos. Assim, pelo advento de libertação das crianças nascidas após a decretação da Lei do Ventre Livre, a "transição para o trabalho livre ocorria sob o controle dos donos dos escravos, pois [...] teriam o tempo necessário para ajustarem as suas fazendas ao novo sistema de trabalho, ou seja, a abolição não ocorreria de forma imediata e total" (ZERO, 2004, p. 62). 
Pode-se entender que essa forma gradual de abolição da escravidão no Brasil além de procurar não gerar transtornos para os grandes proprietários de escravos, tinha também como finalidade o disciplinamento da população escrava. E mais: ainda que essa forma gradual de abolição fosse divulgada a partir de toda uma campanha em prol do pensamento abolicionista, é de extrema importância compreender as artimanhas preparadas para manter os escravos presos nas amarras de seus senhores e do governo. Ou seja, é possível constatar que, na verdade, a Lei do Ventre Livre nada mais era do que uma forma de prolongar o período escravista e protelar o seu desfecho (ZERO, 2004). Assim, complementa a autora citada anteriormente que "a lei [...] foi responsável pela transformação da tutela em um instrumento de controle social e econômico dos novos atores criados por elas, os ingênuos" (ZERO, 2004, p. 64), uma vez que a escravidão dava sinais de que estava perto do fim, ainda que "as crianças 'libertadas' pela Lei do Ventre Livre, em 1888 [...] não teriam atingidos 21 anos. Desta forma, a lei criou escravos disfarçados [...]” (ZERO, 2004, p. 75). Kátia de Queirós Mattoso (1988), ao discutir esta mesma lei, dialoga especificamente sobre essas crianças e afirma que "sob suas aparências enganadoras, a lei do ventre livre é [...] a mensagem simbólica do olhar que um corpo social inteiro levanta sobre a criança escrava. A Lei do Ventre Livre é o triunfo das mentalidades antiquadas e perversas" (MATTOSO, 1988, p. 55).

Além da legislação que antecedeu a abolição definitiva, havia outro tipo de legislação que regulava certos usos do trabalho compulsório (BASTOS, 2012), a exemplo da Lei de 13 de setembro de 1830, a qual "regula o contrato por escrito sobre prestação de serviços feitos por brasileiro ou estrangeiro dentro ou fora do Império" (BRASIL, 1830); a Lei $n^{o}$. 108, de 11 de outubro de 1837, "dando várias providências sobre os contratos de locação de serviços dos colonos" (BRASIL, 1837); e o Decreto $n^{o} .2 .827$, de 15 de março de 1879 (BRASIL, 1879), o qual estava "dispondo o modo como deve ser feito o contrato de locação de serviços", sendo apenas nos dois últimos encontrados apontamentos acerca da contratação de sujeitos com menos de 21 anos de idade, na condição ou não de órfãos. Por fim, tais leis e decreto acima citados são revogados pelo Decreto $n^{o}$. 1.313, de 17 de janeiro de 1891 (BRASIL, 1891), que "estabelece providencias para regularizar o trabalho dos menores empregados nas fabricas da Capital Federal” e sendo estendida para outras regiões do país. Não obstante haver legislação nacional acerca da contratação dos serviços alheios, ainda que exígua, de modo geral, as decisões do judiciário no que se refere ao destino da infância pobre até então continuavam orientadas pela doutrina das Ordenações Filipinas.

Ao explicar sobre os fatores que influenciaram a elaboração do Código Civil de 1916, Claúdio De Cicco (1993) discorre acerca de dois momentos decisivos para tal, sendo estes a 
alteração da forma de governo e as renovadas conjunturas sociais e econômicas do final do século XIX e início do século XX. Mesmo com a proclamação da Independência do país, em 1822, as Ordenações Filipinas continuaram em vigor no Brasil conforme já afirmado anteriormente -, apenas sendo revogadas algumas das disposições que estavam baseadas na condição do Brasil ser colônia de Portugal. Contudo, foi na Constituição do Império do Brasil, em 1824, em que o início da organização política brasileira dava sinais de mudança. $\mathrm{Na}$ constituição de 1824, em seu artigo 179, inciso XVIII, é contemplada a necessidade em "organizar-se-ha quanto antes um Código Civil, e Criminal, fundado nas solidas bases da Justiça, e Equidade”. Ainda, foi com a elaboração desta que o Império passa a existir juridicamente, determinando "a forma de governo (monárquico), a forma de estado (unitário), a divisão do território nacional (em províncias), a cidadania (para os nascidos no Brasil), [mais] a capacidade de intervenção do Estado [...]” (DE CICCO, 1993, p. 99). Com a instalação da República, em 1889, uma nova ordem de progresso e elitização da sociedade brasileira era impulsionada, mantendo-se em uma "filosofia liberal por excelência no Brasil: individualista, evolucionista, racionalista e, ao mesmo tempo, conservadora" (DE CICCO, 1993, p. 117). Assim, a transição do regime imperial para o republicano trouxe consigo perspectivas de atenuar possíveis obsolescências ainda prescritas na legislação anterior ao Código Civil de 1916. Com a valorização da cultura cafeeira, gerando um crescimento industrial e urbano, especificamente na região de São Paulo, as conjunturas sociais e econômicas da época tomaram nova forma e suscitaram a importância da elaboração concreta do primeiro Código Civil brasileiro. Ainda, a intensa influência internacional que se tornava cada vez mais constante na sociedade brasileira - culturalmente modelada pela Europa - provocou ares de mudança nos grandes centros urbanos no país que consideravam a implantação do código algo emergencial para seu progresso (DE CICCO, 1993).

O primeiro Código Civil brasileiro (BRASIL, 1916) ${ }^{38}$, foi idealizado no início de 1889 e finalizado no final do mesmo, sendo aprovado pelo Senado Federal em 1912, promulgado em 1916 e, finalmente, tendo o início de sua vigência em 1917. O responsável pelo projeto do primeiro Código Civil brasileiro foi Clóvis Beviláqua, jurista e legislador formado pela Faculdade de Direito de Recife, tornando-se também ao longo de sua carreira historiador e professor de filosofia e legislação, respectivamente, na mesma instituição onde se formou. Elegeu-se como deputado para a Assembleia Legislativa do Ceará, cooperando de modo ativo na elaboração da constituição estadual. Beviláqua já versava em outras obras do Direito, como

${ }^{38}$ Lei ${ }^{\circ} .3 .071$, de $1^{\circ}$ de janeiro de 1916. 
"Direito das Sucessões" (1899), "Direito das Obrigações" (1896), "Criminologia e Direito" (1896) e "Direito de Família" (1896), sendo essa última obra também citada em alguns dos processos selecionados para o desenvolvimento dessa pesquisa. Divulgado e prometido a partir de um modelo de liberalismo e progresso, deve-se atentar ao fato de que a elaboração do primeiro Código Civil brasileiro ocorrera em um país marcado pela escravidão. Com isso, ao entender os valores de uma população e como tais foram construídos, é possível observar já no próprio Código Civil seus reflexos. O primeiro Código Civil brasileiro se apresentou individualista, uma vez que, para Beviláqua, ser um sujeito de direito estava completamente ligado ao fato desse sujeito usufruir de patrimônios - sejam estes patrimônios ligados à bens físicos ou até mesmo a (insistente) influência do pátrio poder ao homem, chefe de família, sobre sua esposa e filhos (ALBA, 2004).

Pelo código de Beviláqua é possível observar que o pátrio poder ainda era vigente como um conjunto de direitos e responsabilidades do pater familias, sempre ocupado por uma posição masculina e mantendo-se como a posição mais elevada no estatuto familiar. Ainda que alguns pouco artigos procuravam atenuar a situação da mulher como subordinada ao marido, essa ainda era vista com incapaz juridicamente, além de ter mais deveres do que direitos dentro do casamento $^{39}$. É de domínio público que durante a época citada, as mulheres ainda viviam sob a penumbra da sociedade e completamente julgadas por seus atos, já que no período buscava-se constituir a sociedade pelo modelo familiar patriarcal, revelando assim uma grande contradição entre os princípios designados pelos militantes pró-código e o verdadeiro pensamento dos que o elaboraram.

A exemplo destas contradições, especificamente nas condições e possibilidades de a mulher/mãe solicitar a tutela de seu próprio filho, observa-se durante a vigência das Ordenações Filipinas que essa condição privilegiava explicitamente o homem/pai - ainda que em um parágrafo é explicado sobre a possibilidade de a mãe e/ou avó tornarem-se as tutoras desde que comprovassem viver honestamente e ter condições financeiras para tal. Assim, mesmo com o já citado Decreto $n^{o}$. 181, de 24 de janeiro de 1890 (BRASIL, 1890), no qual as mulheres tornavam-se aptas ao exercício da tutela de seus próprios filhos desde que se mantivessem viúvas, observa-se que o primeiro Código Civil brasileiro, em seu artigo 409, ainda dava a prioridade ao homem em relação a mulher:

Em falta de tutor nomeado pelos pais, incumbe a tutela aos parentes consangüíneos do menor, por esta ordem:

\footnotetext{
${ }^{39}$ Cf. Lei $n^{\circ}$. 3.071, de $1^{\circ}$ de janeiro de 1916, Código Civil dos Estados Unidos do Brasil, artigos 6, 233, 234 , 240, 242, 243, 247, 248, 251, 252, 329, 393, 407, 409.
} 
I - Ao avô paterno, depois ao materno, e, na falta deste, à avó paterna, ou materna; II - Aos irmãos, preferindo os bilaterais aos unilaterais, o do sexo masculino ao do feminino, o mais velho ao mais moço;

III - Aos tios, sendo preferido o do sexo masculino ao do feminino, o mais velho ao mais moço. (BRASIL, 1916, grifo nosso).

Pode-se constatar que poucas mudanças relativas ao direito da mulher sobre seus próprios filhos realmente poderiam ser consideradas como significativas, tanto para o judiciário quanto para a sociedade. Ainda, uma vez que a alteração primordial para que novas leis fossem, de fato, compreendidas em sua necessidade, era necessário algo muito mais difícil e que sempre se mostrou resistente: mudança de valores (e que de preferência não se envolvessem com questões religiosas), compreensão das subjetividades e dos diferentes contextos familiares e de infâncias que se encontravam em transição, considerando o período pesquisado.

\subsection{Observações sobre a infância nos processos judiciais}

Considera-se que os casos reconstituídos a partir da consulta aos processos selecionados na amostra que compõe o conjunto de fontes estudadas nesse trabalho contenham indícios de que a noção de criação, controle e supervisão sobre as crianças consideradas propensas à uma falta de educação moral passou a ser regular não apenas no campo jurídico, mas também no cotidiano dos sujeitos encontrados nos processos. Ainda, o exame dos documentos revela que, na maioria das vezes, as crianças realizavam trabalhos domésticos e eram apresentadas como objeto de caridade de seus tutores, sendo apenas tuteladas (e não cuidadas) ou até mesmo contratadas. E, elencando um dos detalhes que fizeram toda a diferença na análise e compreensão de conteúdo dos processos foi o fato constatado de que pouquíssimas foram as vezes em que as crianças tiveram seus depoimentos recolhidos e considerados na decisão judicial acerca de seus destinos. Pressupõe-se, ainda, que esse detalhe é decorrente do tratamento e qualificação da infância na época pesquisada, principalmente a desvalida.

A infância, no singular, pode ser entendida como a apresentação idealizada de crianças e suas características de modo que fundamentem um tipo ideal, como também há a subdivisão em infâncias, no plural, uma vez que é possível tratar sobre uma infância desvalida - como é o caso desse trabalho -, uma infância pobre, abandonada, marginal, delinquente, entre outros (FREITAS; KUHLMANN JR., 2002). Ainda, "às vezes, a expressão infância refere-se às crianças dos setores dominantes, quando se atribui a esses setores a primazia dos sentimentos e das práticas que caracterizam este conceito ou representação" (FREITAS; KUHLMANN JR., 2002, p. 8). A compreensão dessa conceitualização torna-se profícuo para esse trabalho, sendo 
possível conjecturar que a especificidade da infância desvalida é utilizada como premissa para a ocorrência e produção dos processos e como também produto da própria situação de marginalização desta pelo judiciário da época, sendo que esta, acredita-se, pavimentou os subsídios para prática de silenciamento pelas/das crianças nos processos selecionados.

O uso da expressão desvalida nesse trabalho justifica-se pela definição do termo que, a rigor, designa aquele que se encontra sem valimento ou valia, desprotegido, desamparado, desgraçado, miserável, sem merecimento (FERREIRA, 2004). Entende-se, nesse trabalho, que o uso de criança desvalida e/ou infância desvalida contempla a discussão em torno dos sujeitos encontrados principalmente nos processos de tutela e contratos de soldada, uma vez diante de suas variadas condições de orfandade, abandono, desamparo e desproteção.

O fato das crianças não terem voz sobre seus próprios destinos não é novidade na história. O silenciamento da criança perdurou até a sociedade medieval, no qual o sentimento de infância que conhecemos hoje não existia. É claro que tal sentimento, assim que surgido, também se modificou e se fortaleceu ao longo dos séculos. Contudo, esse silenciamento não significava o negligenciamento, abandono ou desprezo, mas estava relacionado às particularidades da infância, do que distinguiria, de fato, uma criança de um adulto. Philippe Ariès (1981) nos explica que assim que uma criança demonstrava capacidade de viver sem a necessidade e interferência de sua ama ou de sua mãe, ela era estabelecida dentro do mundo dos adultos, não sendo mais distinguida como diferente. Ariès (1981) também nos explica que a criança muito pequena, frágil e cheia de demandas necessárias para sua sobrevivência simplesmente "não contava". Esse sentimento de nulidade para com a criança pequena ocorria pelo fato de que esta teria poucas chances de sobreviver, tomando como premissa as possíveis condições de higiene, alimentação e cuidados da época. Contudo, "assim que a criança superava esse período de alto nível de mortalidade, em que sua sobrevivência era improvável, ela se confundia com os adultos" (ARIÈS, 1981. p. 157).

Não se sabe, ao certo, quando o sentimento de infância passou a ser percebido, mas é de conhecimento público que entre os séculos XVI e XVII as crianças passaram a serem mais retratadas em pinturas, provocando, lentamente, novos sentimentos relacionados à infância, uma vez que essas crianças "insistiam" em continuar a viver mesmo diante de péssimas condições. Assim, a fragilidade deu lugar para a tenacidade. Com isto e pelo aumento do convívio com as crianças - logo, maior interação com estas -, o sentimento de "paparicação", segundo Ariès (1981), sugira em detrimento de fatores relacionados a ingenuidade, graça e gentileza das crianças, tornando-se fonte de distração e relaxamento para os adultos. Anteriormente, esse encantamento com as crianças restringia-se a suas amas e mães, porém 
“[...] as pessoas não hesitariam mais em admitir o prazer provocado pelas maneiras das crianças pequenas, o prazer que sentiam em "paparicá-las"” (ARIÈS, 1981, p. 158).

Para entender a implicância em ser uma criança desvalida no período pesquisado, se faz necessário enfatizar as mudanças de ordem social, política e econômica da época, sendo elas: sociais, com a abolição da escravidão; políticas, com a mudança do regime imperial para o republicano; e econômicas, com a abolição do trabalho escravo para o trabalho livre remunerado (BASTOS, 2012). Sobre os desdobramentos das leis abolicionistas e, especificamente, a abolição da escravidão no país, tais foram atenuantes para a manutenção de uma classe dominante sobre a permanência de ex-escravos na extrema pobreza e miséria do que, de fato, se preocupar com a liberdade da população negra. Como já citado anteriormente, antes da abolição da escravidão, uma das leis abolicionistas que a antecedeu foi a Lei do Ventre Livre (BRASIL, 1871), a qual decretou a liberdade para todas as crianças nascidas em ventre escravo. Contudo, essa lei previa que o senhor dono de escravos poderia tutelar a criança nascida livre com o intuito de usufruir de seus serviços. Assim, tal criança deveria prestar serviços ao senhor de seus pais como modo de pagar por sua criação, alimentação, educação, entre outros.

É importante também observar, conforme visto pelas referências utilizadas por esse trabalho, como também pelas análises de alguns processos utilizados como fontes, que mesmo as crianças de classes mais abastadas pouco tinham a oportunidade de contribuir com o processo a partir de seus depoimentos e, quando ouvidas, seus relatos serviriam, na maioria das vezes, como instrumento de manobra arbitrária para a decisão do juiz. Ainda, observou-se que tal situação ocorria com as crianças desvalidas e que eram contratadas: estas só teriam oportunidade de serem ouvidas caso o processo fosse aberto na tentativa de indicar algum tipo de mau trato ou não pagamento por parte do contratante, sendo que essa oportunidade era majoritariamente desconsiderada. Observa-se, também, a implicância sobre a pobreza e, consequentemente, a educação da criança: se esta mostrasse "aplicação", ou seja, demonstrasse que o investimento de seu tutor sobre ela valeria a pena, a criança, quem sabe, teria maiores condições de ser ouvida. Pressupõe-se que do silenciamento pela sobrevivência pouco provável na sociedade medieval, a criança desvalida não merecia ser ouvida por sua simples condição socioeconômica.

Ainda em relação ao silenciamento das crianças nos processos, a historiografia que se ocupou de tema semelhante indica a prevalência do discurso jurídico que, possivelmente, era realizado pelas classes mais abastadas, uma vez que é de conhecimento público que foram estas a terem acesso com maior facilidade ao conhecimento legislativo e formação sobre determinado 
assunto. Luciana de Araujo Pinheiro (2003) disserta sobre as proposições e ações elaboradas para a criança pobre entre os anos 1879 e 1889, estudando a problemática dessa infância pela atuação dos chefes de polícia da corte, ministros da justiça, presidentes da província do Rio de Janeiro e os juízes de órfãos da capital. Em seu trabalho, Pinheiro (2003) explica que os discursos policiais e ministeriais do juizado de órfãos poderiam corroborar essa dominância da elite no discurso jurídico. Contudo, ao mesmo tempo, a autora observa através das análises realizadas pelas concessões de tutela que "apesar das sucessivas tentativas de submissão e controle das classes populares por dirigentes e intelectuais, a infância pobre da Corte continuou subsistindo e habitando a capital imperial, e mais tarde republicana" (PINHEIRO, 2003, p. 136). Assim, observa-se uma luta e resistência por parte da infância pobre contra o judiciário e a elite que visavam seu controle, vigilância, encaminhamento à tutela ou punição.

Em sua dissertação de mestrado, Alessandra David (1997) busca apurar acerca da conjuntura de crianças desvalidas no contexto da cidade de Franca, interior do Estado de São Paulo, entre os anos de 1850 e 1888. Também tendo processos de tutela como corpus principal para o estudo, a autora demonstra aspectos parecidos ao caso de Ribeirão Preto investigado neste trabalho, uma vez que a ausência de instituições formais para assistência à infância desvalida era um fator que assemelhava as duas cidades no período. Sofrendo Franca com o mesmo problema do abandono de crianças e consequente miséria, viu-se no instrumento da tutela e nos arranjos de trabalho de crianças a possibilidade de tratar o problema social trazido pela infância pobre e abandonada na cidade, mas também com a necessária substituição de mão de obra escrava para a execução de serviços. Explica David (1997, p. 121) que:

[...] o sistema judiciário, mediante a tutela e contrato de soldada, arregimentava
crianças pobres e as distribuía a particulares interessados em tutelá-las. Mais do que
um ato solidário, a tutela correspondia à necessidade e ao uso espoliativo da mão-de-
obra barata, submissa ou gratuita de menores abandonados.
Nesse sentido, é provável que a tutela, segundo regras do Juizado de Órfãos tenha sido
uma forma de legalização do trabalho compulsório infantil.

Assim, no caso de Franca e em outras localidades, conforme demonstram as pesquisas de outros autores supracitados, conclui-se que os tutelados e/ou contratados, principalmente os provindos das camadas mais baixas da população, permaneceram em frágeis condições de vida ao serem maltratados pelo judiciário, pelos tutores e pelos contratantes, ainda que estes dois últimos, principalmente, firmavam o compromisso de mantê-las sob seus cuidados e com acesso à educação. David (1997, p. 122) conclui que "[...] a criança abandonada estava inserida na problemática social, que criava e nutria o sistema". 
Azevedo (1995) explica que os espaços exclusivos dos juizados de órfãos foram concebidos com vistas a regular ações para controlar crianças desvalidas, uma vez que "passaram a dá-las a tutores ou alugá-las através do contrato de soldada. [...] o poder público e parte da sociedade, visando retirar os menores abandonados de circulação, incentivaram a construção de entidades assistenciais que pudessem recolhê-las" (AZEVEDO, 1995, p. 30). Ainda, a autora elucida que além de interferências para tratar a infância desvalida de modo institucionalizado, haviam as preocupações dos próprios juízes de órfãos em relação a pobreza da família da criança encaminhada, procurando realizar intervenções dentro dos próprios lares destas. Zero (2004, p. 44) entende que "penetrar no campo do Direito brasileiro, [...] no que se refere ao direito no século XIX, é embrenhar-se em [...] paradoxos. As relações de interesse estavam evidenciadas no embate jurídico que existia entre a defesa legítima da liberdade e o respeito à propriedade privada". Assim, eis a importância em se compreender a modificação social que levou ao fim da escravidão e a modificação econômica decorrente desta, levando à mudança do trabalho escravo ao livre remunerado, uma vez que com essas modificações na sociedade brasileira, a hegemonia das classes mais abastadas foi sendo, aos poucos, enfraquecida. Dado essa situação, pressupõe-se que o discurso jurídico acerca do encaminhamento de crianças desvalidas para a condição de tuteladas/contratadas foi um meio encontrado pelas classes mais abastadas que ainda permeavam o judiciário para controlar essa infância.

Alguns casos encontrados nos processos utilizados para o desenvolvimento desse trabalho mostram que os juízes da época recebiam solicitações de tutela ou contratação de soldada, denúncias de fuga de menores ao ser solicitada busca e apreensão destes, solicitações de remoção de tutela pelo pressuposto fato da não adequação da criança aos bons costumes, entre outros. Ainda, pressupõe-se que estes realizavam os despachos sem consultar a criança solicitada em questão para, ao menos, entender o que se passava no relacionamento entre esta e seu tutor/contratante. Imagina-se que o fato ocorrido transformado em processo esquivava-se da possibilidade de a criança narrar sua versão e, com isto, a situação desta era ocultada pelos que detinham poder de fala, utilizando-se delas da maneira que mais os convinham.

Um fator importante a ser relembrado e que já foi discutido anteriormente é de que, no Brasil, o contrato de soldada relacionava-se com resquícios do regime escravista recémsuperado. Em 1871, com a Lei do Ventre Livre (BRASIL, 1871), uma nova relação de trabalho entre escravos e senhores passou a se desenvolver e, com a abolição da escravidão em 1888, a soldada passa a ser uma forma para que as crianças filhas de escravos sobrevivessem e exercessem algum tipo de serviço remunerado. Porém, o contrato não trazia garantias de que 
uma possível remuneração fosse, de fato, realizada. Observa-se então que, mesmo livres, filhos e filhas de escravos foram, mais uma vez, inseridos em um regime de trabalho abusivo como recurso para preencher a falta de mão de obra escrava com a justificativa pelo judiciário e pela sociedade de educar essas crianças, uma vez que, por serem filhas de escravos, imaginava-se que estas não teriam condições de compreender as relações externas a condição de escravidão (ZERO, 2004).

Também muito importante em ser observado e considerado é como a contratação de soldada, principalmente de meninas negras, correlaciona-se com a associação da mulher negra ao trabalho doméstico a partir do século XIX. Lorena Féres da Silva Telles (2011), ao dissertar sobre as experiências de vida e do trabalho doméstico de mulheres escravas, libertas e descendentes livres em decorrência da transição do trabalho escravo para o livre remunerado na cidade de São Paulo ao final do século XIX, mostra que mulheres ainda muito pequenas já eram cooptadas ao trabalho doméstico na forma de contratação de soldada quando crianças, sendo levadas por suas condições socioeconômicas a permanecer em tal função, ainda que emancipadas de seus tutores/contratantes pelo advento da idade adulta. Também, verifica que, por vezes, algumas meninas iniciavam a vida do trabalho doméstico desde a tenra idade em uma determinada casa até a idade adulta sem o compromisso firmado pelas vias jurídicas, recebendo baixos ordenados ou então sem o recebimento de qualquer quantia pelo serviço prestado, entre outros abusos, e observando que:

\footnotetext{
$\mathrm{O}$ alto percentual de mulheres negras inscritas [nos livros de inscrições e de contratos de trabalho livre] indica que a expansão do mercado de trabalho não lhes significou ganhos significativos: o peso das relações escravistas patriarcais e seu habitual desapreço pelo trabalho manual desempenhado tradicionalmente pelas escravas, relegavam aquelas agentes da subsistência e suas ocupações desqualificadas a baixos salários e a condições de trabalho particularmente opressivas: alicerces da subsistência apagada no contexto da construção da hegemonia econômica e política da burguesia cafeeira. (TELLES, 2011, p. 125).
}

Assim como o contrato de soldada, mesmo que firmado juridicamente não traria garantia alguma de proteção, os autos de tutela também poderiam se tornar um problema na vida das crianças. Consideradas como incapazes na criação de suas crianças, muitas famílias perdiam o direito sobre estas e tinham seus filhas e filhos levados para a condição de tutelados e/ou contratados. Ainda que tivesse pai e/ou mãe, a criança poderia ser considerada como órfã se sua família não demonstrasse condições financeiras concretas para cuidá-la, como também condição moral de acordo com os valores da época. Já no caso específico da mãe, esta não tinha direito algum sobre seus filhos, pois como já explicado anteriormente, o pátrio poder cabia ao pai e era este que iria decidir acerca da vida das crianças. Caso não tivesse pai, a criança estaria 
à mercê de uma decisão judicial que a levaria para a tutela ou contratação. Para designar uma criança como órfã, bastava que seu pai fosse falecido (mesmo com sua mãe viva) ou que sua família fosse considerada desvalida. Casos que poderiam se configurar como abandono por parte do tutor/contratante, caso a criança não demonstrasse bom comportamento ou serviço, esta poderia ser oferecida a outro tutor/contratante. Pressupõe-se que abusos físicos e psicológicos também ocorriam - com certa frequência -, ainda que tais informações constassem de modo arbitrário nos processos, uma vez que, por vezes, eram justificados pelo comportamento da criança ofendida. A ganância dos adultos pode ser pressuposta em processos que envolviam possíveis disputas de heranças das crianças órfãs que eram levadas de modo enviesado à tutela, sendo que, por vezes, o solicitante ao cargo de tutor conhecia a criança, sua família e seus bens, como também teria contato com os próprios juízes e curadores de órfãos, sendo facilitado o deferimento de sua solicitação. Ainda, pressupõe-se uma possível falta de afetividade por parte dos tutores, tratando a criança como uma mera (e desvalorizada, quando a criança em questão era desvalida) mercadoria. Abandonadas, retiradas de suas famílias, trocadas e abusadas, essas crianças teriam muito a contar e, principalmente, explanar sua real vontade acerca de seu destino e sua vida.

Como retrata Bastos (2012), cuja pesquisa é sobre os autos de tutoria e contratos de órfãos da cidade de Bragança, também no interior do Estado de São Paulo, entre os anos de 1889 e 1927, seria possível localizar indícios de conflitos e tensões nos processos. A partir do que versavam juízes e curadores de órfãos, como também pelo próprio tutor/contratante no decorrer do exame dos processos selecionados para sua pesquisa, Bastos (2012) observa que este último, por vezes, realizava queixas ao judiciário sobre o processo e manutenção da contratação das crianças em questão, indicando que o trabalho prestado pela criança não estava de acordo com o que fora estabelecido pelo processo, como também situações de fuga da mesma e/ou a não entrega da criança contratada judicialmente pela família desta. Ainda, "as tensões que eram geradas pelo não pagamento das soldadas obrigatórias, chegando, algumas vezes, a alegar ter legitimado o órfão como seu filho" (BASTOS, 2012, p. 42).

No que se refere justificar as ações com vistas de retirar e recuperar essas crianças desvalidas, Bastos (2012) explica que a estigma acerca do ambiente no qual a família da dita criança desvalida crescera, por vezes, era utilizada como estratégia do próprio judiciário para a imposição da tutela/soldada, uma vez que "ao associar uma ideia negativa em termos da pobreza das famílias, [o judiciário] encontrou aí a legitimidade para garantir a retirada da criança e posterior tutoria” (BASTOS, 2012. p. 77). A referida autora busca identificar indícios sobre as relações de trabalho da época com a educação das crianças desvalidas, elucidando possíveis 
motivos que levaram ao surgimento e permanência das tutorias e contratos, conforme demonstrou a documentação pesquisada. Ainda, ao decorrer da pesquisa, indagações acerca da compreensão do sujeito "órfão" e seu contexto histórico no discurso do judiciário da época levantaram questões sobre o conceito de família, pobreza e educação dos filhos, tendo como pressuposto o controle social da época a fim de retirar crianças das ruas. Com isso, Bastos (2012) levanta um importante questionamento acerca do rumo tomando pelo judiciário ao tomar medidas de controle e vigilância sobre a via familiar de tais crianças, buscando entender a motivação em monitorar a estrutura familiar, tomando como justificativa o modelo proposto pela legislação vigente da época, como também a perspectiva da sociedade de enfrentamento à pobreza, considerando as possíveis influências de ordem social, política e econômica do país. Assim, pressupõe a autora que "os autos de tutoria e contrato de órfãos podem nos apontar para uma realidade contrária ao ideário iluminista, demonstrando que para muitas crianças e jovens pobres a única possibilidade era o trabalho" (BASTOS, 2012, p. 21).

Entende-se, por ora, que a preocupação acerca do tratamento da criança desvalida no recorte estabelecido por esse trabalho estaria ligada ao modelo moral da época, considerando as influências do campo jurídico, social, político e econômico, como também religioso, tomando como premissa a ideia de Marcílio (1998) já contemplada nesse trabalho. Salienta-se, também, que o desenvolvimento acerca do sentimento de infância e sobre as crianças, como explica Ariès (1981), inferiram de modo profícuo para o estabelecimento dos diferentes modos de tratamento de crianças, considerando a variabilidade de contexto em que estas se encontravam inseridas. Assim, tais premissas são importantes para se entender a questão intrínseca acerca da compreensão sobre a infância desvalida e como tal foi tratada e qualificada pelo judiciário ribeirão-pretano. 


\section{A INFÂNCIA SOB TUTELA}

O Poder Judiciário é exercido por operadores de Direito, os quais, acredita-se, têm a competência e prerrogativa para julgar algo ou alguém de acordo com o que estabelecem as leis e a constituição de um determinado Estado e território. Ainda, o judiciário é visto como uma instituição competente para lidar com problemas que possam surgir, por exemplo e especialmente, na esfera privada das famílias (RÊGO, 2014).

$\mathrm{O}$ ato de judicializar algo pode corresponder ao movimento de se levar este algo pela via jurídica, entrar com uma ação judicial para resolver determinada demanda, efetivar uma ação judicialmente e/ou adotar práticas do Poder Judiciário para lidar com determinada questão. Utilizado na atualidade, o termo judicialização conferiria, assim, embasamento jurídico para lidar com uma questão em específico. O processo de judicialização, acredita-se, pode ter surgido já mesmo no período da Idade Média, devido a reestruturação do Estado por novos atores e demandas sociais, os quais reconheciam na instância equivalente ao Poder Judiciário, como é conhecido atualmente, a competência para a consumação e defesa de seus direitos (RÊGO, 2014). Das possíveis causas para a estruturação e manutenção do processo de judicialização, Cristiane Rêgo (2014, p. 29) observa:

[...] a adoção do sistema democrático; o princípio da separação de poderes; a existência de uma carta constitucional reconhecedora de direitos e deveres; a possibilidade de recurso ao Judiciário por grupos de interesses e por grupos de oposição; a inefetividade das instituições majoritárias em impedir o envolvimento de instituições judiciais em certas disputas políticas; a percepção negativa da população acerca das instituições majoritárias com a consequente legitimação de instituições judiciais e a ocorrência de delegação de poderes de decisão das instituições majoritárias em favor de instituições judiciais.

Explicam também Débora Alves Maciel e Andrei Koerner (2002, p. 115) que:

A expressão recebe um sentido de processo social e político, quando é usada para se referir à expansão do âmbito qualitativo de atuação do sistema judicial, do caráter dos procedimentos de que dispõem [...]. A judicialização é tomada como um processo objetivo utilizado para defender propostas de mudança na organização do Judiciário ou na cultura jurídica, considerada defasada face às novas necessidades sociais.

A judicialização pode ser considerada, então, como uma disputa entre as esferas pública e privada, no momento em que o Estado, a partir de regulamentação (leis e normas), passa a participar de modo mais efetivo na esfera privada, devido a uma possível inoperância/incompetência administrativa averiguada.

No caso específico da judicialização da infância, o Estado passa a regular o comportamento das famílias, dos adultos que cuidam de suas crianças e destas próprias. 
Contudo, tal participação, por mais que seja feita dentro de uma possível legalidade, pode ocasionar conflitos e tensões entre família e Estado diante da hipótese de a segunda estigmatizar a primeira acerca de uma possível incompetência a fim de garantir o direito das crianças. Sobre o processo de judicialização da infância na atualidade, Flávia Cristina Silveira Lemos (2014, p. 26) sintetiza que tal:

\begin{abstract}
Implica em transformar um amplo campo de práticas no âmbito da proteção da infância em encomendas dirigidas ao Poder Judiciário diretamente como se este fosse a primeira e única instância responsável pelo cuidado desse segmento da população. Também há um segundo movimento de judicialização que está relacionado à invasão do Poder Judiciário em todas as esferas de nossas existências em nome da defesa, proteção e garantia de direitos de crianças e de adolescentes. Estamos falando de forças centrífugas e de forças centrípetas que operam a formação de um dispositivo de segurança e que criam paradoxos, tais como o de que a proteção integral deve ser realizada pela inflação jurídica e, portanto, apenas por meio da intensificação da lei, das penas e medidas judiciais aplicadas a todos os acontecimentos que dizem respeito ao atendimento de crianças e adolescentes. Outro paradoxo é o de que qualquer situação de ameaça e de violação deverá ser imediatamente levada ao Poder Judiciário ou aos equipamentos de normalização que estão nas adjacências do mesmo, articulando normas e leis.
\end{abstract}

Ao se pensar no caso específico de Ribeirão Preto, no que compete ao objetivo geral da pesquisa, compreende-se que a tentativa de resolução do problema da infância na cidade, principalmente a desvalida, possa ser considerada como um processo de judicialização desta infância. A exemplo da falta de locais específicos na cidade para cuidar de crianças consideradas em situação de risco, pelo abandono ou pela negligência familiar, estas teriam sido encaminhadas através do instrumento da tutela e/ou contrato de soldada para novos rearranjos familiares, a fim de sanar a incompetência tanto administrativa da cidade quanto da esfera privada da família ribeirão-pretana.

Fonseca (2007), ao estudar sobre o Instituto Disciplinar do Tatuapé - instituição criada em 1902 para colocar em prática a ações prescritas pelo Código Penal de 1890 no que se refere aos menores considerados transgressores da lei -, explica com primazia sobre a relação estabelecida entre os menores e o Poder Judiciário da época:

Pensar na construção do menor nos discursos é importante também para discutir dois problemas: o primeiro é não entender o menor apenas como figura jurídica, que somente veio a existir depois do Código de Menores de 1927; o segundo é superar a ideia de que somente após esse Código, o Estado passou a assumir a assistência pública aos menores. Quanto a essas duas questões, temos a considerar que, desde 1890, os menores vinham aparecendo em diplomas legais e que, até 1927, eles já são vistos de maneira diferenciada pelos legisladores, o que se consubstancia nas leis em vigor, referentes a essas personagens. O Código de Menores veio para consolidar uma tendência que já vinha se expressando, desde 1890. Também o Estado já destinava, ainda que tacitamente, investimentos na criação de instituições para a menoridade [...]. (FONSECA, 2007, p. 87). 
As investidas estatais para manter o controle social, principalmente, entre as camadas baixas, sendo estas consideradas como as de maiores riscos, fundamentava-se pela lógica de um encaminhamento "natural" de crianças em condição de abandono e pobreza para a ostentação do caos em meio a ordem, voltando-se especificamente para a criminalidade. Assim, conforme explica Foucault (1999), esta criança pobre e abandonada, por ter grande potencial de infratora, deveria ser contida através do disciplinamento e punição do sujeito, e não apenas a ação realizada. Assim, acredita-se que o movimento da judicialização da infância parta do princípio de conter crianças e jovens desvalidos que acabassem por seguir tal profecia marginalizadora. Ainda, especificamente acerca do disciplinamento, entende-se por Foucault (1999) que o disciplinamento do corpo - "corpos dóceis", assim chamado pelo autor - poderia ser considerado como artefato de contenção e sujeição do sujeito, o qual pode-se observação pelo uso da mão de obra infantil e jovem - nada muito diferente como, por exemplo, se pensado no caso do contrato de soldada -, uma vez que estes passariam a se tornar úteis ao aparelho do Estado.

Ademais, conforme explicam Jacques Donzelot (1986) e Jurandir Freire Costa (2004), o discurso burguês - consonante aos princípios de ordem, controle e vigilância - contribuíram para fomentar e dar razão às intervenções judiciais na vida das famílias. Donzelot (1986), ao apresentar a história social da família do século XVIII ao início do século XX, explica acerca da definição de "família", a qual foi construída pelas camadas burguesas do Antigo Regime, sendo estendida como ideal para outras classes. A família, com o auxílio do Estado Moderno, era vista como alvo principal dos princípios da organização social, atendendo e perpetuando a lógica do sistema econômico de produção capitalista que se instalara. Dentre tais tentativas de organização, o Estado utilizou de discursos médicos, filosóficos, professorais, filantrópicos, psicanalíticos e religiosos. Assim, o autor trata do "problema" híbrido trazido pela modernidade, entre o poder das altas camadas da população - com seus desejos e meios de controle - e os modos de resistência e busca pela libertação dos meios de controle e vigilância das camadas mais baixas. Para Donzelot (1986) a prática do judiciário no desenvolvimento de meios de controle social, para assim serem efetivas, deveria considerar o caráter educativo das ações de assistências prestadas aos menores para que não se corresse o risco de estigmatização dos sujeitos.

Especificamente no tratamento de menores pelo judiciário, Donzelot (1986) explica que o surgimento de profissões como de assistente sociais, educadores especializados e orientadores atuando entre os complexos jurídicos, educacionais e assistenciais foi umas das formas de intervenção encontradas para contornar os problemas dos menos favorecidos e vulneráveis. 
Assim, tais profissionais atuavam em uma linha dupla, na qual tratavam a chamada infância em perigo e a infância perigosa, visando mais por uma compreensão das situações do que o encaminhamento às sanções judiciárias. Contudo, ainda que tais intenções se mostrassem contrárias aos discursos de estigmatização já existentes, a dúvida acerca da efetividade de ações paliativas em conjunto às aptidões familiares na criação de suas crianças permaneceu e continuou a fomentar o encaminhamento da infância ao judiciário, sendo este considerado como meio mais eficaz para tratar o problema de desvio à ordem cometido pelos menores (DONZELOT, 1986).

Costa (2004) explica como o discurso médico auxiliou na estigmatização das camadas baixas, dando condições para que a intervenção judicial ocorresse tendo como base a crença de que o estabelecimento de hábitos adequados pelas crianças, da alimentação ao vestuário, seria determinante na constituição destas como adultos decentes. O pensamento médico da época tinha como tese a propensão para criminalidade de crianças encaminhas à tutela, uma vez que tal ação seria decorrente dos maus hábitos e pobreza de origem. Assim, a intervenção jurídica se fazia extremamente necessária, uma vez que pelo próprio e incontestável discurso médico da época, crianças que passavam pela experiência da tutela necessitavam de atenção especializada para que tivessem sua indisciplina contida, independentemente de como tal contenção ocorresse, seja pelo meio do rígido controle até a punição física (COSTA, 2004).

Por fim, observa-se que o instituto jurídico, já reconhecido pelos outros poderes como necessário e eficaz no tratamento da infância pobre, abandonada e marginalizada, tinha como força para seu estabelecimento e manutenção os discursos das camadas altas e o considerável discurso médico para agir de modo que assim fosse necessário. Sob uma lógica de que os fins justificavam os meios, o medo pelo futuro da infância desvalida nada mais era do que o medo da luta e resistência das camadas mais baixas da sociedade que poderiam destruir o sonho do moderno, do progresso e da ordem. 


\subsection{Do ato ao auto ${ }^{40}:$ o que os processos "contam" sobre a infância e o cotidiano ribeirão- pretano}

\subsubsection{A vez em que Honorina foi ouvida}

No dia 5 de junho de 1903, Hermenegildo da Silva Victorino dirigiu-se ao Juiz de Direito da Comarca de Ribeirão Preto para solicitar a retirada do cargo de tutora concedido à Gregoria Bomfim, viúva de seu irmão, Francisco da Silva Victorino, para a criação de Honorina da Silva Mattos, filha desta. Ao solicitar tal retirada, Hermenegildo a justificou pela falta de "procedimento moral por Direito necessário para o exercício desse cargo" ${ }^{41}$ da ex-cunhada, sendo essa justificativa provinda de depoimentos de algumas testemunhas. Com essa petição inicial, deu-se início a briga judicial acerca da tutela de Honorina entre seu tio, Hermenegildo, e sua mãe, Gregoria.

Para compor todo o cenário necessário ao andamento do processo, foram oferecidas por Hermenegildo as testemunhas Ennes Verdi, Raul Guião, Antonio de Almeida, Joaquim Pinto de Almeida, Manoel Vieira da Silva e Alfredo Condeixa para "justificar a irregularidade de conduta e incontinência pública escandalosa da suplicada Gregoria Bomfim, tutora de sua filha Honorina e viúva de Francisco da Silva Victorino"42. Ainda, para participarem da inquirição das testemunhas oferecidas por Hermenegildo foram chamados seu advogado, o Dr. João Braz de Oliveira Arruda, e o Dr. Mario de Almeida Pires, Curador Geral de Órfãos do referido período. Gregoria Bomfim, a suplicada, também fora intimada "para assistir a mesma inquirição e defender-se do alegado na mencionada petição inicial; sob as penas da lei"43. Assim, em 17 de junho de 1903, perante ao Dr. Eliseu Guilherme Christiano, Juiz de Direito da Comarca, ao escrivão Antonio Pereira da Silva Junior, que até então havia sido o responsável pela escrita dos documentos que constam nos autos, ao advogado de Hermenegildo e do Curador Geral de Órfãos, as testemunhas foram inquiridas.

Ennes Verdi, Manoel Vieira da Silva e Alfredo Condeixa, testemunhas intimadas para deporem a favor de Hermenegildo, juraram dizer a verdade na forma da lei e deram maiores detalhes para tentar comprovar o mal procedimento de Gregoria. Ennes Verdi relatou que a casa da suplicada era frequentada por cerca de oito pessoas com as quais ela mantinha "relações

\footnotetext{
${ }^{40}$ Expressão elaborada por Grinberg (2013, p. 128).

${ }^{41}$ APHRP, 1903, Fundo "Processos Antigos", Caixa 118-A, Processo 94.

${ }^{42}$ Ibidem.

${ }^{43}$ Ibidem.
} 
condenadas pela moral, que esse fato é muito conhecido em Villa Bomfim"44. Manoel Vieira da Silva também relatou que a casa de Gregoria era frequentada por alguns homens, sendo que estes se gabavam acerca das possíveis relações que mantinham com a mesma e que até mesmo o irmão da primeira testemunha era um destes. Ainda, disse que Gregoria o chamou para ir até sua casa a fim tratar sobre uma transação de mercadoria por ele ser negociante, pressupondo uma indireta de que ele poderia ser considerado como mais um dos homens que frequentavam sua casa, convite o qual ele recusou ${ }^{45}$. Alfredo Condeixa relatou maiores detalhes, entres eles alguns que poderiam confirmar a infidelidade da suplicada enquanto seu marido ainda estava vivo, dizendo que ela esteve "amigada com um português de quem teve um filho" 46 , que também esteve amigada com o irmão da primeira testemunha no tempo de morte do marido e que sua casa continuava a ser frequentada por muitos homens, tendo uma "vida de mulher perdida" ${ }^{47}$, fato muito conhecido em Villa Bomfim. Gregoria, ainda que tenha sido intimada para comparecer na inquirição, não consta como presente no documento, assim como Antonio de Almeida e Joaquim Pinto de Almeida. Já Raul Guião não havia sido encontrado e por isso não foi intimado.

Realizada a inquirição e após o exame realizado pelo Curador Geral de Órfãos, eis que sua decisão sobre o pedido de Hermenegildo foi revelada em documento:

\footnotetext{
Examinados os presentes autos, opino pela denegação do pedido.

Gregoria Bomfim não é simples tutora de sua filha menor, como quer o requerente, tem pátrio poder sobre ella (artigo 94 do Decreto de 24 de Janeiro de 1890, Clovis Bevilaqua, D da Familia $\$ 76 \mathrm{n}^{\circ}$ 1) e do seu exercicio só poderá ser privada - per sentença passada em julgado em aç̧ão competente nos casos em que pode ser o pae compelido a emancipar o filho - (Lafayette $\$ 119 \mathrm{n}^{\circ} \mathrm{IX}$ ), e não por meio da presente acção summarissima, que absolutamente não tem aplicação ao caso.

Rib. Preto, 19 junho 1903

O Curador Geral Mario de Almeida Pires ${ }^{48}$.
}

Ao opinar pela denegação do pedido de retirar Gregoria do cargo de tutora de sua filha, o Curador Geral de Órfãos utilizou como argumento o fato dela deter sob forma legítima o pátrio poder sobre a menor Honorina. Apoiando-se no artigo 94 do Decreto $n^{o}$. 181, de 24 de janeiro de 1890 (BRASIL, 1890), o qual promulga sobre o casamento civil, o Curador Geral de Órfãos inferiu sua decisão sobre o fato de que “[...] si o conjuge fallecido for o marido, e a mulher não for binuba, esta lhe succederá nos seus direitos sobre a pessoa e os bens dos filhos

\footnotetext{
${ }^{44}$ Ibidem.

${ }^{45}$ Ibidem.

${ }^{46}$ APHRP, 1903, Fundo "Processos Antigos", Caixa 118-A, Processo 94.

${ }^{47}$ Ibidem.

${ }^{48}$ Ibidem.
} 
menores, emquanto se conservar viuva [...]". No caso, Gregoria, ao não se casar novamente até então, não se tornou binuba e, assim, manteve o direito de ser tutora de sua filha.

Hermenegildo, insatisfeito com a decisão tomada pelo Curador Geral de Órfãos, em 19 de junho de 1903, contrapôs os argumentos colocados por este, alegando que as leis citadas na petição inicial, entre elas o Direitos de Família, escrito por Lafayette Rodrigues Pereira (1869), como também as Primeiras Linhas sobre o Processo Orphanologico, escrito por José Pereira de Carvalho, explicavam que não havia distinção entre o tutor com pátrio poder e sem pátrio poder. Com isto, enfatizou que a suplicada em questão, mesmo sendo tutora de sua filha, não deveria deter o pátrio poder sobre mesma, uma vez que não dispunha de recursos morais necessários para o cargo, já que "abandonava” sua filha ${ }^{49}$. Considerando a influência do direito romano na formulação das leis do Império Português vigentes no período, as Ordenações Filipinas, Hermenegildo alega que, ao não tomar como verdadeiro seu pedido de retirada de tutela, o Curador Geral de Órfãos “torna-se cúmplice da depravação de uma criança, [...] é pior que matá-la, é o que não é lícito do Juízo tutelar dos Órfãos, por promoção do Curador a quem incumbe zelar os interesses dos menores" ${ }^{\prime 50}$, denunciando que o Curador Geral de Órfãos talvez não tivesse conhecimento sobre a própria doutrina jurídica em que estava inserido. Por fim, no mesmo dia, os autos foram considerados conclusos pelo Juiz de Direito da Comarca, o Dr. Eliseu Guilherme Christiano.

Contudo, apenas em 22 de junho de 1904, um ano depois da abertura do processo, o Juiz de Direito da Comarca julgou como "nulo todo o processado visto não ter sido a suplicada Gregoria Bomfim citada para o fim constante da petição de f. 2, pois no mandado de f. 5 não se contém, ao menos em resumo, o alegado na referida petição" ${ }^{51}$. Um possível motivo para compreender a extensão de tempo desde a abertura do processo até o último pronunciamento do Juiz de Direito da Comarca ainda é uma lacuna a ser preenchida. Porém, também constam nos autos que, após isto, Hermenegildo entrou com um termo de apelação, em 4 de julho de 1904, no qual solicitou que sua petição inicial fosse considerada e que o processo continuasse em andamento ${ }^{52}$. A apelação foi despachada, assinada pelo Juiz de Direito da Comarca e encaminhada às instâncias cabíveis.

Esses autos até então descritos foram encontrados na Caixa 118-A. Entretanto, a história de Hermenegildo, Gregoria e Honorina prosseguiu em outros autos que se encontram na Caixa

\footnotetext{
${ }^{49}$ APHRP, 1903, Fundo "Processos Antigos", Caixa 118-A, Processo 94.

${ }^{50}$ Ibidem.

${ }^{51}$ Ibidem.

${ }^{52}$ Ibidem.
} 
64-A. Nesses outros autos, com a petição inicial elaborada no dia 13 de julho de 1904, Hermenegildo realizou novamente o pedido de retirada de Gregoria como tutora de sua filha Honorina. Contudo, havia um novo cenário descrito Hermenegildo e o qual se tornou seu argumento principal:

Exmo. Sr. Dr. Juiz de Direito da vara de Orphãos

Diz Hermenegildo da Silva Victorino que, tendo falecido o seo irmão Francisco da Silva Victorino, deixou uma filha menor, de nome Honorina, sob o poder da viva Gregoria Bomfim. Como tenha ésta passado a segundas núpcias, conforme se vê da certidão ora oferecida, vem o suplicante requerer a V.E. se digne de o nomear tutor da mesma menor visto haverem cessado os direitos que competião a Gregoria Bomfim sobre a pessoa e os bens da filha.

P. deferimento

E. R. M.

Ribeirão Preto, 13 de julho de 1904

Hermenegildo da Silva Victorino ${ }^{53}$.

Valendo-se do discurso jurídico vigente no período, no qual questões inerentes à tutela e/ou administração de bens herdados por menores estavam fundamentados pelo pátrio poder, Gregoria, ao casar-se novamente, tornou-se binuba, perdendo assim, o direito à tutela da filha Honorina, segundo a continuação do já citado artigo 94 do Decreto $n^{o}$. 181, de 24 de janeiro de 1890: “[...] Si, porém, for binuba, ou estiver separada do marido por culpa sua, não será admittida a administrar os bens delles, nem como tutora ou curadora" (BRASIL, 1890). Contudo, Gregoria e seu novo marido, Diogo Brunno, rebateram tais argumentos também utilizando a lei vigente no período, tentando elucidar a falta de capacidade de Hermenegildo por este ser "desassisado", algo relativo a um sujeito sem juízo, desatinado. Assim, tomaram como principal argumento as Ordenações Filipinas e sua influência no documento de José Pereira de Carvalho, Primeiras Linhas sobre o Processo Orphanologico, no qual consta na nota 246:

Mal poderião administrar os bens alheios aquelles que são inhabeis para administrarem os seus, e por isso com razão excluio a lei semelhantes pesssoas de poderem ser tutores: Ord. do liv. $4^{\circ}$, tit. $102, \S 1^{\circ}$. São igualados aos sandeus e desassizados os furiosos, os prodigos, os desmemoriados, os estupidos e outros semelhantes: Ord. do liv. $4^{\circ}$, tit. 103. (CARVALHO, 1880, p. 67).

Gregoria e Diogo afirmaram nos autos que Hermenegildo era inabilitado para o cargo de tutor de Honorina, pois seria um "negociante falido, tendo proposto pagar vinte por cento aos credores, o que foi aceito por estes, sendo homologada a concordata judicialmente, e não tendo o falido cumprido o que ele mesmo propôs [...]"54. Também seria inabilitado por ser

\footnotetext{
${ }^{53}$ APHRP, 1904, Fundo "Processos Antigos", Caixa 64-A, Processo 98, grifo nosso.

${ }^{54}$ Ibidem.
} 
"legalmente inimigo da menor, pois esta, como única herdeira de seu finado pai Francisco da Silva Victorino, é do mesmo Hermenegildo credora da quantia de 3:383\$365, como se vê da certidão inclusa" ${ }^{55}$, argumento que também tem como base o discurso jurídico encontrado no Livro IV das Ordenações Filipinas, Título CII, §1º, nota 4, o qual afirma:

Também se acha no caso do inimigo do Orphão, para excluir da Tutoria:

1. O credor ou devedor do Orphão.

2. O que com mesmo Orphão tem demanda, pois como os primeiros, são suspeitos de parcialidade e infidelidade.

3. Os que tem bens em comum com o pupillo, ou ao mesmo pupillo pertencentes. (ALMEIDA, 1870b, p. 996).

Ainda, "também porque é inimigo da suplicante, mãe da menor Honorina e porque voluntariamente se ofereceu (notas 250 e 253 ao $\$ 129,2^{\circ}$ e $5^{\circ}$ da cit. obra de Pereira de Carvalho). [...] Relativamente ao oferecimento voluntário, não se argumente com a pobreza da

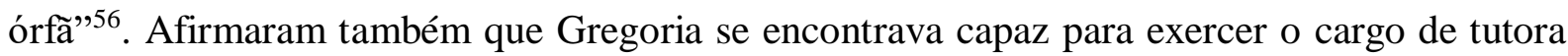
da filha por disponibilizar de recursos financeiros para "concorrer com as quantias necessárias para a sua manutenção e educação" ${ }^{\text {57 }}$. Finalizaram o pedido comentando que até poderiam sugerir a nomeação do padrasto da Honorina para ser o tutor, mas que não o fariam por acreditar que a argumentação apresentada já seria o bastante. Defendendo-se das acusações sofridas, Hermenegildo alegou ao Juiz de Direito da Comarca que o mesmo poderia ter dificuldades para encontrar alguém mais apto ao cargo de tutor da menor Honorina, uma vez que os habitantes da cidade de Ribeirão Preto encontravam-se em sua mesma difícil condição econômica.

Meses se passaram entre argumentos, denúncias e defesas entre Hermenegildo e Gregoria. Em 26 de abril de 1905, Gregoria retornou ao Juiz de Direito da Comarca com um novo pedido de restabelecimento do seu cargo de tutora da filha e é somente a partir deste seu relato que podemos afirmar que Honorina já se encontrava sob os cuidados de seu tio Hermenegildo:

Exmo. Sr. Dr. Juiz de Direito

Por seu advogado infra assignado, conforme procuração juncta, diz e requer D. Gregoria Bomfim o seguinte:

Por morte de seu primeiro marido, achava-se a menor Honorina, filha da supplicante, em poder de Hermenegildo da Silva Victorino, tio da mesma, residente em Cravinhos; casando-se a supplicante em segundas núpcias com Diogo Brunno, recusou-se o mesmo Hermenegildo a entregar-lhe a sua referida filha, sob protesto de que havia a supplicante pelo casamento realizado, perdido o direito de pátrio poder sobre ella e requereu a tutela desta, como tudo consta em juízo, não tendo ultimado o processo respectivo mas continuando a mesma em poder do seu já referido tio, que se obstina em não consentir que ella volte para a companhia da supplicante,

\footnotetext{
55 Ibidem.

${ }^{56}$ APHRP, 1904, Fundo "Processos Antigos", Caixa 64-A, Processo 98.

${ }^{57}$ Ibidem.
} 
alegando mesmo para impedil-o, a pedir a intervenção da polícia e a empregar meios violentos. Tendo enviuvado ultimamente a supplicante, como prova com a certidão de óbito juncta, e assim readquirido em sua plenitude o pátrio poder sobre a pessoa e bens de sua filha, e esta para requerer a V. Ex. a apprehensão da mesma e sua entrega a supplicante.

Pede, pois, que sirva-se V. Ex. ordenar que junctando-se esta aos autos do processo da tutela em tempo requerida, espeça se o competente mandado de apprehensão, com as formalidades e sob as penas legais.

E. deferimento

Ribeirão Preto, 26 de Abril - 1905

Renato $\operatorname{Jardim}^{58}$.

Contudo, é somente em 10 de outubro de 1911, conforme consta em documento, que Hermenegildo entrou com um pedido ao Juiz de Direito da Comarca para não mais ser o tutor de sua sobrinha Honorina, já púbere, solicitando a nomeação de Julio Pedro Pontes como tutor da mesma ${ }^{59}$. Ainda, em 21 de outubro de 1911, legitimando esse acontecimento, a própria Honorina foi chamada para depor acerca de sua situação - algo que poderia ser considerado novo, uma vez que no andamento de processos semelhantes a este, o sujeito que mais se encontrava afetado com as decisões tomadas pelo judiciário da época não costumava ser ouvido: a criança a ser tutelada.

Eis a declaração de Honorina da Silva Mattos, já com 16 anos:

Termo de declaração da menor púbere Honorina

Aos vinte um dias do mez de Outubro de mil novecentos e onze, nesta cidade do Ribeirão Preto, em cartorio, perante o M. Juiz de Direito da Comarca - Doutor Eliseu Guilherme Christiano, comigo escrivão de seu cargo, infra nomeado - e o Doutor Mario de Almeida Pires, curador geral de orphão compareceu a menor Honorina da Silva Mattos, de dezesseis anos, filha de Francisco da Silva Victorino, já falecido e Gregoria Bomfim; e o M. Juiz lhe faz as perguntas - que assim respondeu: - que desde a idade de um anno tem vivido em companhia de seu tio Hermenegildo da Silva Victorino, por quem foi creada, sendo que, mesmo em vida de seu pae, já ella declarante estava em companhia de seu dito tio; que por este é que tem sido creada, recebendo á sua custa alimentação, vestuário, educação e não lhe consta que até hoje sua mãe - Gregoria Bomfim tenha concorrido com dinheiro para sua manutenção; disse finalmente que é de sua espontanea vontade continuar em companhia de seu referido tio em cuja casa tem recebido carinhoso tratamento e uma vez que o mesmo não deseja ser seu tutor, como já manifestou, é de seu agrado que esse cargo seja exercido por Julio Pedro Pontes, que é casado com uma sua tia e em cuja casa a declarante tem passado temporadas por mais de uma vez - quando seu tio Hermenegildo esta na Fazenda e ali tem recebido sempre o mesmo carinhoso trato - que lhe é dispensado em casa deste ultimo. Dada a palavra ao Dr. Curador Geral, por elle nada foi perguntado. E lido e achado conforme - assigna com o M. Juiz e Dr. Curador de Geral. Eu Antonio Pereira Silva Junior, escrivão escrevi.

Eliseu Guilherme Christiano

Honorina da Silva Mattos

Mario de Almeida Pires ${ }^{60}$.

\footnotetext{
${ }^{58}$ Ibidem, grifo nosso.

59 APHRP, 1904, Fundo "Processos Antigos", Caixa 64-A, Processo 98.

${ }^{60}$ Ibidem, grifo nosso.
} 
Em 26 de outubro de 1911, 8 anos e 4 meses depois da primeira petição nos autos que tramitaram no judiciário acerca da tutela de Honorina, o Curador Geral de Órfãos, Dr. Mario de Almeida Pires, não se opôs pela alteração do cargo de tutor de Honorina para Julio Pedro Pontes, conforme pedido pelo próprio Hermenegildo e também pela menor. Assim, o Juiz de Direito da Comarca, Dr. Eliseu Guilherme Christiano, nomeou Julio como novo tutor, em 27 de outubro de $1911^{61}$, pontuando o encerramento do processo.

Ainda que encerrados os autos, nos deparamos com lacunas no decorrer dos mesmos, como, por exemplo, o tempo de duração e a distância entre alguns requerimentos que foram realizados com intervalos de anos. Confirmado apenas pela declaração de Honorina que ela já se encontrava sob os cuidados do tio desde a tenra idade, pressupõe-se que a menina não teve tempo algum de convivência com a mãe, o que poderia agravar a situação de Gregoria no que se refere a sua não possibilidade de criar a filha. Assim, deve-se atentar para o discurso de Honorina pela sua preferência em ficar com seu tio, pois a mesma poderia ter sido enviesada a dar tal declaração, uma vez que não teve, ao menos, a possibilidade de criar vínculos com sua mãe e conhecer os reais motivos que levaram a disputa de sua guarda. Ainda, o longo tempo decorrido da abertura do processo até sua finalização pela declaração da menina, o qual durou cerca de oito anos, pressupõe-se a prática arbitrária do judiciário ao lidar com questões de requerimento de tutela quando a suplicante seria a mãe, pautados pela doutrina jurídica do pátrio poder. Ainda e não mesmo importante, torna-se profícuo observar que o caso supracitado foi desenvolvido com o embasamento jurídico da época, o qual tanto Hermenegildo quanto Gregoria dispuseram dos aparatos legais vigentes para fomentarem suas justificativas em seus requerimentos, indicando que a situação abrangia sujeitos de classes mais abastadas, os quais detinham de poder financeiro para a contratação de advogado ou então com conhecimento necessário sobre a doutrina jurídica para realizar sua solicitação com uma possível certeza de razão.

\subsubsection{O dia em que Victalina acreditou ser livre}

Em 2 de dezembro de 1892, no cartório do $1^{\circ}$ Oficio de Ribeirão Preto, mais um processo judicial era produzido. O escrivão Jose Victorino de Sampaio Netto, no exercício de sua profissão, dava início ao auto solicitado pelo Tenente Jose da Fonseca Nogueira, no qual requeria a expedição de um mandado de busca e apreensão da menor Victalina. Tendo sido a

\footnotetext{
${ }^{61}$ Ibidem.
} 
menina criada pelo Tenente Nogueira desde a tenra idade, conforme fato narrado por este, a menor Victalina, órfã de pai e mãe, teria "sahido de sua casa sem motivo que justifique tal procedimento, achando-se presentemente em casa do Engenheiro Dr. Alcantara" ${ }^{\natural 2}$.

Neste mesmo processo foi incluído uma cópia do termo de contratação de Victalina e seu irmão Emerenciano pelo Tenente Nogueira, a saber:

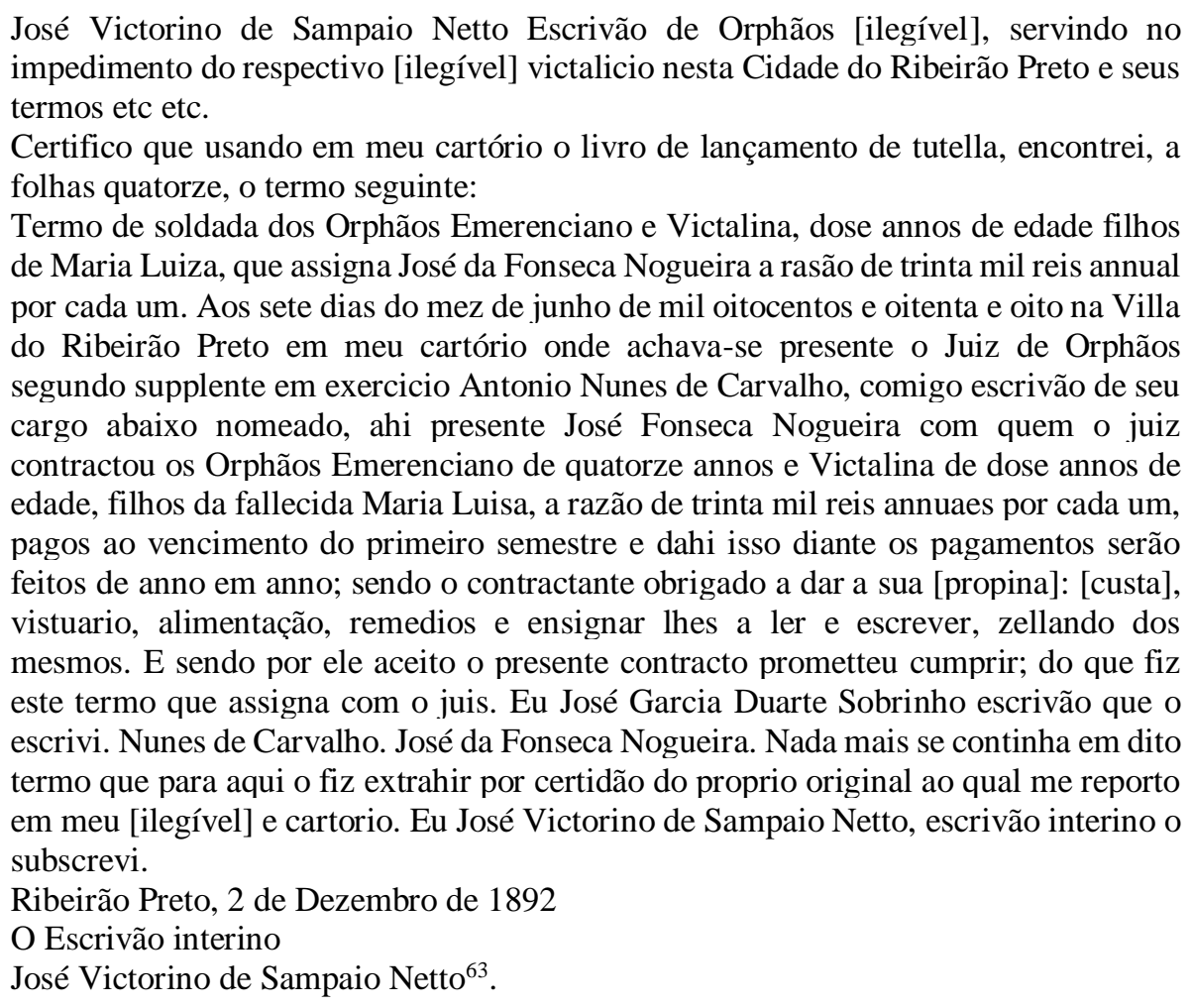

Assim, entende-se e comprovava-se a guarda de Victalina por meio do contrato de soldada, e não por tutela, conforme havia sido informado na petição inicial, a qual encontravase sob poder do Tenente Nogueira desde ano de 1888.

Contudo, mal poderia o Tenente Nogueira imaginar que a mesma Victalina, tomada pela certeza de sua razão e reunida de coragem, também procuraria a mesma justiça para fazer entender a realidade da situação descrita por seu contratante, ou no caso e conforme seu depoimento, ex-contratante:

$\mathrm{Ex}^{\circ}$. Sr. Dr. Juiz de Direito

Diz Victalina Custodio, natural do Rio de Janeiro, com 18 annos de idade, que estando, de [ilegível] data, em casa de José Nogueira, a quem tem servido como criada, acontece que não pôde por mais tempo supportar os constantes maus tratos alli recebidos, motivo esse que a levou retirar-se d'aquella casa, empregando-se, dias depois em casa do Sr. Dr. F. X. Alcantara.

A supplicante supõe que é livre, se é que a lei de 1888 se pode estender a ella, que, desprotegida, orphã, tem supportado [ilegível] martyro com os [ilegível] castigos

\footnotetext{
62 APHRP, 1892, Fundo "Processos Antigos", Caixa 82-A, Processo 58.

${ }^{63}$ APHRP, 1892, Fundo "Processos Antigos", Caixa 82-A, Processo 58.
} 
recebidos em casa seus senhores, e foi, segura d'essa liberdade, que abandonou aquella casa, contractando-se em outro, onde pela primeira vez vae ganhar salario, sendo certo que nem dinheiro nem roupas recebia anteriormente.

Hoje, seus ex-senhores foram procurar a supplicante em casa de seus novos patrões, tentando leval-a consigo, e ameaçando-a em vista de sua recusa, de reclamar a intervenção do Juiz.

A supplicante, portanto, apressa-se a ir pedir a proteção da lei contra a tyrannia a que a querem sujeitar. Escrava, voltará resignada a receber os caricias constantes do chicote, se, porem, a julgarem livre, quer ficar onde ora se acha ou onde [ilegível] lhe convenha estar.

Seu ex-senhor não [ilegível] que [ilegível] a supplicante com pancadaria perenne, e, para garantir o seu depotismo, alega tutella em pessôa maior. A elle incumbe provar a identidade da supplicante em relação a documentos que por ventura apresente.

A supplicante vem collocar a sua liberdade sob protecção honrada e [ilegível] de V. Excia.

Ribeirão Preto, 2 de Dezembro de 1892

Ao rogo de Victalina Custodio

Macario Campos J. ${ }^{64}$.

Victalina, apesar das ameaças feitas por seus antigos patrões, recorreu ao judiciário para manifestar a realidade em que vivia: a mesma não era tutelada pelo Tenente Nogueira, mas sim contratada por este para servir em sua casa. Victalina, por se considerar maior de idade, acreditou que o contrato, firmado quando esta ainda era criança, havia perdido sua validade, podendo assim, poderia libertar-se dos constantes castigos que indicou sofrer, mesmo tendo o Tenente Nogueira firmado no contrato de soldada supracitado o compromisso em zelar por ela e por seu irmão.

Por citar "a lei de 1888 " e se tal "se pode estender a ella", como também o fato em se declarar como escrava e que voltaria a casa do Tenente Nogueira "resignada a receber os caricias constantes do chicote" $" 65$, Victalina, possivelmente, demonstrou compreender acerca das mudanças legislativas no que se refere a abolição da escravatura no Brasil. Ao explicitar que "seus ex-senhores foram procurar a supplicante em casa de seus novos patrões, tentando leval-a consigo, e ameaçando-a em vista de sua recusa, de reclamar a intervenção do Juiz", observa-se sua busca pelo judiciário a fim de elucidar questões referentes a não subordinação da infância pobre e negra, a qual acreditava que deveria ocorrer naturalmente de acordo padrões de ordem que vinham se estabelecendo.

Acredita-se que o processo tenha sido finalizado em pouco tempo e deferido a favor de Victalina, uma vez que as poucas páginas seguintes encontram-se organizadas de modo confuso e sem nada conclusivo. Contudo, assim como no caso de Honorina, Victalina pode prestar seu depoimento e, possivelmente, o teve considerado na decisão final dada pelo Juiz de Direito da cidade. Importante considerar as possíveis diferenças entre as duas meninas: Honorina teve sua

\footnotetext{
${ }^{64}$ APHRP, 1892, Fundo "Processos Antigos", Caixa 82-A, Processo 58.

${ }^{65}$ Ibidem.
} 
tutela requerida tendo como motivação principal questões referentes ao que herdara de seu pai, sendo sua mãe viva e buscando juridicamente a devolução de sua filha para seus cuidados e, possivelmente, sendo de cor branca, considerando tal premissa acerca da cor padrão (BRIOSCHI, 1995); Victalina teve sua apreensão requerida, uma vez que havia abandonado a casa onde vivia e servia, sofrendo possíveis violências físicas e usando como argumento principal para tal ação o fato de se considerar livre, considerando a promulgação da Lei Áurea (BRASIL, 1888), uma vez que informou ser escrava, ou seja, muito possivelmente da cor negra, na casa de seu ex-contratante. Torna-se possível também que Victalina possa ter realizado uma associação entre o trabalho pelo qual foi contratada e como era tratada, ao informar que não havia recibido nenhum cuidado e muito menos o pagamento firmado juridicamente pelo Tenente Nogueira. Teria Victalina observado que o instrumento do contrato de soldada visava o prolongamento da escravidão de crianças negras, mesmo que livres após a promulgação da Lei do Ventre Livre (BRASIL, 1871)? Tal hipótese torna-se possível ao considerar a idade de Victalina em seu depoimento: tendo 18 anos no ano de 1892, esta teria nascido no ano de 1874 , três anos após a determinação de que crianças nascidas em ventre escravo seriam, a partir de então, livres. O caso de Victalina demonstra que além da busca pela intervenção jurídica, no que se refere ao controle e vigilância da infância desvalida, esta infância também demonstrava sinais de luta e resistência para manter-se livre e longe das amarras de tutores e contratantes abusivos.

\subsubsection{O caso de "amor" que se tornou caso de polícia}

Estaria Maria aguardando a chegada de Arthur? Estaria Arthur indo ao encontro de Maria? Ainda que não seja possível ter certeza sobre como tudo ocorreu, teria sido a partir do dia 20 de novembro de 1910 que os dois, finalmente, ficaram juntos. Maria teria deixado para trás seu pai e a fazenda São Luís e rumado, junto ao italiano Arthur, para a fazenda Santa Olympia onde ele residia. Acredita-se que, possivelmente, o que os mantinha separados era a idade: ele maior e ela menor, com 18 anos. Teria sido então a fuga a única opção? Maria teria sido pega de surpresa e raptada por Arthur? O casal, contudo, teria permanecido junto e sem qualquer impedimento durante o período de uma semana, pois o seu suposto amor viria a se tornar caso de polícia:

Ribeirão Preto, 27 de novembro de 1910

Exmo. Sr. Dr. Eliseu Guilherme Christiano, Dr. Juiz de Direito desta Comarca Estando presos nesta cadeia - Arthur Dario, italiano, maior e Maria Carmissa, brasileira, menor, que declara ter 18 annos, vindos da fasenda Santa Olympia, deste 
municipio, por ter o primeiro, residente em dita fazenda, raptado a $2^{\mathrm{a}}$, que, então (no dia 20 do corrente) morava com seu pae José Carmissa, na fazenda São Luiz, [ilegível] desse municipio; e, como José Carmissa tenha se mudado deste dito municipio para logar incerto, pois Maria dis [ilegível] constar que seu pae mudou-se para Araraquara, depois que ella se evadiu do lar paterno; assim como [ilegível] se casar para evitar a inquirição [ilegível], mas, como para isso depende do consentimento paterno, - por este venho requisitar de V. Excia. as respectivas providencias para que seja [ilegível] o [acludido] consentimento.

Saude e fraternidade.

O delegado de policia Joaquim [Machado da Teixeira $]^{66}$.

O delegado Joaquim, possivelmente se preocupando em manter a situação sob controle, teria considerado por dar a opção do matrimônio ao casal, pois, de um jeito ou de outro, pelo amor ou pela retratação, o melhor seria fazer com que Arthur se casasse com Maria para que esta, possivelmente, não caísse em desgraça social. Maria, assim, teria sua honra conservada em público. Maria, de menor raptada e ofendida, passaria a ser mais uma mulher honrada e casada da sociedade ribeirão-pretana. Para isso, seria necessário o consentimento de José, pai de Maria, mas, ao que parecia, após se ver só em sua fazenda, este teria partido para a cidade de Araraquara. Como proceder para consertar os estragos causados pela paixão dos jovens?

Porém, teria sido em 2 de dezembro de 1910 que a solução se apresentou:

Emxo. Sr. Dr. Juiz de Direito

Em vista do que consta do incluso officio, apresentado a esta Curadoria por despacho de V. Exa., por [ilegível] que se deve dar á menor Maria Carmissa um tutor, o que ora [ilegível] a V. Exa. indicando para servir esse cargo o cidadão Isaac Rodrigues de Oliveira, empregado publico, residente n'esta cidade.

Com o incluso officio.

Ribeirão Preto, 2, Dezembro, 1910

Mario de Almeida Pires

Curador Geral ${ }^{67}$.

Procurando solucionar a situação, acredita-se o delegado Joaquim teria solicitado que o Juiz, Dr. Eliseu Guilherme Christiano, tomasse alguma providência acerca da necessidade em se realizar o matrimônio entre Maria e Arthur, mas sem indicar quais medidas tomar para encontrar o pai da menina para dar o consentimento. Não se sabe ao certo como, quando e quem procurou a Curadoria de Órfãos, mas é certo que tal ação foi acertada: o Curador Geral de Órfãos, Mario de Almeida Pires, observando a complexidade da situação, teria indicado que o funcionário público Issac Rodrigues de Oliveira tomasse o cargo de tutor de Maria para que, por fim, esta pudesse se unir com Arthur pelos laços matrimoniais. Se Maria e Arthur foram felizes para sempre não é possível saber. Contudo, todos as autoridades envolvidas no caso, o delegado Joaquim, o Juiz, Dr. Eliseu Guilherme Christiano, e o Curador Geral de Órfãos, Mario

\footnotetext{
${ }^{66}$ APHRP, Fundo "Processos Antigos", Caixa 162-A, Processo 136, grifo nosso.

${ }^{67}$ APHRP, Fundo "Processos Antigos", Caixa 162-A, Processo 136.
} 
de Almeida Pires, poderiam ficar tranquilos: mais uma honra feminina teria sido restabelecida em Ribeirão Preto.

O casamento de Maria e Arthur, possivelmente, foi apenas um dos vários ocorridos na cidade através do "auxílio" policial, conforme também pode ser verificado nas fontes jornalísticas utilizadas anteriormente. Com vistas a consertar o dito comportamento irregular de muitas mulheres, encontrou-se na possibilidade do matrimônio a reparação do rapto - e possível defloramento -, juntando-se uma menor ao seu interesse amoroso (ou algoz). A busca pela regularização do comportamento dos vulneráveis - mulheres e crianças -, se atenuava quando esta mulher era uma criança, uma menor.

Não há a intenção neste trabalho em realizar um aprofundamento acerca de questões de gênero e sexualidade, contudo é necessário compreender o que a lei do referido período determinava acerca da situação de defloramento, termo comum na época estudada. De acordo com o Livro V das Ordenações Filipinas, Título XXIII, "Do que dorme com mulher virgem, ou viuva honesta per sua vontade" (ALMEIDA, 1870c), este deveria reparar seu erro casandose com a mesma, uma vez "se ella quizer, e se fôr convinhavel, e de condição para com ella casar", como também pagar-lhe um dote, caso não quisesse o casamento. Contudo, apenas no caso do homem não possuir condições financeiras para a realização do casamento ou pagamento do dote, este seria encaminhado à pena de degredo. Observa-se que o tratamento de estupro de vulnerável pelo judiciário da época apenas se consistia em uma "reparação de erro" pelo casamento, o que pode levar a pressupor e fomentar o ideal da mulher casada como uma mulher digna. Ainda, observa-se a intervenção não apenas do judiciário como também da polícia no encaminhamento da menina à tutela, mesmo que na condição de ad hoc, apenas para que esta tivesse um responsável legal que pudesse autorizar o matrimônio.

Observa-se e pressupõe-se que a interferência de delegados, no que se refere às solicitações de tutela, que tais encaminhamentos visavam o controle da população não apenas pelo judiciário, mas também com o aparato legal da polícia. A tutela, por vezes, tornava-se caso de polícia ao se observar cenários que apresentavam um comportamento extremamente inadequado, principalmente se este envolvesse as meninas. A imposição do casamento diante a um possível estupro de vulnerável demonstra, ainda mais, o quanto essa intervenção jurídica buscava controlar a população. 


\subsubsection{A tutela dignifica o homem}

Antonio d'Andrade teria sido um bom homem. Se não, no mínimo tentou ser. Afinal, o fato de abrigar quatro órfãos em sua morada, alimentando-os e educando-os, poderia ser considerado como um ato de bondade. João, Joaquim, Francisco e Guilhermina deveriam ser gratos à justiça divina, uma vez que tal nobre homem teria os considerado como se fossem seus próprios filhos. Contudo, Antonio também sabia que precisava informar à justiça dos homens acerca de seu possível ato de bondade e assim o fez:

Exmo. Ilmo. Dr. Juiz de Direito da Comarca de Ribeirão Preto

Diz Antonio d'Andrade, residente a Estação Velha n'esta cidade que tendo em sua companhia quatro crianças orphãs de pae e mae, de nacionalidade portuguesa, e todos menores de 12 annos, de nomes João, Joaquim, Francisco e Guilhermina, requer que Va. Exa. se digne de, ouvido o Dr. Curador Geral, nomear o supplicante para exercer o cargo de tutor dos referidos menores, visto tel-os creado, desde muito pequenos como filhos e desejar conserval-os em sua companhia.

N'estes termos

Pede deferimento

E. R. M.el.

Ribeirão Preto 2 de Fevereiro de 1903

Ao rogo de Antonio de Andrade que não escreve

A. Vianna Pinto de Souza ${ }^{68}$.

João, Joaquim, Francisco e Guilhermina, crianças órfãs de pai e mãe e todas menores de 12 anos teriam, por fim, continuado a permanecer na companhia de Antonio d'Andrade, o qual continuaria a zelar por estes como se fossem de seu próprio sangue.

Antonio Cabral Muniz também teria buscado ser um bom homem. Maria, Emilia, Manoel e Leonor, órfãos de mãe há 6 anos e recentemente tendo perdido o pai, João Gomes Soares, puderam contar a bondade e amor de Antonio Muniz nesse momento tão difícil. Morando na casa de Antonio com o próprio pai desde o falecimento da mãe, tais crianças, acredita-se, despertaram um sentimento de amor e zelo no homem, de um jeito que somente um filho poderia o fazer, ao ponto deste querer ser considerado pela justiça como responsável pelas crianças:

Ilmo. Sr. Dr Juiz de Direito

Diz Antonio Cabral Muniz que ha 6 annos tendo enviuvado João Gomes Soares passou este a residir com seus filhos menores Maria (atualmente com 12 annos), Emilia (com 8 annos), Manoel (com 7 annos) e Leonor (com 6 annos) em companhia do supplicante que com sua mulher se incumbirão desde então do tratamento desses menores; e como tenha o supplicante se afeiçoado aos menores, habituando-se a consideral-os como filhos e este para pedir a VS. digne se nomear o supplicante tutor dos ditos menores, visto ter falecido no dia 2 do corrente (certidão junta o referido Soares, não deixando parente a quem deva caber tal encargo.

P. a VS. deferimento.

\footnotetext{
${ }^{68}$ APHRP, Fundo "Processos Antigos", Caixa 118-A, Processo 92, grifo nosso.
} 
Ribeirão Preto, 8 de Março de 1901

Ao rogo de Antonio Cabral Muniz por não saber escrever [ilegível] ${ }^{69}$.

Maria, de 12 anos, Emilia, de 8 anos, Manoel, de 7 anos e Leonor, de 6 anos, teriam sido mantidos sob os cuidados de Antonio Muniz e sua esposa, continuando assim, a serem considerados como filhos por estes.

Adelino Norberto da Silva, possivelmente, também teria sido considerado um bom homem, principalmente pelo fato de ter recolhido Jeronymo em sua casa. O menino, órfão de mãe e abandonado pelo pai, assim como as outras crianças dos casos anteriores, teria tido a sorte de contar com o princípio de bondade e caridade de Adelino. Contudo, Adelino, talvez por outros problemas ou então pelo simples exercício de bondade realizado ao trazer Jeronymo para sua casa acreditou que tal ação já teria sido o suficiente. Entretanto, a condição de Adelino e Jeronymo sofreu a intervenção judicial para sua regularização:

Exmo. Sr. Dr. Juiz de Direito

Diz o Curador Geral de Orphãos que existindo em casa de Adelino Norberto da Silva, nesta cidade, um menor de nome Jeronymo, de des annos de idade, orphão de mãe e abandonado por seu pai eu se retirou d'esta cidade, sem que se saiba ao certo o seu destino, e, sendo necessario, portanto, dar-lhe um tutor, vem propor a V. Exa. afim de exercer esse cargo o mesmo Adelino Noberto da Silva, em cuja companhia ja vive o dito menor.

Nestes termos, p. deferimento.

Ribeirão Preto, 11 de julho de 1902

O Curador Geral de Orphãos Mario de Almeida Andrade ${ }^{70}$.

Nada mais teria sido acrescentado pelo Curador Geral de Órfãos, Mario de Almeida Pires, e Jeronymo, por fim, foi reconhecido juridicamente como pupilo de Adelino.

Já citada anteriormente, Marcílio (1998) comenta que a conduta de acolhimento de crianças órfãs e abandonadas seguia-se pela linha de uma assistência que tinha como principal argumento a caridade cristã. Assim, conforme o mecanismo da tutela tornou-se o instituto ao qual se recorria para criar uma criança, alguns buscavam esse mesmo instituto para regularizar uma possível situação de tutela e/ou soldada que teria tido início sem o respaldo da justiça.

Tanto Antonio d'Andrade quanto Antonio Cabral Muniz buscaram regularizar a tutela utilizando-se do argumento acerca de uma pressuposta afeição desenvolvida por estes em relação as crianças, considerando-as como filhas. Como já explicado por Marcílio (1998), tal conduta não apenas era vista com bons olhos, como também era estimulada. Considerando que o tipo de ação de tutela dativa foi o mais solicitado no período pesquisado, de acordo com o levantamento realizado por esse trabalho, observou-se que a argumentação utilizada para tal

\footnotetext{
${ }^{69}$ Idem, Caixa 102-A, Processo 84, grifo nosso.

${ }^{70}$ APHRP, Fundo "Processos Antigos", Caixa 47-A, Processo 69, grifo nosso.
} 
envolvia o fato do solicitante estar com a criança há um considerável tempo e, por isso, dizer ter se afeiçoado a esta. Pressupõe-se que, talvez, o argumento acerca do desenvolvimento da afeição direcionada a criança possa ter sido utilizado com estratégia para explicar e compensar essa possível demora em regularizar a tutela.

Ao que consta no terceiro caso supracitado, considera-se dois fatores, sendo a situação em que o menino Jeronymo já se encontrava sob poder de Adelino Norberto da Silva e que foi a pedido do Curador Geral de Órfãos que se regularizasse a tutela da criança. Com isto, observase uma possível resposta a um dos questionamentos que nortearam esse trabalho: o fato de que em nenhum momento do processo citado anteriormente foi esclarecido há quanto tempo a criança encontrava-se na companhia de Adelino e, principalmente, o fato de ter sido pela solicitação do Curador Geral de Órfãos que se regularizasse a situação. Observa-se, então, uma das lacunas verificadas no desenvolvimento não apenas desse processo, mas em muitos outros que também foram selecionados e que se assemelham a tal situação: como tornava-se de conhecimento público, não apenas pela sociedade civil, como também pela instituição jurídica da cidade, o fato de haverem crianças em situação de orfandade, abandono e sem um tutor? Pela historiografia do tema recuperada e pelas fontes jornalísticas já apresentadas, a própria sociedade civil com o auxílio dos periódicos locais tratavam de vigiar e informar acerca de tais situações, contribuindo - e até, por vezes, facilitando - com o trabalho do judiciário no que concernia as ações de intervenção e controle da população ribeirão-pretana.

\subsubsection{O trabalho dignifica o órfão}

Agenor acordou para mais um dia de serviço. Possivelmente, iria cuidar de algum afazer da casa onde residia por contrato ou auxiliar seu contratante em outro serviço mais especializado. Mais um dia longo de trabalho na vida de Agenor, mas isto não deveria ser visto como problema. Afinal, ele teve sorte em ser contatado por Ernesto Gomes Jardim, apesar de sua qualificação como filho de um ex-escrava, Maria, como também ganharia uma quantia razoável por isso. Ernesto, possivelmente, também era um bom homem, pois saberia medir a quantia razoável a ser paga pela quantidade de serviços que solicitaria para Agenor. Tal situação era considerada completamente normal, até mesmo o fato de que Agenor era uma criança de apenas 4 anos de idade:

Ilmo. Sr. Dr. Juiz de Orphãos Ernesto Gomes Jardim, fazendeiro, residente n'este termo, se propõe a assignar perante VS. O contracto de soldada do menor de nome Agenor, de 4 annos de idade, filho da ex escrava Maria, pagando pelos serviços do referido menor uma quantia 
rasoavel; por isso vem pedir a VS. se digne deferir esta, ordenando as medidas prescriptas por lei.

E.R.M.

Ribeirão Preto 9 de Julho de 1890

Ernesto Gomes Jardim ${ }^{71}$

Não importava se Agenor teria apenas 4 anos de idade. Considerando o período de transição e de reorganização que a cidade vinha sofrendo, o menino deveria ser grato pelo fato de ter um trabalho, mostrar serviço e ter a possibilidade em ser considerado como mais uma criança salva dos malefícios da rua e vícios familiares.

Gratidão também deveria ter Sebastião de Godoy. Órfão de pai e mãe, Sebastião, possivelmente, estaria sob os cuidados da rua e se contaminando com o vício da vadiagem. Contudo, também pelo exercício de bondade realizado pelo cidadão Alberto Ferraz de Abreu, este não só acolheu Sebastião, como também passou a considerar o menino apto a desempenhar serviços recebendo um bom ordenado para tal:

Illmo. Exmo. Sr Dr Juiz de Direito

Diz Alberto Ferraz de Abreu, lavrador residente neste municipio, que em sua companhia tem o menor Sebastião de Godoy, com 14 annos de idade, filho de João [Alegario] de Godoy e Idalnia de Godoy ambos já fallecidos, ganhando o dito menor a quantia de $20 \$ 000$ (vinte mil reis) por mes, como empregado do supplicante, a quem presta serviços leves, qual o de copeiro; e como o dito orphão não tenha tutor vem o supplicante requerer a V.Ex ${ }^{\mathrm{a}}$. seja admittido a fazer com ele contracto de soldada, devendo V.Ex ${ }^{\mathrm{a}}$. com parecer do Dr Curador Geral de Orphãos, [orbitrer] os salarios do menor e declamar quaes as condições do pagamento.

Ribeirão Preto, 15 de Fevereiro de 1902

Alberto Ferraz de Abreu ${ }^{72}$.

O menino de 14 anos trabalharia como copeiro para Alberto, sendo que este solicitou ao Curador Geral de Órfãos como e quando realizar o pagamento do serviço. Alberto, assim, possivelmente, demonstrava mais um gesto de bondade, colocando-se à disposição da forma mais justa em zelar e cumprir seu compromisso com Sebastião.

Contrariamente ao que contam as referências utilizadas nesse trabalho, observou-se que o mecanismo da contratação de serviços de crianças/jovens em Ribeirão Preto no período pesquisado, foi menos utilizado do que a solicitação de tutela. Ainda e conforme a lei, mesmo que as crianças em situação de tutela e contratação devessem ser educadas e instruídas, tal fato também não foi observado. Conforme já informado anteriormente, o tipo de ação que tinha como finalidade o contrato de soldada no período foi localizado em apenas 20 processos, sendo que os de tutela dativa foram localizados em 67 processos. Ainda, deve-se considerar os processos que tinham como tipo de ação a prestação de contas de soldada ( 8 processos) e

\footnotetext{
${ }^{71}$ APHRP, Fundo "Processos Antigos", Caixa 72-A, Processo 35, grifo nosso.

${ }^{72}$ APHRP, Fundo "Processos Antigos", Caixa 114-A, Processo 88.
} 
prestação de contas de soldada + remoção de contratante (1 processo), contabilizando o pressuposto número de 29 contratações de serviços de crianças/jovens na cidade entre 1874 e 1914. Interessante também notar que foi no ano de 1890 o maior número de produção tanto de processos de contrato de soldada (11 processos) e prestação de contas de soldada (5 processos), considerando, principalmente, o que já foi abordado anteriormente nesse trabalho acerca da Lei do Ventre Livre (BRASIL, 1871), a qual entrou em vigor no ano de 1871.

Os processos selecionados que tratavam tanto da contratação quanto da prestação de contas de soldada foram poucos explorados pelo próprio judiciário da época, uma vez que contavam com poucas páginas ou, por vezes, apenas com uma, sendo esta a petição inicial de solicitação do contrato. Ainda, o texto que compunha a primeira petição inicial apresentada apenas informava a possível situação em que a criança/jovem a ser contratada se encontrava (órfã, abandonada, entre outros), como também acerca de uma quantia a ser paga para que esta prestasse os serviços solicitados, sendo que, por vezes, não havia um detalhamento acerca desta quantia.

Além de se observar o que foi dito anteriormente acerca da não informação específica sobre a quantia ser paga à criança que prestaria o serviço firmado via contrato, o solicitante Ernesto Gomes Jardim informou que o menino Agenor tinha apenas 4 anos de idade. Com isto, é possível pressupor que o contrato de soldada não serviu apenas para o ato de contratação, mas também como uma regularização do trabalho infantil na época, uma vez que a criança em questão estava com apenas 4 anos de idade e logo pode-se pressupor, principalmente, as limitações físicas que esta teria ao exercer o que lhe seria imposto.

Observa-se que o solicitante Alberto Ferraz de Abreu foi um dos pouquíssimos a dar informações mais detalhadas acerca da quantia que pretendia pagar à Sebastião de Godoy, como também o tipo de serviço que seria realizado por este. Ainda que o contrato de soldada, conforme explica Azevedo (1996), foi criado a partir de uma extensão da tutela direcionada às crianças com posses em situação de orfandade e/ou abandono, não foi localizado na legislação e obras de referência do Direito da época investigada nenhum tipo de orientação acerca de uma obrigatoriedade de informações mais completas nos pedidos de contratação de serviços de crianças/jovens.

Importante, ainda, observar que mesmo com a Lei $n^{o}$. 108, de 11 de outubro de 1837 "Dando várias providências sobre os contratos de locação de serviços dos colonos" (BRASIL, 1837), o Decreto $n^{o}$. 2.827, de 15 de março de 1879 - "Dispondo o modo como deve ser feito o contrato de locação de serviços" (BRASIL, 1879) e o Decreto $n^{o}$. 1.313, de 17 de janeiro de 1891 - "Estabelece providencias para regularizar o trabalho dos menores empregados nas 
fabricas da Capital Federal" (BRASIL, 1891), a utilização do contrato de soldada se fazia existente e direcionado às crianças. Ainda que não se tenha a intenção nesse trabalho em investigar as motivações de tal situação, sugere-se a necessidade de pesquisas para uma investigação acerca do tema, uma vez que, acredita-se, tais estudos poderão auxiliar na compreensão da utilização do contrato de soldada em relação a existência de outras leis e decretos com finalidade semelhante. Contudo, o que se pode pressupor diante da exposição feita por este trabalho é a de que, possivelmente, e mesmo com outros dispositivos que regularizariam a contratação de serviços de crianças/jovens, o contrato de soldada foi utilizado como instrumento não apenas de vigilância e controle sob a infância desvalida na cidade, mas também como instrumento de encaminhamento para sanar uma possível situação de orfandade associada ao abandono, pobreza e marginalidade em Ribeirão Preto. Pressupõe-se, assim, que o pensamento da época estudada, diante ao específico caso da soldada, seria algo como: "o trabalho dignifica o órfão, desde que ele não entenda isso".

\subsubsection{A paradoxal condição feminina ribeirão-pretana: ser mulher e ser mãe pelo/no judiciário}

Em um dia qualquer, em meados do mês de junho do ano de 1899, Antonio Gotar, possivelmente, teve um dia atarefado. Pai de família, talvez ele tenha passado bom tempo fora casa trabalhando ou então resolvendo questões pessoais. Já em casa, Antonio aproveitaria o tempo em que lá se encontraria somente para descansar e esperar por sua mulher, Amalia. Talvez esta tivesse saído para também resolver algo da casa ou, então, estivesse atrás de seus seis filhos que poderiam estar na escola ou brincando na rua, trazendo-os de volta para casa afim de que todos se resguardassem ao final dia. Talvez o dia já estivesse escurecendo, terminando, e Antonio continuava sozinho em casa. Afinal, onde estariam todos e por qual motivo ainda não voltaram para casa? Tomado por um sentimento estranho, Antonio teria ido verificar os pertences dos filhos e pouca coisa se encontrava guardada onde deveria estar. Os pertences de sua esposa também se encontravam mal arrumados e até mesmo jogados pelo cômodo do casal. A mala estaria desaparecida também. Teria Amalia ido embora de sua casa levando seus seis filhos consigo? Por que faria tal coisa? Afinal, onde se viu uma boa esposa abandonar o próprio lar levando seus filhos para um local e futuro desconhecidos? Amalia, que mulher inconsequente, apenas demonstrou sua falta de decência.

Antonio, assim, decidiu agir corretamente. Sabendo de seu direito como chefe de família, procurou o Juiz de Direito da cidade para colocar fim a tal história: 
Exmo. Sr. Dr. Juiz de Direito

Diz Antonio Gotar infra assignado que é casado com Amalia da qual tem os seguintes filhos, Antonio de 15 annos de idade, Cristina de 13 annos, Lucia de 11 annos, Giacomo 9 anno, Quirino de 8 annos e Maria de 4 annos.

Acontece que tendo sua mulher abandonado sua casa levou consigo os filhos acima referidos, e como ao pae compete estabelecer o domicílio de sua mulher e filhos enquanto menores sob cuja guarda e vigilancia se devem achar e constituindo a permanencia de suas filhas em companhia gera perigo para a sua honestidade vem o suplicante requerer a V. Exa. ordenar a expedição de mandando afim de que sejam apreendidos seus filhos em poder de quem se acharem e entregues as supplicante.

Nestes termos, p. a V. Exa. deferimento, D. e A. este expedindo-se mandado.

E.R.M.

Ribeirão Preto, 22 de junho de 1899

Antonio $\operatorname{Gotar}^{73}$.

Ao tomar tal decisão, Amalia apenas mostrou seu verdadeiro caráter como uma mulher sem limites e que não respeitava o próprio lar e muito menos o próprio marido. Assim, preocupado com a educação de Antonio, Giacomo e Quirino e, principalmente, com a má referência feminina para Cristina, Lucia e Maria, Antonio Gotar entrou com um pedido de apreensão de seus próprios filhos para que estes pudessem ter a oportunidade de serem salvos a tempo. Não se sabe por quanto tempo tal situação durou e muito menos qual o destino dos envolvidos. Contudo, uma coisa era certa: Amalia carregaria a estigma de mulher desonesta para o resto de sua vida.

Outra mulher que, possivelmente, se encontrava em apuros foi Florencia da Silva. Viúva e com um filho pequeno para criar, Florencia talvez estivesse em busca de algum trabalho e contando com a solidariedade de pessoas próximas. Contudo, era sabido que uma mulher viúva não daria conta de arcar com a responsabilidade de criar e prover meios de manter seu filho, a não ser que tivesse um homem ao seu lado, sendo de preferência seu finado marido. Como resolveria Florencia tal questão?

Mal sabia Florencia que Francisco Lourenço, tio do menino, já estava tomando providências acerca dos cuidados do menino Victorino do Santos:

Exmo. Sr. Dr. Juiz de Direito da Comarca.

Diz o abaixo assignado domiciliado nesta cidade, que tendo um sobrinho e afiliado de nome Victorino dos Santos com seis annos de idade em poder da mãe Florencia da Silva, sendo esta viúva, e de procedimento muito irregular ao ponto de sempre maltratar este menor, não podendo continuar em sua companhia, vem respeitosamente solicitar de V. Excia. a nomeação de tutor do dito menor e pedindo mandar intimar a supplicada para entrgar dito menor em juizo.

Nestes termos p. deferimento

Ribeirão Preto, 29 de maio 1909

Francisco Lourenço ${ }^{74}$.

\footnotetext{
73 APHRP, 1899, Fundo "Processos Antigos", Caixa 68-A, Processo 79, grifo nosso.

${ }^{74}$ APHRP, 1909, Fundo "Processos Antigos", Caixa 158-A, Processo 126, grifo nosso.
} 
Preocupado com futuro de seu sobrinho Victorino, Francisco tinha o respaldo da lei para fazer o que fosse melhor para o menino. Afinal, que tipo de referência Victorino poderia ter ao continuar com sua mãe, mulher viúva e que por sua condição, estaria desenvolvendo um tipo de comportamento completamente irregular do que lhe era esperado?

Contrariamente à Amalia e Florencia, Mathilde Maria Antonia de Andrade teve sorte, sendo esta principalmente por ser, possivelmente, de uma camada mais abastada ou então por ter contraído tal status financeiro pelo matrimônio. Ainda, teve a condição de ter acesso a maiores informações sobre seus direitos como mãe, como também acesso à bons advogados. Mathilde procurou a justiça para que esta fosse mantida como tal, para que seus filhos Urbano, Domingas e Valeriana, assim como seus bens herdados, retornassem ao seio materno:

Illmo. e Exmo. Sr. Dr. Juiz de Direito

Diz Mathilde Maria Antonia de Andrade, por seus advogados abaixo assignados, que tendo sido o cidadão João Teixeira de Carvalho nomeiado tutor dos menores Urbano, Domingas e Valeriana, filhos naturais da suplicante e do falecido Francisco Rodrigues dos Santos Bomfim, vem perante V. Excia. reclamar contra essa nomeação por illegal e arbitraria, porquanto, conforme atenta Clovis Bevilaqua - Direito das Familias, pag 508, nota $4^{\text {a }}$, e já foi decidido pelas Relações de Porto Alegre e A. [ilegível] do Maranhão em Accs de 21 de Outubro de 1899 e 26 de novembro de 1895 em face do nosso direito vigente, ás mães, sejam viúvas, ou solteiras, compete o patrio poder sobre a pessoa e bens de seus filhos.

$<<$ Clovis citado: "A mãe tem hoje o patrio poder, em face de nossa lei, e tal se deve entender, tanto da legitima, como da ilegítima Acc. do Superior Tribunal de Justiça do Rio Grande do Sul: “Considerando que o Dec. de 24 de Janeiro de 1890, que estabeleceu no Brazil o casamento civil dá á viúva e á mãe solteira o patrio poder sobre seus filhos, e nesse caso desempenha a mulher as funções de legitima tutora de seus filhos, os representa em juizo por si só, sendo eles impuberes, e os acompanha na defesa de seus direitos quando puberes; Considerando que, depois da promulgação do cit. decreto é um verdadeiro atentado á lei e aos direitos da mulher a pratica geral [ilegível] [ilegível] de se nomeiar tutor a menores filhos da mulher solteira.

E como a suplicante se conserva no estado de solteira vem por isso requerer a $\mathrm{V}$. Excia. se digne de destituir o tutor nomeado, D. A. esta, mandando entregar as pessoas e bens dos ditos seus filhos á suplicante para que possa sobre eles exercer todo esse conjunto de direitos que constitue o patrio poder.

P. deferimento.

Ribeirão Preto, 22 de novembro de 1901

Os Advogados

Eduardo Lira Ribeiro

Brenno dos Santos ${ }^{75}$.

Mathilde indicou que se mantinha solteira após enviuvar de Francisco Rodrigues dos Santos Bomfim, demonstrando assim, possivelmente, boa conduta ao não se deixar envolver nos perigos de um novo amor. Ainda, conhecendo o havia ditado Beviláqua através dos advogados Eduardo Lira Ribeiro e Brenno dos Santos, ninguém poderia duvidar da capacidade desta nobre mulher em ter aptidão para zelar por seus filhos.

\footnotetext{
75 APHRP, 1901, Fundo "Processos Antigos", Caixa 111-A, Processo 86, grifo nosso.
} 
Diziam por aí em tom de deboche que o artista José Dolacio Mendes havia perdido sua musa inspiradora. Há cerca de três anos Maria Custodia Velasco abandonou seu lar, seu marido e seu filho, mudando-se para a Villa de Cravinhos. Não era conhecido o motivo que levou Maria a ir embora, mas era certo que tal ação só mostrou o quanto ela não era digna do matrimônio em que se mantinha.

Assim, nestes últimos três anos que se passou, José, acredita-se, tentou seguir com sua vida e criou seu filho Luizisso. Contudo, Maria, após três anos, resolveu aparecer: aproveitando uma viagem que José precisou fazer, possivelmente por motivo de trabalho, a mulher retirou seu filho da casa, levando-o consigo para também residir na Villa de Cravinhos. Talvez, por não imaginar que a mulher fosse capaz de fazer tal coisa, José acreditou que seu filho, já com doze anos de idade, manter-se-ia sem qualquer problema aguardando o retorno de seu pai. Assim, preocupado com seu filho por saber de boatos os quais Maria estaria levando uma vida fácil, José procurou seus direitos de pai:

\footnotetext{
Exmo. Sr. Dr. Juiz de Direito

Diz José Velasco, artista residente nesta cidade que é cazado legitimamente com Maria Custodia Velasco. Acontece que por desinteligencia no [ilegível] do seu casal a sua mulher abandonando das [ilegível] [ilegível] retirou-se desta cidade á casa de treis anos transferindo o seu domicilio agora recentemente passa a Villa de Cravinhos desta Comarca. Do seu matrimonio existe um filho menor que conta dose anos de edade e que na ausência do supplicante que teve necessidade de fazer uma pequena viagem a sua referida mulher arrebatou do seu poder condizendo-o para a sua residência na quella localidade. Succede porem, que, o procedimento da referida Custoia desde que abandonou o seu lar tem sido irregularíssimo sendo alias certo publico e notório que por meio de uma vida fácil e deshonrosa ella processa os meios para a sua subsistencia. Por isso, quer o supplicante que V. Ex. se digne de ordenar a apreensão e entrega da referida creança que tem o nome de Luizisso de acordo com a legislação pátria que rege a matéria e que dá ao supplicante as regalias do pátrio poder.

Nestes termos pede deferimento passando-se mandando depois de D. e A. esta. Ribeirão Preto 27 de Junho de 1899

José Dolacio Mendes ${ }^{76}$.
}

Pobre menino Luizisso, envolvido nos desentendimentos de seus pais, os quais tiveram que procurar pelo controle da situação agindo até as últimas consequências. Não é possível saber como tal episódio terminou, mas pelo o que consta nos autos até certo período, José teve seu direito de pai reestabelecido.

Conforme observado pelas petições iniciais citadas, como também por outras pontuações acerca do que o legislativo determinava sobre seus direitos anteriormente, a questão das mulheres, por vezes, era colocada de formas diferentes. Contestava-se sua autoridade moral e financeira para com a criação dos filhos, tendo em vista o pátrio poder, como também como

\footnotetext{
${ }^{76}$ APHRP, 1899, Fundo "Processos Antigos", Caixa 86-A, Processo 80, grifo nosso.
} 
esta se portava diante da sociedade. Observou-se que o argumento acerca da falta de cuidados e denúncia de maus tratos foi utilizado com fins de obter-se um respaldo da própria lei para o deferimento da solicitação realizada via processo. Ainda, pressupunha-se uma preocupação acerca da falta de procedimento moral enquanto conduta social da mulher e como tal poderia ressoar e influenciar as crianças, principalmente as filhas mulheres.

Conforme já explicado pelas Ordenações Filipinas, a mulher apenas teria direito a permanecer com seus filhos se esta comprovasse boa conduta moral em sociedade e isso, por vezes, era considerado a partir do fato desta se propor a um novo casamento ou não. Conforme determina o Livro IV das Ordenações Filipinas, Título CII, parágrafo 4:

E se alguma mulher, sendo viuva, for dada por Tutora, ou Curador de seus filhos, ou netos na maneira que dito he, e se casar, e por isso lhe for removida e tirada a Tutoria ou Curadora, se ella depois viuvar, e quiser tornar a ser Tutora ou Curador dos ditos seus filhos, ou netos, não lhe será consentido. (ALMEIDA, 1870b, p. 1000).

Observa-se que no pedido de Mathilde Maria Antonia de Andrade não somente foi utilizado o que a lei previa para mulheres em sua situação (viúva e conservando-se em tal estado), como também se tomou como referência uma das obras clássicas acerca do direito português e brasileiro, Direito de Família, de Clóvis Beviláqua (1896). Contudo, é necessário observar que tal solicitação se fez via seus advogados, uma vez que a família provinha de recursos financeiros, o que, pressupõe-se, fez com que o entendimento de Mathilde acerca de seus direitos perante a lei deu-se pela possível orientação realizada.

Observa-se, a exemplo da solicitação de José Velasco e o que mesmo descreve sobre Maria Custodia Velasco, que a depender da condição financeira, em primeiro lugar, seguido de uma conduta moral considerada digna para a mulher que era mãe, os processos prosseguiriam no instituto jurídico até que fossem deferidos ou não a favor desta. Ainda, observa-se que a maioria dos processos em que a mulher foi descrita como tendo um comportamento considerado irregular, principalmente se associado a imagem de mãe e as funções que essa condição pressupõe-se incumbir, ainda que sem testemunhas para pavimentar tal denúncia, o deferimento, em sua maioria, era contrário à mulher. Visto isso, pressupõe-se a existência de perspectivas do judiciário da época em se governar a instituição familiar, principalmente em casos onde o pai era falecido ou ausente, considerando o pátrio poder - mesmo com decretos e outras leis que passaram a dar mais direitos às mulheres. Ainda, ousa-se pressupor que a mentalidade da sociedade na época pesquisada contribuiu para essa perspectiva em se governar os considerados mais vulneráveis, como mulheres e crianças. Mathilde, talvez, teve a sorte de dispor uma quantia necessária para procurar seus direitos, demonstrando que suas posses seriam 
provas de sua competência, uma vez que o pensamento da época correlacionava-se a lógica de que o pobre se mantinha em tal situação por única e exclusiva incompetência em não conseguir enriquecer. Já a incontestável situação de Amalia, Florencia e Maria pela falta do chamado "procedimento moral", tais continuaram estigmatizadas não apenas por serem mulheres, mas também por, possivelmente, serem pobres. 


\section{CONSIDERAÇÕES FINAIS}

Ribeirão Preto se desenvolveu através de paradoxos sociais. A cidade cresceu em uma surpreendente velocidade, buscando o progresso, a ordem e a modernidade, uma vez que tais adjetivos não eram passíveis de existir isoladamente. Contudo, tal busca levou para exatamente aquilo que era considerado como incoerente para uma cidade com tais prerrogativas: o aumento populacional levou Ribeirão Preto a lidar com problemas relacionados à moradia, alimentação e trabalho, agravando-se a situação dos mais pobres e, especificamente os mais vulneráveis, como as crianças. Ainda, o advento da Lei do Ventre Livre, principalmente, contribuiu para o problema da infância pobre e a abandonada na cidade, sendo este em específico tratado pelo instrumento da soldada, pelo qual observou-se a possibilidade de obtenção de mão de obra barata (e, por vezes, gratuita) de crianças órfãs, abandonadas ou que simplesmente buscavam a própria sorte em pequenos ofícios ou nas ruas.

Acredita-se que pela demora na instalação de locais na cidade que cumprissem com o dever em auxiliar à infância pobre, abandonada e/ou órfão, a remediação pelas vias jurídicas tornou-se uma saída interessante para os governantes da época: além de promover toda uma limpeza nas ruas da cidade, visando retirar as crianças do pressuposto "vício da vadiagem" associado aos pobres, tais medidas tinham advento legal da justiça para a realização de tutelas e contratos de soldada, considerando o fato de que esta não teria a necessidade em financiar exclusivamente tais medidas. Observa-se que tal incompetência e inoperância no tratamento da infância desvalida na cidade teriam sido ofuscados pela intensa intervenção do judiciário a partir da sugestão de incorporação da tutela realizado por alguns periódicos locais, como também pela ação direta de autoridades, sugerindo possíveis tutores e/ou contratantes para uma determinada criança que estaria em alguma situação considerada inadequada e arriscada, mas, principalmente, para mantê-la sob as rédeas das normas locais.

Pressupõe-se que tal sistema era alimentado pelo pensamento progressista da época no que se referia em como lidar com população desvalida. A busca pela modernidade em Ribeirão Preto pode ter sido impulsionada através das vias jurídicas, uma vez que esta passou a ser utilizada para tratar o problema específico da infância desvalida, considerando que, por vezes, os processos analisados tinham como alvos principais mulheres e crianças - classificadas pela legislação da época como sujeitos vulneráveis e inaptos -, sendo que o controle, vigilância e manutenção da ordem que poderia ser afetada pelo possível comportamento inconsequente destas passaria, assim, a ser resolvido através da lei. Ainda que pudessem haver inciativas e pessoas que realmente visassem a garantia do cuidado da infância, o judiciário foi cada vez 
mais procurado para resolver situações referentes a esta, ainda que sem a necessidade comprovada de tal intervenção.

O recorte temporal proposto pelo trabalho encerra-se no ano de 1917, ano no qual nosso primeiro Código Civil brasileiro iniciava sua vigência, e, coincidentemente, também o mesmo ano de fundação do primeiro asilo de órfãos da cidade, o Asilo Anália Franco. Ainda que a seleção de processos utilizados como corpus principal da pesquisa tenha considerado os que foram produzidos até o ano de 1917, pode-se observar durante tal seleção que processos de tutela, contratação de soldada ou de qualquer outro tipo que se correlacionariam com tais ações foram produzidos até a década de 1930 - até mesmo após a extinção do contrato de soldada, ocorrida no mesmo período. Tal continuação na aplicação da soldada teria se dado pela ineficiência de locais próprios para o acolhimento de crianças órfãs ou então pela possibilidade de obtenção de mão de obra barata para serviços domésticos? Assim, observa-se a necessidade de uma investigação mais profunda acerca da real aplicação do contato de soldada na cidade, considerando sua permanência como meio para tratar o problema local da infância desvalida.

Ainda, e não mesmo importante, a pesquisa também levanta a necessidade em se investigar questões de gênero no que se refere ao desenvolvimento do poder judiciário brasileiro e sua relação com as mulheres. Mesmo que, atualmente, observa-se significativas mudanças acerca dos direitos estabelecidos pelas/das mulheres, ainda podemos encontrar muitas contradições sobre o que foi estabelecido na letra da lei com o que realmente é realizado, observando-se uma cultura de julgamento e desamparo de mulheres construída historicamente na sociedade brasileira.

A questão da infância desvalida, não somente a ribeirão-pretana, mas também como a brasileira, foi construída através do histórico de luta e resistência, a começar pelas próprias crianças. Observa-se, ainda, que tal necessidade de luta e resistência permanece, visto tantos retrocessos em que nos encontramos atualmente, a exemplo da discussão da redução da maioridade penal, do genocídio de crianças e jovens negros nas periferias e da exploração do trabalho infantil, tão recorrentes no cenário brasileiro. Ainda que a proposta do trabalho foi pensada a partir da reconstrução de situações ocorridas no final do século XIX e início do século $\mathrm{XX}$, nunca se tornou tão urgente e necessária a revisão de direitos adquiridos, uma vez que conclui-se a existência - e persistência - de uma mentalidade perversa e estratégica contra a infância pobre, alimentada desde o princípio da colonização brasileira. 


\section{REFERÊNCIAS}

A CIDADE. Barbaro espancamento de uma menor. Ribeirão Preto, ano VIII, 13 de dezembro de 1912, n. 2503, p. 1.

. Defloramento. Ribeirão Preto, ano XII, 19 de novembro de 1916, n. 3836, .2.

. Mandado de prisão. Ribeirão Preto, ano XI, 5 de janeiro de 1915, n. 8277, p. 1.

Menor demente. Ribeirão Preto, ano VIII, 15 de junho de 1912, n. 2363, p. 1.

1.

Menor desaparecida. Ribeirão Preto, ano XIV, 8 de março de 1918, n. 4443, p.

Menor explorada. Ribeirão Preto, ano XII, 19 de março de 1916, n. 3637, p. 1.

. Notas policiaes. Ribeirão Preto, ano I, 21 de janeiro de 1905, n. 18, p. 1.

. Notas policiaes. Ribeirão Preto, ano I, 27 de janeiro de 1905, n. 23, p. 1.

. Pela policia, Ribeirão Preto, ano VIII, 26 de março de 1912, n. 2304, p. 1.

. [Título não informado]. Ribeirão Preto, ano I, 8 de fevereiro de 1905, n. 33, p. 2.

2.

. [Título não informado]. Ribeirão Preto, ano I, 12 de fevereiro de 1905, n. 37, p.

ALBA, Felipe Camilo Dall'. Os três pilares do Código Civil de 1916: a família, a propriedade e o contrato. Revista Páginas de Direito, Porto Alegre, ano 4, n. 189, 2004. Disponível em: <http://www.tex.pro.br/home/artigos/109-artigos-set-2004/5147-os-tres-pilares-docodigocivil-de-1916-a-familia-a-propriedade-e-o-contrato>. Acesso em: 28 ago. 2015.

ALMEIDA, Candido Mendes de. Ordenações Filipinas - Livro I. Recompiladas por mandado d'El-Rey D. Philippe I. Decima-quarta edição, segundo a primeira de 1603, e a nona de Coimbra de 1821. Rio de Janeiro: Typographia do Instituto Philomathico 1870a.

Disponível em: <http://www2.senado.leg.br/bdsf/item/id/242733>. Acesso em: 30 jun. 2015.

Ordenações Filipinas - Livro IV. Recompiladas por mandado d'El-Rey D.

Philippe I. Decima-quarta edição, segundo a primeira de 1603, e a nona de Coimbra de 1821. Rio de Janeiro: Typographia do Instituto Philomathico 1870b. Disponível em: <http://www2.senado.leg.br/bdsf/item/id/242733>. Acesso em: 30 jun. 2015.

. Ordenações Filipinas - Livro V. Recompiladas por mandado d'El-Rey D.

Philippe I. Decima-quarta edição, segundo a primeira de 1603, e a nona de Coimbra de 1821. Rio de Janeiro: Typographia do Instituto Philomathico 1870c. Disponível em: <http://www2.senado.leg.br/bdsf/item/id/242733>. Acesso em: 30 jun. 2015.

ARIÈS, Philippe. História Social da Criança e da Família. Tradução de Dora Flaksman. 2. ed. Rio de Janeiro: Guanabara, 1986. 
ARIZA, Marília Bueno de Araújo. Assoldados e tutelados: trabalho e emancipação de menores em São Paulo na segunda metade do XIX. In: $\mathbf{7}^{\mathbf{0}}$ ENCONTRO ESCRAVIDÃO E LIBERDADE NO BRASIL MERIDIONAL, 2015. Anais... Curitiba: UFPR, 2015.

ARQUIVO PÚBLICO E HISTÓRICO DE RIBEIRÃO PRETO. História. Disponível em: $<$ http://www.ribeiraopreto.sp.gov.br/scultura/arqpublico/i14index.php?pagina=/scultura/arqpu blico/historia/i14indice.htm>. Acesso em: 2 jul. 2015.

AZEVEDO, Gislane Campos. A tutela e contrato de soldada: a reinvenção do trabalho compulsório infantil. História Social, Campinas, n. 3, p. 11-36, 1996.

"De Sebastianas e Geovannis": o universo do menor nos processos dos juízes de órfãos da cidade de São Paulo (1871-1917). 1995. Dissertação (Mestrado)-Pontifícia Universidade Católica de São Paulo, São Paulo, 1995.

BASSANEZI, Maria Silvia C. Beozzo (Org.). São Paulo do passado: dados demográficos 1886. Núcleo de Estudos de População (NEPO), v. 4, Universidade Estadual de Campinas, 1999. Disponível em: <http://www.nepo.unicamp.br/publicacoes/censos/1886.pdf>. Acesso em: 25 set. 2015.

São Paulo do passado: dados demográficos - 1872. Núcleo de Estudos de População (NEPO), v. 3, Universidade Estadual de Campinas, 1998. Disponível em: <http://www.nepo.unicamp.br/publicacoes/censos/1872.pdf>. Acesso em: 25 set. 2015.

BASTOS, Ana Cristina do Canto Lopes. Nas Malhas do Judiciário: menores desvalidos em autos de tutela e contrato de órfãos em Bragança-SP (1889-1927). 2012. Tese (Doutorado)Faculdade de Educação, Universidade Estadual de Campinas, Campinas, 2012.

; KUHLMANN JR., Moysés. Órfãos tutelados nas malhas do judiciário

(Bragança-SP, 1871-1900). Cadernos de Pesquisa, v. 39, n. 136, p. 41-68, jan./abr. 2009.

BEVILÁQUA, Clóvis. Direito de família. Recife: Ramiro M. Costa \& Filhos, 1896.

Disponível em: <http://www.lexml.gov.br/urn/urn:lex:br:rede.virtual.bibliotecas:livro:1905 ;000119768>. Acesso em: 28 set. 2015.

BOTIN, Lívia Maria. Trajetórias cruzadas: meninos (as), moleques e juízes em Campinas (1866-1899). 2007. Dissertação (Mestrado)-Instituto de Filosofia e Ciências Humanas, Universidade Estadual de Campinas, Campinas, 2007.

BRASIL. Decreto no $\mathbf{1 8 1}$, de 24 de janeiro de 1890. Promulga a lei sobre o casamento civil. Rio de Janeiro, 1890.

Decreto $\mathrm{n}^{\mathbf{0}}$. 1.313, de 17 de janeiro de 1891. Estabelece providencias para regularizar o trabalho dos menores empregados nas fabricas da Capital Federal. Rio de Janeiro, 1891.

Decreto $\mathbf{n}^{\mathbf{0}}$. 2.827, de 15 de março de 1879. Dispondo o modo como deve ser feito o contrato de locação de serviços. Rio de Janeiro, 1879. 
Lei de 13 de setembro de 1830. Regula o contrato por escrito sobre prestação de serviços feitos por brasileiro ou estrangeiro dentro ou fora do Império. Rio de Janeiro, 1830.

. Lei $\mathbf{n}^{\mathbf{0}}$. 108, de 11 de outubro de 1837. Dando várias providencias sobre os contratos de locação de serviços dos colonos. Rio de Janeiro, 1837.

. Lei $n^{0} .581$, de 4 de setembro de 1850. Estabelece medidas para a repressão do tráfico de africanos neste Império. Rio de Janeiro, 1850.

Lei $\mathbf{n}^{0}$. 2.040, de 28 de setembro de 1871. Declara de condição livre os filhos de mulher escrava que nascerem desde a data desta lei, libertos os escravos da Nação e outros, e providencia sobre a criação e tratamento daqueles filhos menores e sobre a libertação anual de escravos. Rio de Janeiro, 1871.

Lei $\mathbf{n}^{\mathbf{0}}$. 3.353, de 13 de maio de 1888. Declara extinta a escravidão no Brasil. Rio de Janeiro, 1888.

Lei $\mathbf{n}^{\mathbf{0}}$. 3.701, de $\mathbf{1}^{\mathbf{0}}$ de janeiro de 1916. Código Civil dos Estados Unidos de Brasil. Rio de Janeiro, 1916.

BRIOSCHI, Lucila Reis. Criando história: paulistas e mineiros no nordeste de São Paulo (1725-1835). 1995. Tese (Doutorado)-Faculdade de Filosofia, Letras e Ciências Humanas, Universidade de São Paulo, São Paulo, 1995.

CALSANI, Rodrigo de Andrade. Nos corredores dos cafezais: o cotidiano econômico dos italianos na terra "rossa" (1887-1914). In: PERINELLI NETO, Humberto; PAZIANI, Rodrigo Ribeiro; MELLO, Rafael Cardoso de. Nos tempos das cidades: História, Cultura e Modernidade em Ribeirão Preto, SP (1883-1929). Jundiaí: Paco Editorial, 2014, p. 131-158.

CARVALHO, José Pereira de. Primeiras Linhas sobre o Processo Orphanologico. 2. ed. Rio de Janeiro: B. L. Garnier - Livreiro Editor, 1888. Disponível em: <http://www2.senado.leg.br/bdsf/item/id/227313>. Acesso: 27 ago. 2015.

. Primeiras Linhas sobre o Processo Orphanologico. Parte Segunda. Rio de Janeiro: B. L. Garnier - Livreiro Editor, 1880. Disponível em: <http://www2.senado.leg.br/bdsf/item/id/227313>. Acesso em: 27 ago. 2015.

CASTRO, Cíntia Regina Czysz de. O discurso sobre a menoridade nos processos do judiciário em Ribeirão Preto durante a República Velha (1903-1927). Relatório Final de Atividades de Iniciação Científica pela Fundação de Amparo à Pesquisa do Estado de São Paulo - FAPESP. Faculdade de Filosofia, Ciências e Letras de Ribeirão Preto, Ribeirão Preto, 2010.

COSTA, Jurandir Freire. Ordem médica e norma familiar. 5. ed. Rio de Janeiro: Edições Graal, 2004.

DAVID, Alessandra. Tutores e tutelados: a infância desvalida em Franca (1850-1888). 1997. Dissertação (Mestrado)-Faculdade de História, Direito e Serviço Social, Universidade Estadual Paulista "Júlio de Mesquita Filho", Franca, 1997. 
DE CICCO, Cláudio. Direito: tradição e modernidade. São Paulo: Ícone, 1993.

DE TILIO, Rafael. Casamento e sexualidade em Processos Judiciais e Inquéritos Policiais na Comarca de Ribeirão Preto (1871 a 1942): concepções, valores e práticas. 2005. Dissertação (Mestrado)-Faculdade de Filosofia, Ciências e Letras de Ribeirão Preto, Universidade de São Paulo, Ribeirão Preto, 2005.

Inquéritos Policiais e processos de crimes sexuais: estratégias de gênero e representações da sexualidade. 2009. Tese (Doutorado)-Faculdade de Filosofia, Ciências e Letras de Ribeirão Preto, Universidade de São Paulo, Ribeirão Preto, 2009.

DIÁRIO DA MANHÃ. Casamento na policia. Ribeirão Preto, ano XIV, 9 de janeiro de 1913, n. 4076, p. 1.

. Creança perdida. Ribeirão Preto, ano XIII, 21 de março de 1912, n. 3850, p. 1.

p. 2 .

. Creança abandonada. Ribeirão Preto, ano XIV, 21 de janeiro de 1913, n. 4086, . Creança á venda. Ribeirão Preto, ano XVI, 12 de junho de 1912, n. 3904, p. 1.

. Demente. Ribeirão Preto, ano XIV, 15 de junho de 1912, n. 3907, p. 1.

. Mendigo sem o ser. Ribeirão Preto, ano XV, 13 de dezembro de 1913, n. 4338,

p. 1.

. Menor fujão. Ribeirão Preto, ano XV, 16 de julho de 1913, n. 4220, p. 1.

. Menores dementes. Ribeirão Preto, ano XIV, 11 de janeiro de 1913, n. 4078, p.

2.

No Barracão - Uma demente, creanças abandonadas. Ribeirão Preto, ano XV, 11 de julho de 1913, n. 4216, p. 1.

informada].

Pela policia. Ribeirão Preto, ano XIII, 7 de maio de 1912, n. 3873, p. [não

. Rapto. Ribeirão Preto, ano XIII, 15 de maio de 1912, n. 3880, p. 2.

. [Título não informado]. Ribeirão Preto, ano XIV, 11 de janeiro de 1913, n. 4078,

p. 1 .

. [Título não informado]. Ribeirão Preto, ano XIV, 17 de janeiro de 1913, n. 4081, p. 2.

DOIN, José Evaldo de Mello et al. A Belle Époque caipira: problematizações e oportunidades interpretativas da modernidade e urbanização no Mundo do Café (1852-1930) - a proposta do Cemumc. Revista Brasileira de História, São Paulo, v. 27, n. 53, p. 91-122, 2007. 
DONZELOT, Jacques. A Polícia das famílias. Tradução de M. T. da Costa Albuquerque; Revisão técnica DE J. A. Guilhon Albuquerque. 2. ed. Rio de Janeiro: Edições Graal, 1986.

FERREIRA, Aurélio Buarque de Holanda. Novo dicionário Aurélio de língua portuguesa. 3. ed. Curitiba: Positivo, 2004.

FLORENTINO, Manolo. De escravos, forros e fujões no Rio de Janeiro imperial. Revista USP, São Paulo, n. 58, p. 104-115, junho/agosto 2003.

FONSECA, Sérgio César da. A infância nos autos de tutela da Comarca de Ribeirão Preto (1889-1917). In: XXI ENCONTRO ESTADUAL DE HISTÓRIA - ANPUH-SP. 2012. Anais... Campinas, 2012a.

- A interiorização da assistência à infância durante a Primeira República: de São Paulo a Ribeirão Preto. Educação em Revista, Belo Horizonte, v. 28, n. 1, p. 79-108, mar. 2012b.

A presença do público e do privado na assistência à infância; semelhanças e diferenças entre São Paulo e Ribeirão Preto (1903-1922). Cadernos de História da Educação, v. 8, n. 1, jan./jun. 2009.

Infância e Disciplina: O Instituto Disciplinar do Tatuapé em São Paulo (18901927). Curitiba: Aos Quatro Ventos, 2007.

; CASTRO, Cíntia Regina Czysz de. O que os jornais contam sobre a menoridade em Ribeirão Preto no início do século XX. Albuquerque: Revista de História, Campo Grande, v. 5, n. 9, p. 133-160, jan./jun. 2013.

FOUCAULT, Michel. A verdade e as formas jurídicas. Tradução de Eduardo Jardim e Roberto Machado. 4. ed. Rio de Janeiro: Nau, 2013.

. Vigiar e punir: nascimento da prisão. Tradução de Raquel Ramalhete. 20. ed. Petrópolis: Editora Vozes, 1999.

FREITAS, Marcos Cezar de; KUHLMANN JR., Moysés. Apresentação. In:

(Orgs.). Os Intelectuais na história da infância. São Paulo: Cortez, 2002. p. 7-9.

GEREMIAS, Patrícia Ramos. Processos de tutela e contratos de soldada: fontes para uma história social do trabalho doméstico infantil. In: $\mathbf{7}^{\mathbf{0}}$ ENCONTRO ESCRAVIDÃO E LIBERDADE NO BRASIL MERIDIONAL, 2015. Anais... Curitiba: UFPR, 2015.

GRINBERG, Keila. A História nos porões dos arquivos judiciários. In: PINSKY, Carla Bassanezi; LUCA, Tania Regina de (Orgs.). O historiador e suas fontes. 1. ed., 3. reimpressão. São Paulo: Contexto, 2013.

LAGES, Jose Antonio Correa. Fundadores: a saga de Manoel Fernandes do Nascimento. Ribeirão Preto: Fundação Instituto do Livro, 2012. (Coleção Nossa História, 6).

LEMOS, Flávia Cristina Silveira. A judicialização da infância: seus impactos na vida da criança e suas famílias. Desidades - Revista Eletrônica de Divulgação Científica da Infância 
e Juventude, Rio de Janeiro, n. 2, ano 2, mar. 2014, p. 25-29. Entrevista concedida à equipe editorial da Revista Desidades. Disponível em: <http://desidades.ufrj.br/wpcontent/uploads/2014/01/2_DESIDADES_mar2014_pt_-11.pdf>. Acesso em: 5 abr. 2016.

MACIEL, Débora Alves; KOERNER, Andrei. Sentidos da judicialização política: duas análises. Lua Nova, n. 57, 2002, p. 113-134.

MARCÍLIO, Maria Luiza. História Social da Criança Abandonada. São Paulo: Hucitec, 1998.

MATTOSO, Kátia de Queirós. O Filho da Escrava (Em Torno da Lei do Ventre Livre). Revista Brasileira de História, São Paulo, v. 8, n. 16, p. 37-77, mar./ago. 1988.

MENENGOTTI-FERREIRA, Débora. Os Parques Infantis de Ribeirão Preto: um estudo sobre sua implantação. 2016. Dissertação (Mestrado)-Faculdade de Filosofia, Ciências e Letras de Ribeirão Preto, Universidade de São Paulo, 2016. Disponível em:

<http://www.teses.usp.br/teses/disponiveis/59/59140/tde-29032016-093744/pt-br.php>. Acesso em: 2 jun. 2016.

MONSMA, Karl. O problema de viés de seleção na pesquisa histórica com fontes judiciais e policiais. História Social, n. 21, 2011.

MORENO, Alessandra Zorzetto. "Vivendo em lares alheios": acolhimento domiciliar, criação e adoção na cidade de São Paulo (1765-1822). 2007. Tese (Doutorado)-Instituto de Filosofia e Ciências Humanas, Universidade Estadual de Campinas, Campinas, 2007.

MOTTA, José Flávio. Escravos daqui, dali e de mais além: o tráfico interno de cativos na expansão cafeeira paulista (Areias, Guaratinguetá, Constituição/Piracicaba e Casa Branca, 1861-1887). São Paulo: Alameda, 2012.

NADER, Paulo. Introdução ao estudo do direito. Rio de Janeiro: Forense, 2008.

OLIVEIRA, Adriane Stoll de. A codificação do Direito. Revista Jus Navigandi, Teresina, ano 7, n. 60, nov. 2002. Disponível em: 〈http://jus.com.br/artigos/3549>. Acesso em: 30 jun. 2015.

OLIVEIRA, Fabiana Luci de; SILVA, Virgínia Ferreira da. Processos judiciais como fonte de dados: poder e interpretação. Sociologias, Porto Alegre, ano 7, n. 13, p. 244-259, jan/jun 2005.

PAZIANI, Rodrigo Ribeiro. Um personagem na Belle Époque ribeirão-pretana: Joaquim Macedo Bittencourt, entre as redes da política e as transformações urbanas na cidade (19021920). Diálogos, DHI/UEM, v. 8, n. 1, p. 169-187, 2004.

Uma cidade à beira da (des)ordem: representações, práticas e experiências urbanas em Ribeirão Preto (1900-1920). In: PERINELLI NETO, Humberto; PAZIANI, Rodrigo Ribeiro; MELLO, Rafael Cardoso de. Nos tempos das cidades: História, Cultura e Modernidade em Ribeirão Preto, SP (1883-1929). Jundiaí: Paco Editorial, 2014, p. 59-100. 
Outras leituras da cidade: experiências urbanas da população de Ribeirão Preto durante a Primeira República. Tempo, Rio de Janeiro, n. 19, p. 175-200, 2005.

PEREIRA, Lafayette Rodrigues. Direitos de família. Rio de Janeiro: B. L. Garnier - Livreiro Editor, 1869. Disponível em: <http://www.lexml.gov.br/urn/urn:lex:br:rede.virtual.bibliotecas :livro:1869;000079114>. Acesso em: 28 set. 2015.

PERINELLI NETO, Humberto; FRANÇA, Jorge Luiz de. Sedução, disciplina e marginalização: a prostituição na Ribeirão Preto da Belle Époque Caipira (1883-1919). Histórica - Revista Eletrônica do Arquivo Público do Estado de São Paulo, n. 38, 2009.

PINHEIRO, Luciana de Araujo. A civilização do Brasil através da infância: propostas e ações voltadas à criança pobre nos anos finais do Império (1879-1889). 2003. Dissertação (Mestrado)-Universidade Federal Fluminense, Niterói, 2003.

PRANDI, Maria Beatriz Ribeiro. A construção da imagem dos parques infantis de Ribeirão Preto das décadas de 1950 e 1960. 2015. Dissertação (Mestrado)-Faculdade de Filosofia, Ciências e Letras de Ribeirão Preto, Universidade de São Paulo, 2015. Disponível em: <http://www.teses.usp.br/teses/disponiveis/59/59140/tde-12092015-112250/pt-br.php>. Acesso em: 15 dez. 2015.

RÊGO, Cristiane. Do fenômeno da judicialização. Acesso à justiça III - Recurso Eletrônico on-line, CONPEDI/UFPB, Florianópolis: CONPEDI, 2014. Disponível em:

<http://publicadireito.com.br/artigos/?cod=2a33b11cfa5f7f31>. Acesso em: 5 abr. 2016.

RIBEIRÃO PRETO. Lei $\mathbf{n}^{\mathbf{0}}$. 80, de 25 de agosto de 1892.

. Lei $\mathbf{n}^{\circ} .88, \mathrm{em}^{\circ}$ de abril de 1889.

Lei Provincial no . 51, de 2 de abril de 1870.

. Lei Provincial $n^{0} .67$, de 12 de abril de 1871.

ROSEMBERG, André; SOUZA, Luís Antônio Francisco de. Notas sobre o uso de documentos judiciais e policiais como fonte de pesquisa histórica. Patrimônio e Memória, UNESP - FCLAs - CEDAP, v. 5, n. 2, p. 159-173, dez. 2009.

SEVERINO, Antônio Joaquim. Metodologia do trabalho científico. 23. ed. São Paulo: Cortez, 2007.

SILVA, De Plácido e. Vocabulário Jurídico. Atualizada por Nagib Slabi Filho e Gláucia Carvalho. 27. ed. Rio de Janeiro: Editora Forense, 2008.

TELLES, Lorena Féres da Silva. Libertas entre sobrados: contratos de trabalho doméstico em São Paulo na derrocada da escravidão. 2011. Dissertação (Mestrado)-Faculdade de Filosofia, Letras e Ciências Humanas, Universidade de São Paulo, 2011.

ZERO, Arethuza Helena. O preço da liberdade: caminhos da infância tutelada - Rio Claro (1871-1888). 2004. Dissertação (Mestrado)-Instituto de Economia, Universidade Estadual de Campinas, Campinas, 2004. 


\section{APÊNDICE}

APÊNDICE A - Lista com as fontes manuscritas encontradas no Arquivo Público e Histórico de Ribeirão Preto “Casa da Memória", no fundo "Processos Antigos", 1 O Ofício Cível, 1872-1917:

1872

1. Ação: Tutella, Requerente: Theophilo Antunes Maciel, Requerido: Manoel Sabino de Araujo, Caixa 41-A.

$\underline{1874}$

2. Ação: Requisição de orphão, Requerente: João Ferreira de Andrade, Requerido: Manoel João, Caixa 41-A.

$\underline{1876}$

3. Ação: Remoção de tutela, Requerente: Francisco Antonio de Moraes, Requeridos: João Rodrigues de Faria, Rita, [ilegível], Adelaine, Maria e João, Caixa 04-A.

$\underline{1886}$

4. Ação: Tutella, Requerente: Manoel Francisco da Silva Onça, Requeridos: Arlindo e Francisco, Caixa 112-A.

5. Ação: Tutella, Requerente: Manoel Victor Nogueira, Requeridos: Virginia, Antonio e Luiz, Caixa 112-A.

$\underline{1888}$

6. Ação: Prestação de contas da tutora Dona Mariana Constança Junqueira das pessoas e bens dos filhos menores, Requerente: Curador Geral de Órfãos Joaquim Moreira de Sousa Dias, Requerida: Maria Constança Junqueira, Caixa 31-A.

7. Ação: Aprehensão do orphão José filho de Catharina de Jesus, Requerente: Peregrino José da Costa, Requerido: José, Caixa 37-A.

8. Ação: Tutella da orphã Guilhermina, filha da ex escrava Catharina, Requerente: Francisco Augusto Pereira do Sacramento, Requerida: Guilhermina, Caixa 31-A. 
9. Ação: Prestação de contas do orphão Vicente, por denúncia do Dr. Curador Geral, Requerente: Curador Geral de Órfãos Joaquim Moreira de Sousa Dias, Requerido: Antonio Ribeiro de Carvalho, Caixa 31-A.

10. Ação: Tutella dos orphãos Oscar, Maria e Cezar, filhos da liberta Balbina, que assigna Domingos Villela de Andrade, Requerente: Anna Clarinda Netto, Requeridos: Oscar, Maria e Cezar, Caixa 39-A.

\section{9}

11. Ação: Tutella da orphã Francisca de 9 annos filha de Luis Italiano auzente [ilegível] incesto, Requerente: Matheus Gomes do Val, Requerida: Francisca, Caixa 36-A.

12. Ação: Aprehensão dos menores Modestos e Francisco, Requerente: Antonio Pereira da Costa, Requeridos: Modesto e Francisco, Caixa: 39-A.

13. Ação: Prestação de contas dos serviçoes do orphão Antero, pelo contratante Fabiano Alvez Barboza e Silva, Requerente: Curador Geral de Órfãos Joaquim Moreira de Sousa Dias, Requerido: Fabiano Alves Barboza e Silva, Caixa 30-A.

14. Ação: Prestação de contas da orphã Francisca, Requerente: Curador Geral de Órfãos Joaquim Moreira de Sousa Dias, Requerido: Manoel de Arruda Estrella, Caixa 30-A.

15. Ação: Tutella do orphão José, Requerente: José da Fonseca Nogueira, Requerido: José, Caixa 39-A.

16. Ação: Regnisição de tutella dos orhpãos Simão e Eufrazia, Requerente: Anna Sabina de Jesus, Requerido: Antonio de Salles Barreto, Caixa 40-A.

17. Ação: Prestação de contas do orphão Firmino filho do finado José Antonio da Silva, Requerente: Juiz de Órfãos Antonio Silveira de Alvarenga, Requerido: Jose Alvez da Silva Sobrinho, Caixa 36-A.

18. Ação: Tutella da orphã Francisca filha da ex escrava Anna que foi de Antonio Mathias da Silva, Requerente: José Ignácio da Costa, Requerida: Francisca, Caixa 35-A.

19. Ação: Prestação de contas dos orphãos Joaquim, Manoel, Anna e Domingos filhos do finados Manoel Paulino Pinto e sua $1^{\mathrm{a}}$ mulher, Requerente: Juiz de Órfãos Antonio Silveira de Alvarenga, Requerido: João Paulino Pinto, Caixa 39-A.

20. Ação: Requisição da tutela das orphãs Prudenciana e Cecilia, Requerente: Joaquim Manoel Nogueira Carvalho, Requeridas: Prudenciana e Cecilia, Caixa 36-A.

21. Ação: Tutela da orphã Maria, filha de Maria Geracina, Requerente: Doutor Barão Delucas, Requerida: Maria, Caixa 30-A. 
22. Ação: Tutella dos orphãos Manoel e Virginia filhos do finado Manoel Moreira de Freitas, Requerente: Augusto da Zimmernan, Requeridos: Manoel e Virginia, Caixa 39A.

23. Ação: Tutella da orphã Maria de 8 annos filha de [ilegível], Requerente: José Idelfonso Pereira, Requerida: Maria, Caixa 39-A.

24. Ação: Tutella da orphã Cecilia, filha de Guilhermina, Requerente: José Luiz de Oliveira, Requerida: Cecilia, Caixa 36-A.

$\underline{1890}$

25. Ação: Soldada do orphão Manoel de 9 annos de idade filho de Agustinha, Requerente: José Ribeiro Bernardes, Requerido: Manoel, Caixa 40-A.

26. Ação: Tutella a soldada do orphao Wenceslan filho de Aureliana de tal, Requerente: Antonio de Magalhães Couto, Requerido: Wenceslan, Caixa 72-A.

27. Ação: Tutella da orphã Anastacia, filha da ex escrava Generoza, Requerente: Luis Monteiro da Silva, Requerida: Anastacia, Caixa 41-A.

28. Ação: Contrato de soldada do menor Pompeo, filho da liberta Maria, Requerente: Adolpho Carneiro de Almeida Maia, Requerido: Pompeo, Caixa 34-A.

29. Ação: Prestação de contas da pessoa da orphã Barbara, Requerente: Juiz de Órfãos Juvenal Malheiros de Souza Alvarenga, Requerido: José Alves de Almeida Silva, Caixa 40-A.

30. Ação: Prestação de contas da soldada do orphão José Luis dos Reis, Requerente: Felisberto Ferreira Gandra, Requerido: José Luis dos Reis, Caixa 40-A.

31. Ação: Contracto de soldada do orphão Vicente, Requerente: Curador Geral de Órfãos Octaviano [ilegível], Requerido: Antonio Ribeiro de Carvalho, Caixa 72-A.

32. Ação: Contrato de soldada do orphão Simão, Requerente: Curador Geral de Órfãos Octaviano [ilegível], Requerido: João Evangelista Nogueira, Caixa 40-A.

33. Ação: Soldada, Requerente: Carlos Arthur Garcia Duarte, Requerido: Martinho, Fundo "Processos Antigos", $1^{\circ}$ Ofício Cível, Caixa 40-A.

34. Ação: Tutella das orphãs filhas do fallecido Augusto Lorena, Requerente: José Martins de Arantes, Requeridos: Miguel Braga e Fonseca, Rachel, Cyrina, Elisa, Laura e Amelia, Caixa 32-A.

35. Ação: Soldada, Requerente: Ernesto Gomes Jardim, Requerido: Agenor, Caixa 72-A.

36. Ação: Locação de serviços, Requerente: Francisco Carlos da Roza, Requerido: Balbino, Caixa 35-A. 
37. Ação: Tutella, Requerente: Lauriano de Souza Ferras, Requeridos: João e Pedro, Caixa 41-A.

38. Ação: Tutela, Requerente: Mariano José Rodrigues, Requerido: João, 30-A.

39. Ação: Tutella, Requerente: José Luiz de Souza, Requerido: José Bertholino, Caixa 35A.

40. Ação: Locação de serviços, Requerente: João Baptista de Aquino, Requerido: Izac, Caixa 40-A.

41. Ação: Locação de serviços, Requerente: Carlos Arthur Garcia Duarte, Requerido: Martinho, Caixa 35-A.

42. Ação: Locação de serviços, Requerente: Felisberto Ferreira Gandra, Requerido: Luciano, Caixa 32-A.

43. Ação: Locação de serviços, Requerente: Manoel Drummond, Requerido: Francisco, Caixa 40-A.

44. Ação: Requerimento de soldada do orphão Antonio de 9 annos filho de Eva Maria de Jesus Requerente: Laurindo Antonio Jacintho, Requerido: Antonio, Caixa 31-A.

45. Ação: Tutella do orphão Manoel, filho dos fallecidos Manoel Moreira de Freitas e mulher, Requerente: José Moreira de Freitas, Requerido: Manoel, Caixa 31-A.

$\underline{1891}$

46. Ação: Requerimento de soldada do menor Antonio de 10 annos de idade filho dos finados Antonio Theodoro da Silva e sua mulher, Requerente: Francisco Ferreira da Silva, Requerido: Antonio, Caixa 35-A.

47. Ação: Requerimento de tutella dos orphãos Antonio, Manoel e Francisca filhos da preta Maria Anna das Dores, Requerente: Claudino Antonio de Carvalho, Requeridos: Antonio, Manoel e Francisca, Caixa 35-A.

48. Ação: Requerimento de tutela dos orphãos Brigida e Manoel filhos da fallecida Custodia liberta, Requerente: Affonso Franco, Requeridos: Brigida e Manoel, Caixa 37-A.

49. Ação: Soldada da orphã Etelvina, filha dos finados Manoel João e sua mulher, Requerente: Luiz Ferreira de Freitas, Requerida: Etelvina, Caixa 35-A.

50. Ação: Aprehensão do orphão Raymundo filho da preta Maria Filipa, Requerente: José Luiz Monteiro da Silveira, Requerido: Raymundo, Caixa 35-A.

51. Ação: Aprehensão do menor Pedro de 5 annos filho de Leopoldina Angela de Azevedo, Requerente: Leopoldina Angela de Azevedo, Requerido: Pedro, Caixa 38-A. 
52. Ação: Requerimento de tutella do orphão Jeronymo filho do finado Antonio Gabriel de Olivera, Requerente: José Vicente Onça, Requerido: Jeronymo, Caixa 42-A.

53. Ação: Tutella do orphão Inocencio de 3 annos de idade filho de Maria Sebastiana, Requerente: Maria Sebastiana, Requerido: Ignacio Rodrigues, Caixa 42-A.

54. Ação: Tutella, Requerente: Manoel da Conte Lucia, Requerido: Julio, Caixa 44-A.

55. Ação: Remoção de tutela, digo soldada, Requerente: Angelo Munis da Silva Ferraz, Requerido: Carlos Arthur Garcia Duarte, Caixa 42-A.

56. Ação: Soldada, Requerente: Joaquim Feliciano Dias da Costa, Requerida: Felisberta, Caixa 42-A.

57. Ação: Soldada, Requerente: Claudino Antonio de Carvalho, Requerida: Tereza, Caixa 33-A.

58. Ação: Apprehensão da menor Victalina, Requerente: José da Fonseca Nogueira, Requeridas: Victalina, Caixa 42-A.

$\underline{1893}$

59. Ação: Tutella, Requerente: João Feliciano Dias da Costa, Requeridos: Luiz, Joaquim, João, Amélia, Nelson, Gilda, [ilegível], Jaci, Atila, Maria e Olga, Caixa 44-A.

60. Ação: Autos de exoneração de tutela, Requerente: Joaquim Manoel Nogueira Carvalho, Requeridas: [ilegível], Philomena, Catharina e Prudenciana, Caixa 43-A.

$\underline{1894}$

61. Ação: Requisição do menor, Requerente: Emilia Bueno Rangel, Requerido: Izac Moreira, Caixa 49-A.

62. Ação: Tutella, Requerente: Pedro Bataglia, Requeridos: Manoel Francisco do Rêgo, João Gonçalves, Evangelina e Roza, Caixa 48-A.

63. Ação: Tutella, Requerente: José Antero de Mello, Requerido: Augusto João Lercadio, Caixa 63-A.

64. Ação: Tutela, Requerente: Manoel Gomes Coelho de Avellar, Requerido: Gilberto, Caixa 44-A.

65. Ação: Tutella, Requerente: Leopoldo Whately, Requerida: Amalia, Caixa 63-A.

66. Ação: Tutella, Requerente: José Antonio de Carvalho, Requerida: Bertolina e Rosaria, Caixa 42-A. 
67. Ação: Auto de Apprehensão, Requerente: Targuinia Maria da Silva, Requerida: Joanna, Caixa 43-A.

$\underline{1895}$

68. Ação: Tutela, Requerente: Hennriqueta Gadina do Amaral, Requerido: Juiz de Direito Eliseu Guilherme Christiano, Caixa 47-A.

69. Ação: Tutela, Requerente: Alexandre Guidugli, Requerida: Virginia, Caixa 47-A.

70. Ação: Tutela, Requerente: Francisco Horta, Requerido: Alfredo, Caixa 52-A.

71. Ação: Tutela, Requerente: Alfredo Rodrigues Jordão, Requeridos: Catharina e João, Caixa 47-A.

$\underline{1896}$

72. Ação: [ilegível], Requerente: Domingos de Magalhães Mattos, Requerido: Antonio Ignacio Nogueira, Caixa 51-A.

73. Ação: Autos de aprehensão de menor, Requerente: Joaquina Paula da Silva e seu marido, Requerida: Emilia, também conhecida como Joana, Caixa123-A.

74. Ação: Tutela, Requerente: Angelo Mazzuco, Requeridos: Luiz e Antonio, Caixa 50-A.

1897

75. Ação: Tutella, Requerente: Curador Geral de Órfãos e Ausentes Pedro [Arlenes] da Silva Junior, Requerido: Gabriel Junqueira, Caixa 122-A.

$\underline{1898}$

76. Ação: Tutella, Requerente: João Barboza, Requerida: Belmira, Caixa 55-A.

77. Ação: Requerimento de entrega do menor Antonio, Requerente: Maria Pedro, Requerido: Antonio, Caixa74-A.

$\underline{1899}$

78. Ação: Provisão de tutela, Requerente: Virginio Menotti, Requerida: Mathilde Menotti, Caixa 87-A.

79. Ação: Apprehensão, Requerente: Antonio Gotar, Requeridos: Antonio, Cristina, Lucia, Giacomo, Quirino e Maria, Caixa 68-A.

80. Ação: Apprehensão de menor, Requerente: José Dolacio Mendes [José Velasco], Requerido: Luiz, Caixa 86-A. 
81. Ação: Termo de tutella, Requerente: Leopoldo Marques da Motta Guimarães, Requerida: Sebastiana, Caixa 71-A.

1900

82. Ação: Tutella, Requerente: Antonio José de Oliveira, Requerida: "uma creança do sexo feminino", Caixa 84-A.

83. Ação: Tutella, Requerente: José Venancio Landim, Requerido: José, Caixa 85-A.

$\underline{1901}$

84. Ação: Tutela, Requerente: Antonio Cabral Muniz, Requeridos: Maria, Emilia, Manoel e Leonor, Caixa 102-A.

85. Ação: [processo sem capa], Requerente: Francisco de Araujo Borges, Requerida: Benedicta, Caixa 102-A.

86. Ação: Destituição de tutoria, Requerente: Mathilde Maria Antonia de Andrade, Requerido: João Teixeira de Carvalho, Caixa 111-A.

$\underline{1902}$

87. Ação: Entrega de menores, Requerente: Benedicta Pires de Abreu, Requeridos: Theodoro, Alfredo, Guiomar, Hiram, Caixa 111-A.

88. Ação: Contracto de soldada, Requerente: Alberto Ferraz de Abreu, Requerido: Sebastião de Godoy, Caixa114-A.

89. Ação: Termo de tutella, Requerente: Curador Geral de Órfãos Mario de Almeida Pires, Requerido: Adelino Norberto da Silva, Caixa 106-A.

90. Ação: Tutoria, Requerente: José Martimiano da Silva, Requerida: Bazilia Lazara dos Santos, Caixa 107-A.

91. Ação: Tutella, Requerente: Antonio Joaquim Pereira, Requerido: Cassiano de Oliveira Pante, Caixa 104-A.

$\underline{1903}$

92. Ação: Tutella, Requerente: Antonio de Andrade, Requeridos: João, Joaquim, Francisco e Guilhermina, Caixa 118-A.

93. Ação: Tutella, Requerente: Laura Maria da Conceição, Requerido: Raulino de Medeiros Marques, Caixa 118-A. 
94. Ação: Tutella, Requerente: Hermenegildo da Silva Victorino, Requerida: Gregoria Bomfim, Caixa 118-A.

95. Ação: Tutella, Requerente: Curador Geral de Órfãos Mario de Almeida Pires, Requerida: Bernadina de Jesus Fraga, Caixa 118-A.

96. Ação: Tutella, Requerente: Curador Geral de Órfãos Mario de Almeida Pires, Requerido: José Lourenço Gonçalves Fraga, Caixa 116-A.

97. Ação: Tutela, Requerente: Curador Geral de Órfãos Mario de Almeida Pires, Requerido: Jacintho Fraga Moreira, Caixa 148-A.

$\underline{1904}$

98. Ação: Tutella, Requerente: Hermenegildo da Silva Victorino, Requerida: Honorina, Caixa 64-A.

99. Ação: Tutella, Requerente: Curador Geral de Órfãos Mario de Almeida Pires, Requerido: Tenente Coronel Gabriel Junqueira, Caixa 128-A.

$\underline{1905}$

100. Ação: Tutoria, Requerente: Angelo Terguiato, Requerida: Amelia Luchitti, Caixa 143A.

101. Ação: Tutella, Requerente: José Henrique Ferraz, Requerido: Edmundo Ferrão, Caixa 132-A.

102. Ação: Tutella do menor João Miranda, Requerente: Francisco Botti, Requerido: João Miranda, Caixa 134-A.

103. Ação: Tutella, Requerente: Victorino Xavier de Lima, Requeridos: Mathusalina, Zoraid e Manoel, Caixa 132-A.

104. Ação: Tutella do menor Francisco, Requerente: Arthur Menegoni, Requerido: Francisco, Caixa 136-A.

105. Ação: Tutella de menor, Requerente: João Baptista da Costa, Requerida: Etelvina Carolina de Lima, Caixa 142-A.

106. Ação: Tutella, Requerente: Adolpho Bianchi, Requerida: Carolina, Caixa 133-A.

107. Ação: Prestação de contas, Requerente: Militão dos Santos Sarayba, Requerida: Maria Gaia Leão, Caixa 132-A.

108. Ação: Entrega de menor, Requerente: Lourenço José Rita, Requerida: Deolinda, Caixa 135-A. 
109. Ação: Justificação e tutella, Requerente: Joaquim Alves da Costa Junior, Requeridos: Barbara, Nelson e Renato, Caixa 136-A.

$\underline{1906}$

110. Ação: Tutella, Requerente: Curador Geral de Órfãos Mario de Almeida Pires, Requerida: Rita Gomes, Caixa 136-A.

111. Ação: Tutella, Requerente: Curador Geral de Órfãos Mario de Almeida Pires, Requerido: Manoel Arantes Nogueira, Caixa 154-A.

112. Ação: Tutella de menores, Requerente: Curador Geral de Órfãos Mario de Almeida Pires, Requeridos: Heloisa, Arthur, Dinorah e Corina, Caixa 146-A.

113. Ação: Tutella, Requerente: Curador Geral de Órfãos Mario de Almeida Pires, Requerido: Manoel Alves Pereira, Caixa 145-A.

114. Ação: [processo sem capa], Requerente: Luzia Massitene, Requerido: Arthur, Caixa 136-A.

115. Ação: Apprehensão de menores, Requerente: João Baptista Lami, Requeridos: Guido, Indea Elverina e Amerope, Caixa 136-A.

116. Ação: Tutella, Requerente: Moyses Fernando do Nascimento, Requerido: Alcides, Caixa 141-A.

1907

117. Ação: Tutoria ad hoc, Requerente: Horacio Corrêa de Carvalho, Requeridos: Manoel, José e Antonino, Caixa 157-A.

118. Ação: Tutella, Requerente: Roza Luchi, Requerido: Jonas Venancio Martins, Caixa 153-A.

119. Ação: Tutella, Requerente: Antonio Bianconi, Requerido: Seylla de Meirelles França, Caixa 81-A.

120. Ação: Prestação de contas, Requerente: Julio Pedro Pontes, Requeridos: Valeriana, Simão e Urbano, Caixa 154-A.

$\underline{1908}$

121. Ação: Tutella, Requerente: Francisco Dionizio dos Santos, Requeridos: Florisbello e Carolina, Caixa 101-A.

122. Ação: Tutella, Requerente: Delegado de Polícia Manoel Innocencio Menna da Costa Filho, Requerida: Rosalina Gaite, Caixa 148-A. 
123. Ação: Tutella da menor Maria José, Requerente: Horacio de Abulquerque Machado, Requerida: Maria José, Caixa 152-A.

124. Ação: Tutella, Requerente: Custodio Vieira da Silva, Requerida: Maria Paulina, Caixa 151-A.

125. Ação: Tutella, Requerente: Curador Geral de Órfãos Mario de Almeida Pires, Requerida: Aurea Borges, Caixa 152-A.

\section{$\underline{1909}$}

126. Ação: Tutella, Requerente: Francisco Lourenço, Requerido: Victorino dos Santos, Caixa 158-A.

127. Ação: Tutella, Requerente: José da Silveira Campos, Requerida: Benedicta, Caixa 158-A.

128. Ação: Tutella, Requerente: José Luis Pereira, Requerida: Roza, Caixa 158-A.

\section{$\underline{1910}$}

129. Ação: Prestação de contas, Requerente: Julio Pedro Pontes, Requeridos: Urbano Bomfim e outros, Caixa 162-A.

130. Ação: Prestação de contas, Requerente: Julio Pedro Pontes, Requeridos: Urbano Bomfim e outros, Caixa 167-A.

131. Ação: Tutella, Requerente: Maria Chistina Barbosa, Requerido: Christiano [Mamede] de Freitas, Caixa 162-A.

132. Ação: Tutella, Requerente: João Fabrício de Alcantra, Requerida: Maria, Caixa 162A.

133. Ação: Tutella, Requerente: Aristides de Oliveira, Requerido: Manoel, Caixa 174-A.

134. Ação: Tutella com renuncia do patrio poder, Requerente: Chrispiriano de Lima, Requerido: Francisco Vincelli, Caixa 162-A.

135. Ação: Tutella, Requerente: Crossi Severio, Requerido: Belmiro da Silveira Franco, Caixa 161-A.

136. Ação: Tutella, Requerente: Delegado de Polícia Joaquim [Machado da Teixeira], Requerida: Maria Carmissa, Caixa 162-A.

137. Ação: Tutella, Requerente: Francisco Junqueira, Requeridos: Virginia e Brazil, Caixa 159-A.

138. Ação: Tutella, Requerente: Delegado de Polícia Joaquim [Machado da Teixeira], Requerido: Antonio Tiburio de Sousa Oliveira, Caixa 161-A. 
139. Ação: Aprehensão de menor, Requerente: José Manoel Fernandes, Requerida: Maria Delphina, Caixa 162-A.

$\underline{1911}$

140. Ação: Tutella, Requerente: Arlindo Machado de Oliveira, Requerida: Antonia, Caixa 168-A.

141. Ação: Tutella, Requerente: Simeão dos Santos Bomfim, Requerido: Julio Pedro Pontes, Caixa 168-A.

142. Ação: Tutella, Requerente: Curador Geral de Órfãos Mario de Almeida Pires, Requerido: Matheus Gomes do Val, Caixa 166-A.

143. Ação: Tutella ad hoc, Requerente: Delegado de Polícia [A. Alvador Pires], Requerida: Maria Thereza, Caixa 166-A.

144. Ação: Tutella, Requerente: Sebastião Lopes, Requerida: Maria Augusta de Oliveira, Caixa 168-A.

145. Ação: Tutella, Requerente: Delegado de Polícia Leon Grandjean, Requerido: José Lourenço Bellieni, Caixa 168-A.

$\underline{1912}$

146. Ação: Tutela, Requerente: João Augusto da Rocha Lima, Requerida: America, Caixa 172-A.

147. Ação: Tutella, Requerente: Sabino Annunciata, Requerida: Philomena Mensagno, Caixa 172-A.

148. Ação: Tutela do menor, Requerente: Joaquim Vieira de Souza Filho, Requerido: Cristiano Orlando, Caixa 172-A.

\section{3}

149. Ação: Tutella, Requerente: Francisco Macedo de Mattos, Requerida: Joaquina Mendes Vianna, Caixa 179-A.

150. Ação: Tutella do menor Candido Vianna, Requerente: Curador Geral de Órfãos Luciano Esteves dos Santos Junior, Requerido: Reginaldo da Silva Barros, Caixa 179A.

151. Ação: Tutella da menor, Requerente: Curador Geral de Órfãos Luciano Esteves dos Santos Junior, Requerido: Felinto Pereira, Caixa 221-A. 


\section{$\underline{1914}$}

152. Ação: Tutella da menor, Requerente: José Alvarez Rodrigues, Requerida: Leoncia Alvarez Magro, Caixa 180-A.

153. Ação: Tutoria da menor, Requerente: Delegado de Polícia Joaquim [Machado da Teixeira], Requerida: Lódina Violeta, Caixa 184-A.

154. Ação: Tutella, Requerente: Gabriel Monteiro de Barros, Requerida: Alvina Albertina, Caixa 183-A.

155. Ação: Tutella, Requerente: Luiz Chiericato, Requerida: Maria, Caixa 180-A.

156. Ação: [processo sem capa], Requerente: Julio Pedro Pontes, Requeridos: Urbano e Simeão dos Santos Bomfim, Caixa 182-A.

157. Ação: Tutella, Requerente: Curador Geral de Órfãos Luciano Esteves dos Santos Junior, Requerido: Anthero Estanislau de Miranda, Caixa 180-A.

158. Ação: Tutella, Requerente: Curador Geral de Órfãos Luciano Esteves dos Santos Junior, Requerido: Ubrico Nieri, Caixa 180-A.

159. Ação: Nomeação de tutor ad hoc, Requerente: Curador Geral de Órfãos Luciano Esteves dos Santos Junior, Requerido: Antonio Eugenio de Moraes, Caixa 180-A.

\section{$\underline{1915}$}

160. Ação: [processo sem capa], Requerente: Julio Pedro Pontes, Requerido: Urbano dos Santos Bomfim, Caixa 186-A.

161. Ação: Tutella, Requerente: Curador Geral de Órfãos Manoel da Silva Carneiro, Requerido: Benjamin Cintra, Caixa 189-A.

162. Ação: Tutella, Requerente: Curador Geral de Órfãos Luciano Esteves dos Santos Junior Requerido: Leão da Motta Pinheiro, Caixa 187-A.

\section{6}

163. Ação: Prestação de contas, Requerente: Matheus Gomes do Val, Requeridos: Olga, Hermantina e Oswaldo, Caixa 166-A.

164. Ação: Tutoria do menor, Requerente: Curador Geral de Órfãos Manoel da Silva Carneiro, Requerido: Carlos Americo Brandão, Caixa 191-A.

165. Ação: Tutoria da menor, Requerente: Curador Geral de Órfãos Manoel da Silva Carneiro, Requerido: Ildefonso de Camargo, Caixa 200-A. 
166. Ação: Prestação de contas, Requerente: Curador Geral de Órfãos Manoel da Silva Carneiro, Requerido: José Alves de Almeida Macuco, Caixa 201-A.

167. Ação: Prestação de contas, Requerente: Curador Geral de Órfãos Manoel da Silva Carneiro, Requerido: Raulino de Medeiros Marques, Caixa 118-A.

168. Ação: Tutella, Requerente: Antonio Diederichsen, Requerido: João, Caixa 193-A.

169. Ação: Tutella, Requerente: Curador Geral de Órfãos Manoel da Silva Carneiro, Requerido: Saveiro Andreoli, Caixa 201-A.

170. Ação: Prestação de contas, Requerente: Urbano dos Santos Bomfim, Requerido: Julio Pedro Pontes, Caixa 199-A.

171. Ação: Tutella, Requerente: Thomaz Leme, Requerida: Zulmira, Caixa 201-A. 
ANEXOS

ANEXO A - Capa do primeiro processo judicial referente à tutela produzido em Ribeirão Preto (SP)

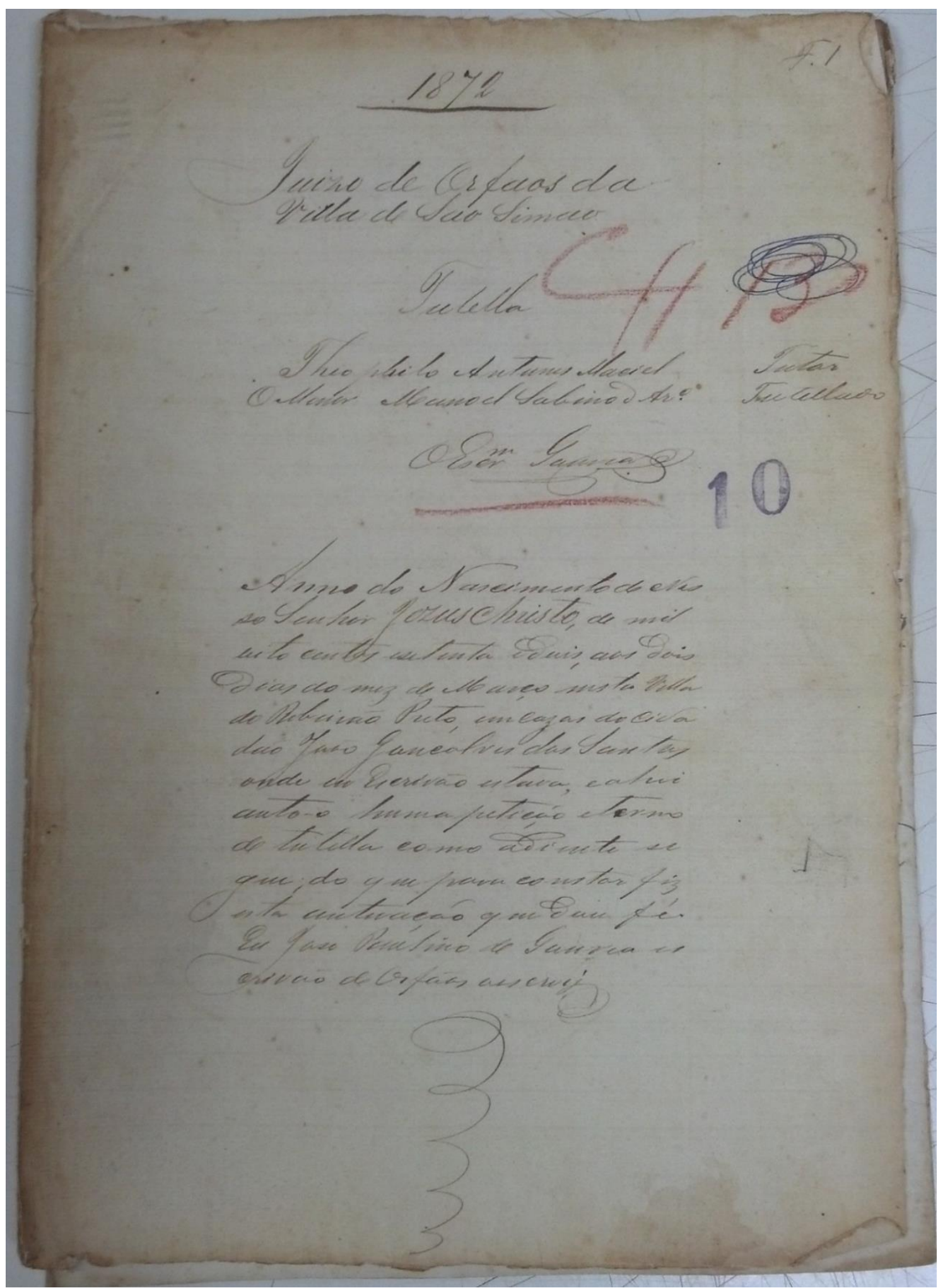


ANEXO B - Folha 1 do primeiro processo judicial referente à tutela produzido em Ribeirão Preto (SP)

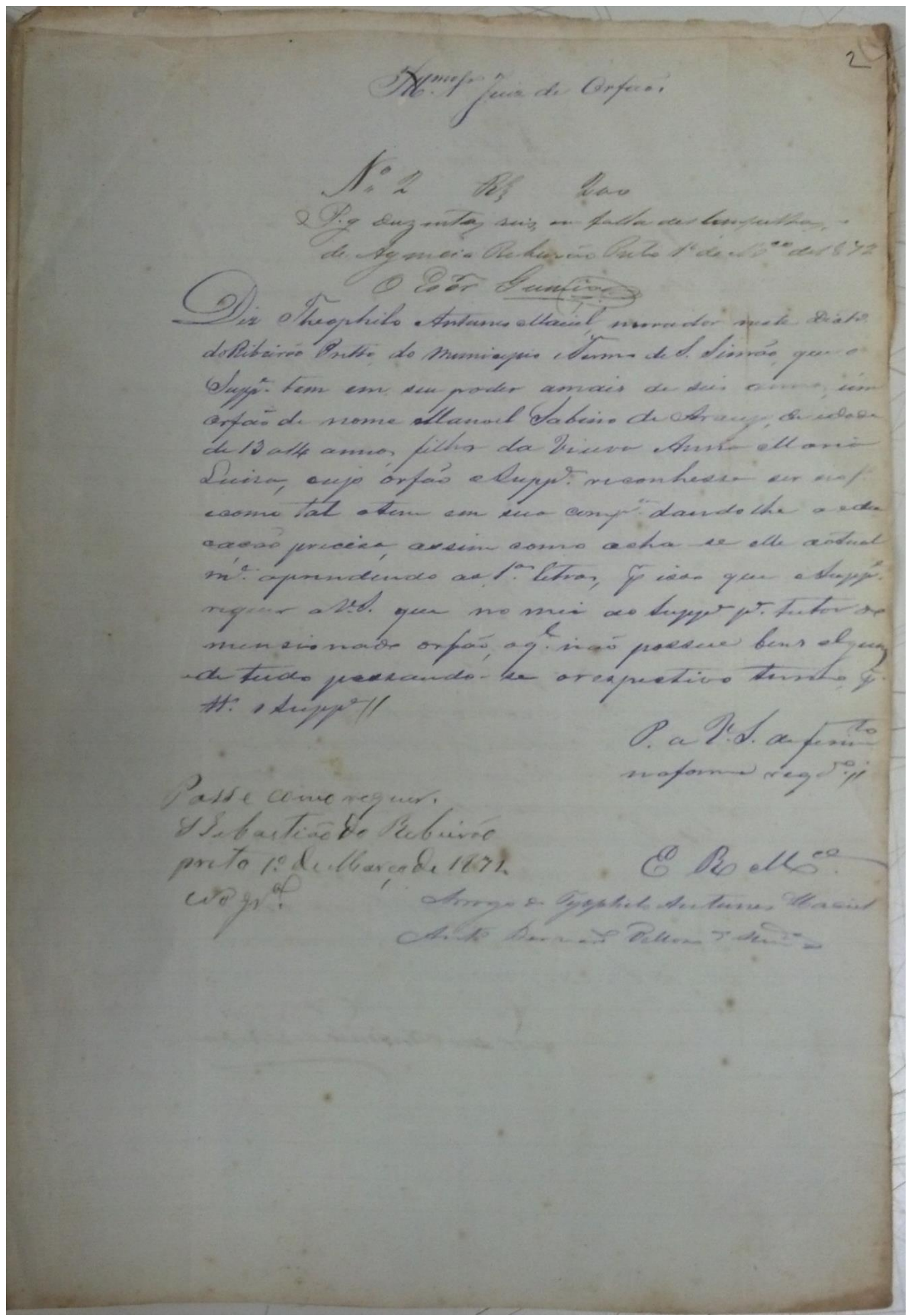


ANEXO C - Folha 2 do primeiro processo judicial referente à tutela produzido em Ribeirão Preto (SP)

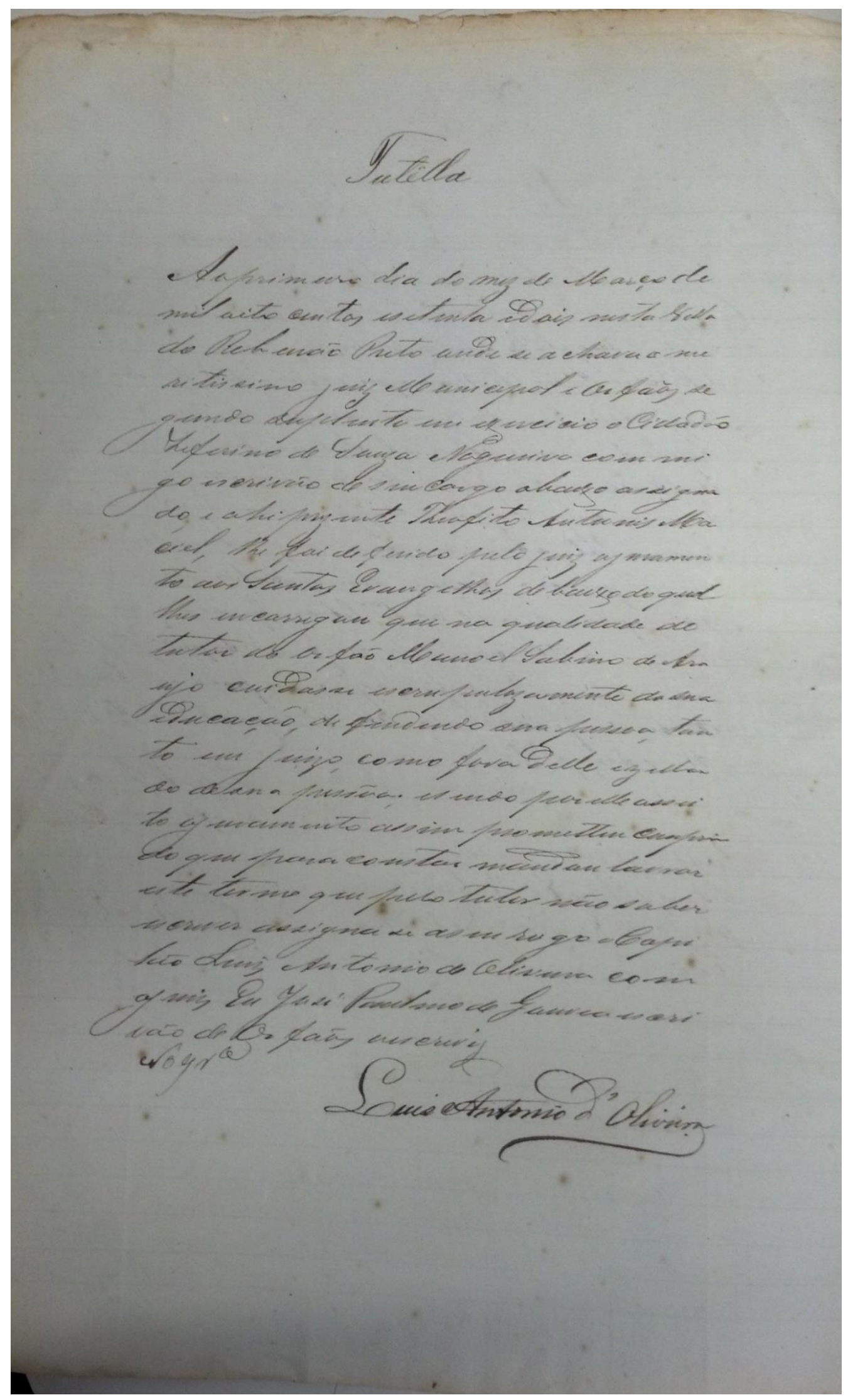




\section{ANEXO D - Solicitação enviada ao Fórum de Ribeirão Preto para autorização de consulta ao acervo de processos judiciais sob custódia do Arquivo Público e Histórico de Ribeirão Preto para fins de trabalho acadêmico}

Ribeirão Preto, 26 de março de 2014.

Exmo. Sr. Dr. Paulo César Gentile

DD. Juiz de Direito

Diretor do Fórum de Ribeirão Preto

Rua Alice Além Saad, 1010

CEP: $14056-570$

Excelentíssimo Senhor Juiz,

Venho por meio desta solicitar autorização para consultar/pesquisar o acervo de processos judiciais sob custódia do Arquivo Público e Histórico de Ribeirão Preto, para fins de trabalho acadêmico (mestrado).

Esclareço que fui aluna do curso de Pedagogia da Faculdade de Filosofia, Ciências e Letras de Ribeirão preto, da Universidade de São Paulo e pretendo retornar a esta mesma instituição para iniciar uma pós-graduação, no nível de Mestrado, sob a orientação do Prof. Dr. Sérgio César da Fonseca.

Sem mais para o momento, antecipo os meus agradecimentos.

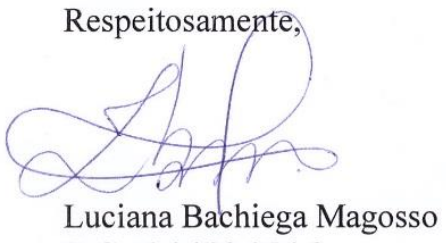

Cidade: Ribeirão Preto 


\section{ANEXO E - Autorização para consulta ao acervo do Fórum de Ribeirão Preto disposto no Arquivo Público e Histórico de Ribeirão Preto para fins de trabalho acadêmico (Oficio $\left.n^{0} .033 / 2014-j \mathrm{jcg}\right)$}

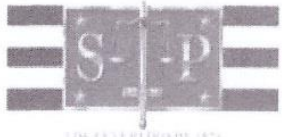

OFÍCIO n. ${ }^{\circ} 033 / 2014-\mathrm{jcg}$
PODER JUDICIÁRIO TRIBUNAL DE JUSTICA DO ESTADO DE SÃO PAULO COMARCA DE RIBEIRÁO PRETO DIRETORIA DE ADMIVISTRACÃO GERAH Rua Alice Alem Saadi, $n^{0} 1010-1^{\circ}$ andar - Nova Ribeirânid CEP 14096570 - Fone: (16) 36290004 ramal 620016202

Ribeirão Preto, 27 de março de 2014.

Ilustrissima Senhora:

Tem o presente a finalidade de informar a Vossa Senhoria que autorizo a aluna LUCIANA BACHIEGA MAGOSSO, RG $\mathbf{n}^{\circ}$ PEDAGOGA, pleiteando acesso ao processo seletivo de Mestrado junto a Universidade de São Paulo - USP / Ribeirão Preto, a consultar o acervo disposto no Arquivo Público e Histórico de Ribeirão Preto, para fins de Trabalho de Acadêmico, ressalvados os casos de segredo de justiça.

Aproveito a oportunidade para renovar a Vossa Senhoria meus protestos de consideração.

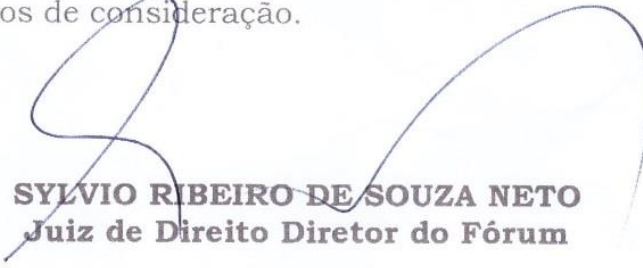

Ilma. Senhora LILIAN RODRIGUES DE OLIVEIRA ROSA

Chefe da Divisão de Preserv. do Patrim. Histórico e Cultural Rua José da Silva, 915 - Jd. Paulista

Ribeirão Preto - SP 